\title{
The Monterey Submarine Canyon, California Moored Array Data Report
}

\author{
by \\ Kaye Kinoshita ${ }^{1}$ and Marlene Noble ${ }^{1}$
}

Project Scientists:

Dr. Cynthia H. Pilskaln ${ }^{2}$

Dr. Leslie K. Rosenfeld ${ }^{3}$

Dr. Franklin B. Schwing ${ }^{4}$

Open-File Report 95-838

This report is preliminary and has not been reviewed for conformity with U.S. Geological Survey editorial standards or with the North American Stratigraphic Code. Any use of trade, product, or firm names is for descriptive purposes only and does not imply endorsement by the U.S. Government

\footnotetext{
${ }^{1}$ U.S. Geological Survey, Menlo Park, California 94025

${ }^{2}$ University of Maine, Orono, Maine 04469

${ }^{3}$ Monterey Bay Aquarium Research Institute, Pacific Grove, California 93950

${ }^{4}$ National Marine Fisheries Services, Monterey, California 93942
} 


\section{Table of Contents}

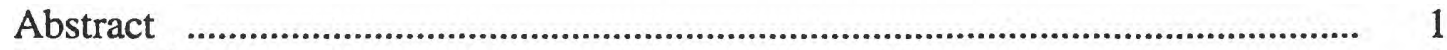

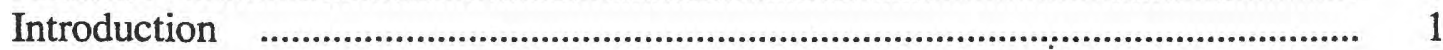

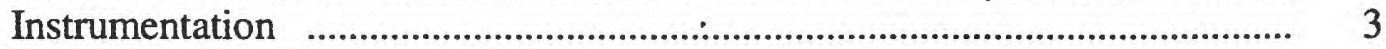

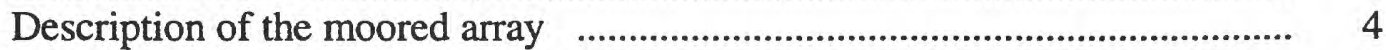

Data sets and statistical methods ……………………................................. 6

Moored current observations $\quad$.......................................................................... 6

Moored temperature, salinity, attenuation and transmission observations $\quad \ldots \quad 10$

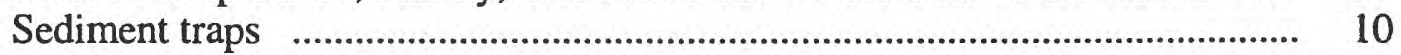

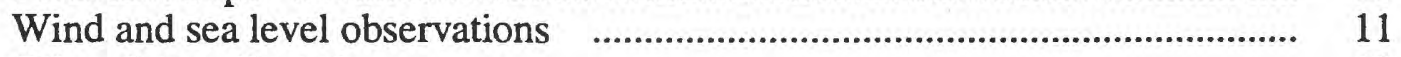

Other data collected $\quad$................................................................................... 13

Acknowledgements ............................................................................. 14

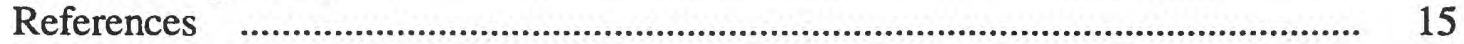

\section{Appendix A - Tables}

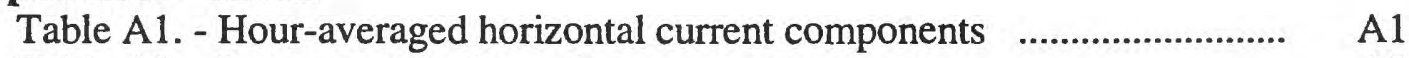

Table A2. - Lowpassed horizontal current components ………………........ A2

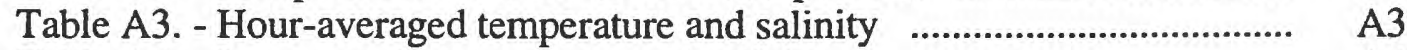

Table A4. - Lowpassed temperature and salinity ……….............................. A4

Table A5. - Diurnal tidal currents …........................................................ A5

Table A6. - Semi-diurnal tidal currents …................................................... A6

\section{Appendix B - Time series plots}

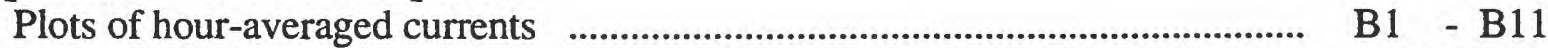

Plots of subtidal currents ………........................................................... B12 - B21

\section{Appendix C - Subtidal current vectors}

Plots of subtidal current vectors

$\mathrm{C} 1-\mathrm{C} 5$

\section{Apppendix D. - Variance-conserving auto spectra currents}

Table D1. - Dates \& piece lengths used for current spectral plots $\quad$.................... D1

Variance-conserving auto spectra currents

D2 - D13

\section{Appendix E - Temperature, salinity and transmission}

Plots of hour-averaged temperature

E1 - E6

Plots of lowpassed temperature

E7 - E12

Plots of hour-averaged salinity

$\mathrm{E} 13-\mathrm{E} 16$

Plots of lowpassed salinity

$\mathrm{E} 17$ - E20

Plots of hour-averaged transmission

E21 - E24 


\section{Appendix F - Wind and sea level}

Table F1. - Dates \& piece length for wind \& sea lev spect plots ................... F1

Table F2. - Sea level tidal components ....................................................... F1

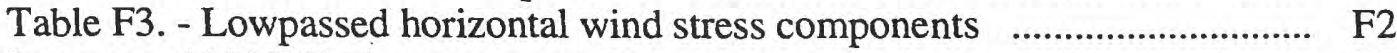

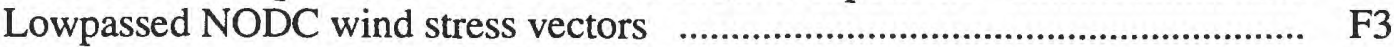

Variance-conserving auto spectra winds

Plots of subtidal synthetic subsurface pressure .................................... F7

Variance-conserving auto spectra subtidal synthetic subsurface pressure $\quad \ldots . . . . \quad$ F8

\section{Appendix G - Additional data for Monterey Fan mooring 1994-1995}

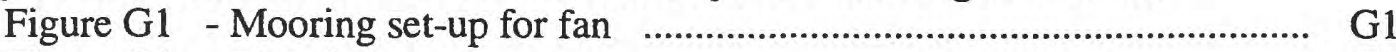

Figure G2. - Timelines .................................................................... G2

Table G1. - Data available .................................................................... G3

Table G2. - Hour-averaged horizontal current components ....................... G4

Table G3. - Lowpassed horizontal currentcomponents $\quad$.............................. G4

Table G4. - Hour-averaged temperature and salinity $\quad$..................................... G5

Table G5. - Lowpassed temperature and salinity ....................................... G5

Table G6. - Diurnal tidal currents ............................................................. G6

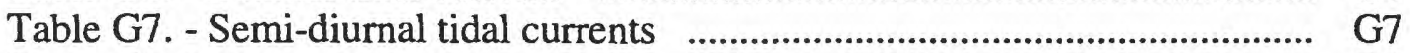

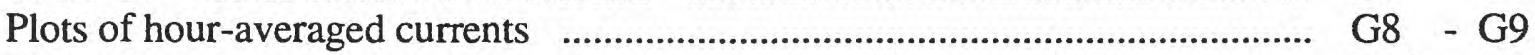

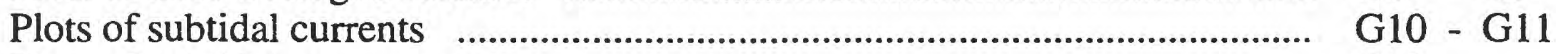

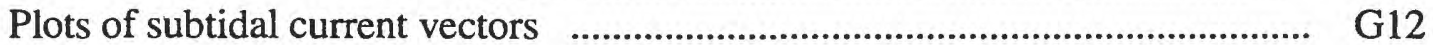

Table G8. - Dates and piece lengths used for current spectral plots ............... G13

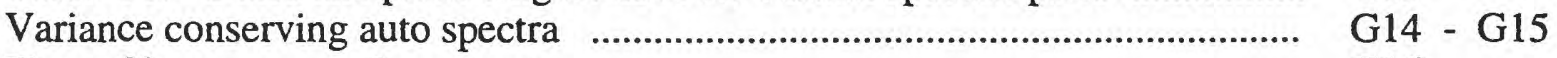

Plots of hour-averaged temperature ........................................................ G16

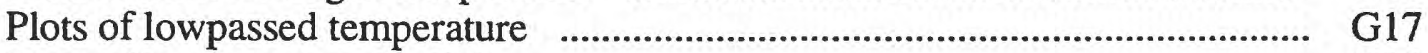

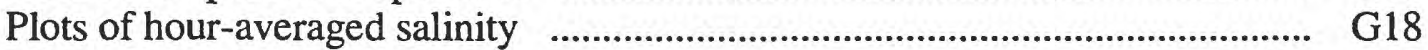

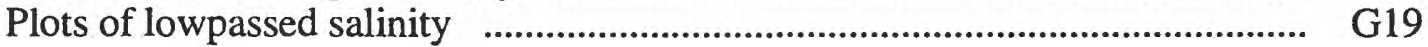




\section{ABSTRACT}

In August, 1993, a program was begun to study the mechanisms that govern the circulation within and the transport of sediment and water through Monterey Submarine Canyon. This is a very large, deep submarine canyon off central California that incises the continental margin from the outer slope to close to the coastline. The research plan was also designed to study the interactions among circulation patterns above, within, and past the mouth of the canyon. As part of the program, six moorings that measured current, temperature, salinity and water clarity were deployed simultaneously for one year at individual sites in Monterey Canyon. Sediment traps were attached to 5 of the 6 moorings. On recovery, the mooring at the deepest site only was replaced. The additional mooring collected information from August 1994 to May 1995. This report describes and depicts the data that were collected from the larger moored array and the single, redeployed mooring. The main section focuses on the moored array data, plus wind and sea level records, collected between August 1993 and August 1994. The subsequent data collected at the deepest site is included in a separate appendix.

\section{INTRODUCTION}

The mechanisms that govern the circulation within and the transport of sediment and bottom water through submarine canyons have long been among the more complex and enigmatic issues in marine ecosystems because monitoring these processes is difficult. In August, 1993, a yearlong program involving the U.S. Geological Survey (USGS), Monterey Bay Aquarium Research Institute (MBARI), National Oceanic and Atmospheric Administration (NOAA) and University of Maine was begun to study these mechanisms in Monterey Canyon. As part of this program, an array of moorings was deployed in Monterey Canyon, California (Figure 1). Monterey is an interesting canyon in that it is large enough to have a great variety of physical dimensions along its en- tire length. In places, the size of the internal radius of deformation suggests that the canyon is dynamically narrow; at others it is dynamically wide. Analytical models of flows in canyons by Klinck (1989) and Hughes et al. (1990) suggest the dynamic width is a critical parameter in determining the nature of the circulation within a canyon and the effect of the canyon on overlying currents. In addition, it is known that sediment-transport events occur in the canyon and that the canyon supports a highly productive biological community

It was necessary to undertake a study to gather new information because the historical data sets that describe circulation and sediment transport in Monterey Canyon are scarce. Previous measurements of currents within the canyon consist of a few records from moorings deployed for a short period of time (Shepard et al., 1979), some microstructure observations (Itsweire and Osborn, 1988) and turbulence measurements (Lueck and Osborn, 1985). The current observations were too limited to provide a basis for a clear understanding of circulation within and near the canyon. Koehler (1990) has applied a simple 2-layer numerical model to the region. When he forces the outer boundary of his model with geostrophic flow measured during May, 1988, a cyclonic flow develops in the lower layer that is confined to the outer reaches of the canyon. A variety of investigations have shown that sediment transport in Monterey Canyon is a very active process. Shepard et al. (1979) and others suggested that internal tides are strong enough to transport sediment in the canyon. During the recent Loma Prieta earthquake, transponders deployed in the canyon moved $2 \mathrm{~km}$ down canyon (Garfield et al., 1994).

In order to gather the necessary information to describe circulation and sediment transport patterns in Monterey Canyon, 6 moorings were deployed at 3 cross-canyon sections (Figure 1). One cross-section is thought to be dynamically "narrow" (sites NN and NA), one dynamically "wide" (WN, WA, and WS) and one is near the "fan" (F) section of the canyon. Seven sediment traps were mounted on 5 of these moorings. In November, 1994 a conductivity, temperature and 

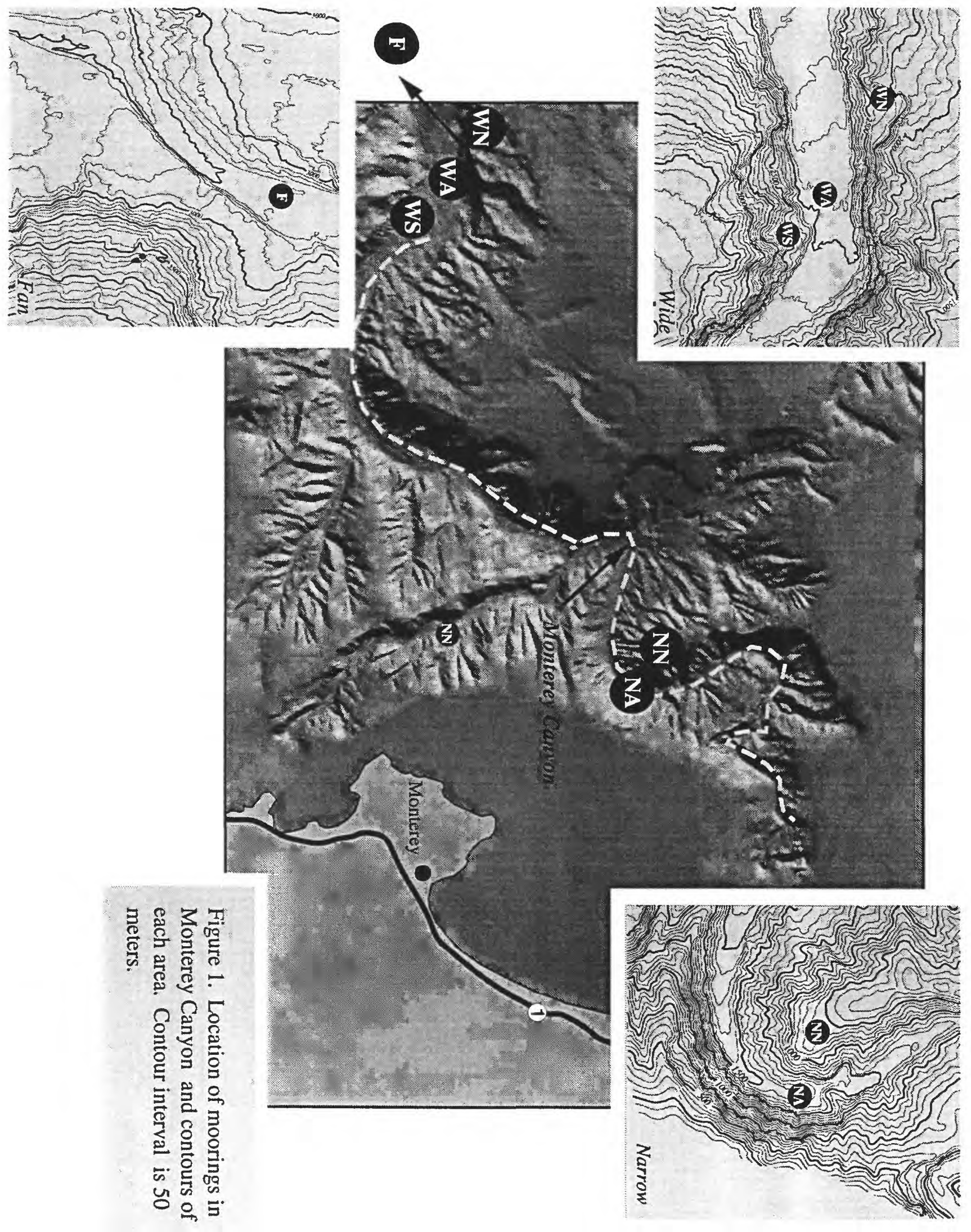
depth (CTD) survey was conducted and 5 box cores were taken at different sites within the canyon Several other CTD surveys were conducted in the vicinity throughout the time period that the moorings were in place.

This report describes and depicts the data collected by the moored array. A detailed description of the moored array and the instruments on each mooring is given in the next section. The principal data collected in this field program include records of current direction and velocity, temperature, salinity and water clarity measured at several different sites in the canyon. The subsequent sections of the report list the statistical quantities of the entire data set and depict the characteristics of the hour-averaged and subtidal records. Because tidal currents are a major feature in submarine canyons,. the amplitudes of the diurnal and semidiurnal tides are listed in detail at each measurement site

\section{Instrumentation}

The exact design of each mooring was specific to each measurement site (Table 1), although there were many features common to each one
(Figure 2a, b, c). All instruments at a site were attached to a single mooring. Either a single or dual acoustic release package was used to connect the mooring to the anchor.

The type of current meter used (Table 1) was a EG\&G vector-averaging current meters (VACM). A VTCT is also referred to in this report. The VTCT is a vector averaging current meter with a transmissometer attached to it to record transmission data. The VACM is specifically designed to measure currents even when oscillatory currents from large surface waves are present. A detailed description of the design and measurement characteristics is provided by McCullough, 1975, Mero, 1982 and Beardsley et al., 1987. The meter measured the average current direction and speed every 15 minutes.

To measure water clarity (transmission), Sea Tech transmissometers with a $25 \mathrm{~cm}$ path length were used. The data were recorded on a Sea Cat data logger or a modified VACM data logger. The clear water reading for each transmissometer was recorded before each deployment. The relation between the transmissometer reading and the amount of material resuspended in the water column was derived using the natural sediment at the

\begin{tabular}{|c|c|c|c|c|c|c|c|c|c|c|}
\hline \multirow[b]{2}{*}{ Site } & \multirow[b]{2}{*}{ Moaring } & \multirow{2}{*}{$\begin{array}{l}\text { Water } \\
\text { Depth } \\
(\mathrm{m})\end{array}$} & \multirow{2}{*}{$\begin{array}{c}\text { Start } \\
\text { Time } \\
(\mathrm{M} / \mathrm{D} / \mathrm{Y}) \\
\end{array}$} & \multirow{2}{*}{$\begin{array}{c}\text { Stop } \\
\text { Time } \\
\text { (M/D/Y }\end{array}$} & \multirow[b]{2}{*}{ Instrument } & \multicolumn{2}{|c|}{ Position } & \multirow{2}{*}{$\begin{array}{l}\text { Sensor } \\
\text { Depth } \\
\text { (m) }\end{array}$} & \multirow[b]{2}{*}{$\begin{array}{l}\text { Data } \\
\text { Type }\end{array}$} & \multirow[b]{2}{*}{$\begin{array}{c}\text { Sample Interval } \\
\text { (minutes) }\end{array}$} \\
\hline & & & & & & Latitude & Longitude & & & \\
\hline NN & $422-1$ & 806 & $08 / 03 / 93$ & $08 / 17 / 94$ & $\overline{\text { VACM }}$ & $3643.40 \mathrm{~N}$ & $12202.10 \mathrm{~W}$ & 746 & $\overline{T, C^{*}}$ & 15 \\
\hline NA & $423-1$ & 1450 & 08/03/93 & $08 / 17 / 94$ & VTCT & $3643.17 \mathrm{~N}$ & $12200.75 \mathrm{~W}$ & 770 & C.T,S,TR & 15 \\
\hline NA & $423-2$ & 1450 & $08 / 03 / 93$ & $08 / 17 / 94$ & VACM & $3643.17 \mathrm{~N}$ & $12200.75 \mathrm{~W}$ & 1250 & C, $\mathrm{T}$ & 15 \\
\hline NA & $423-3$ & 1450 & $08 / 03 / 93$ & $08 / 17 / 94$ & VTCT & $3643.17 \mathrm{~N}$ & $12200.75 \mathrm{~W}$ & 1350 & C,T,A,S,TR & 15 \\
\hline WN & $424-1$ & 2420 & 08/03/93 & $08 / 17 / 94$ & VTCT & $3638.00 \mathrm{~N}$ & $12224.77 \mathrm{~W}$ & 1960 & C,T,A,S,TR & 15 \\
\hline WN & $424-2$ & 2420 & 08/03/93 & $08 / 17 / 94$ & VTCT & $3638.00 \mathrm{~N}$ & $12224.77 \mathrm{~W}$ & 2320 & $\mathrm{C}, \mathrm{T}, \mathrm{A}, \mathrm{S}, \mathrm{TR}$ & 15 \\
\hline ws & $425-1$ & 2560 & $08 / 03 / 93$ & 08/18/94 & VTCT & $3635.70 \mathrm{~N}$ & $12220.90 \mathrm{~W}$ & 1990 & C,T,A,S & 15 \\
\hline ws & $425-2$ & 2560 & $08 / 03 / 93$ & $08 / 18 / 94$ & VACM & $3635.70 \mathrm{~N}$ & $12220.90 \mathrm{~W}$ & 2350 & $\mathrm{C}, \mathrm{T}$ & 15 \\
\hline WA & $426-1$ & 2837 & 08/03/93 & 08/18/94 & VACM & $3636.47 \mathrm{~N}$ & $12222.13 \mathrm{~W}$ & 1612 & $\mathrm{C}, \mathrm{T}$ & 15 \\
\hline WA & $426-2$ & 2837 & $08 / 03 / 93$ & 08/18/94 & VTCT & $3636.47 \mathrm{~N}$ & $12222.13 \mathrm{~W}$ & 1982 & C,T,A,S,TR & 15 \\
\hline WA & $426-3$ & 2837 & $08 / 03 / 93$ & 08/18/94 & VACM & $3636.47 \mathrm{~N}$ & $12222.13 \mathrm{~W}$ & 2342 & $\mathrm{C}, \mathrm{T}$ & 15 \\
\hline WA & 4264 & 2837 & 08/03/93 & $08 / 18 / 94$ & VACM & $3636.47 \mathrm{~N}$ & $12222.13 \mathrm{~W}$ & 2737 & $\mathrm{C}, \mathrm{T}$ & 15 \\
\hline F & $427-1$ & 3223 & $08 / 05 / 93$ & $08 / 20 / 94$ & VACM & $3627.47 \mathrm{~N}$ & $12237.53 \mathrm{~W}$ & 3213 & C.T & $\begin{array}{l}15 \\
15\end{array}$ \\
\hline
\end{tabular}

Table 1.- Data availability for all moorings for 1993-1994.

VACM = Vector averaging curnent meter (measures current and temperature)

VTCT = Vector averaging current meter (messures current, temperature and transmission)
$A=$ attenuation
$S=$ salinity
$T R=$ transmission

$C=$ current data

$T=$ sea temperature

$C^{*}=$ rotor speed only 
site and the calibration procedures described in Moody, et al., 1987. The sample rate was 15 minutes (Table 1).

Sea Bird conductivity cells were used to obtain the conductivity measurements. The data were recorded on either a Sea Cat data logger or a modified VACM data logger. Each conductivity cell was calibrated by the manufacturer's specifications before each deployment. The sample rate was the same as for the current meter (Table 1).

Water temperature was measured with temperature sensors installed in the VACM's and VTCT's or Sea Bird data logger. All temperature sensors were calibrated by the manufacturer's specifications before deployment. The sample rate was the same as for the current meter (Table 1).
A $0.5 \mathrm{~m}$ diameter Anderson sediment trap was used to collect a record of resuspended sediment at each site. An intervalometer that dispenses discrete layers of Teflon at a specified time interval were used in many of the sediment traps to generate a time base for the resuspended sediment.

\section{Description of the moored array}

The comprehensive field program consisted of several elements. An array of 6 moorings was deployed at 3 cross-sections in Monterey Canyon (Figure 1) in August 1993. The moorings at each site measured current, temperature, salinity and water clarity at several locations in the water column (Figures 1, 3a and $3 \mathrm{~b}$ ). The moorings also

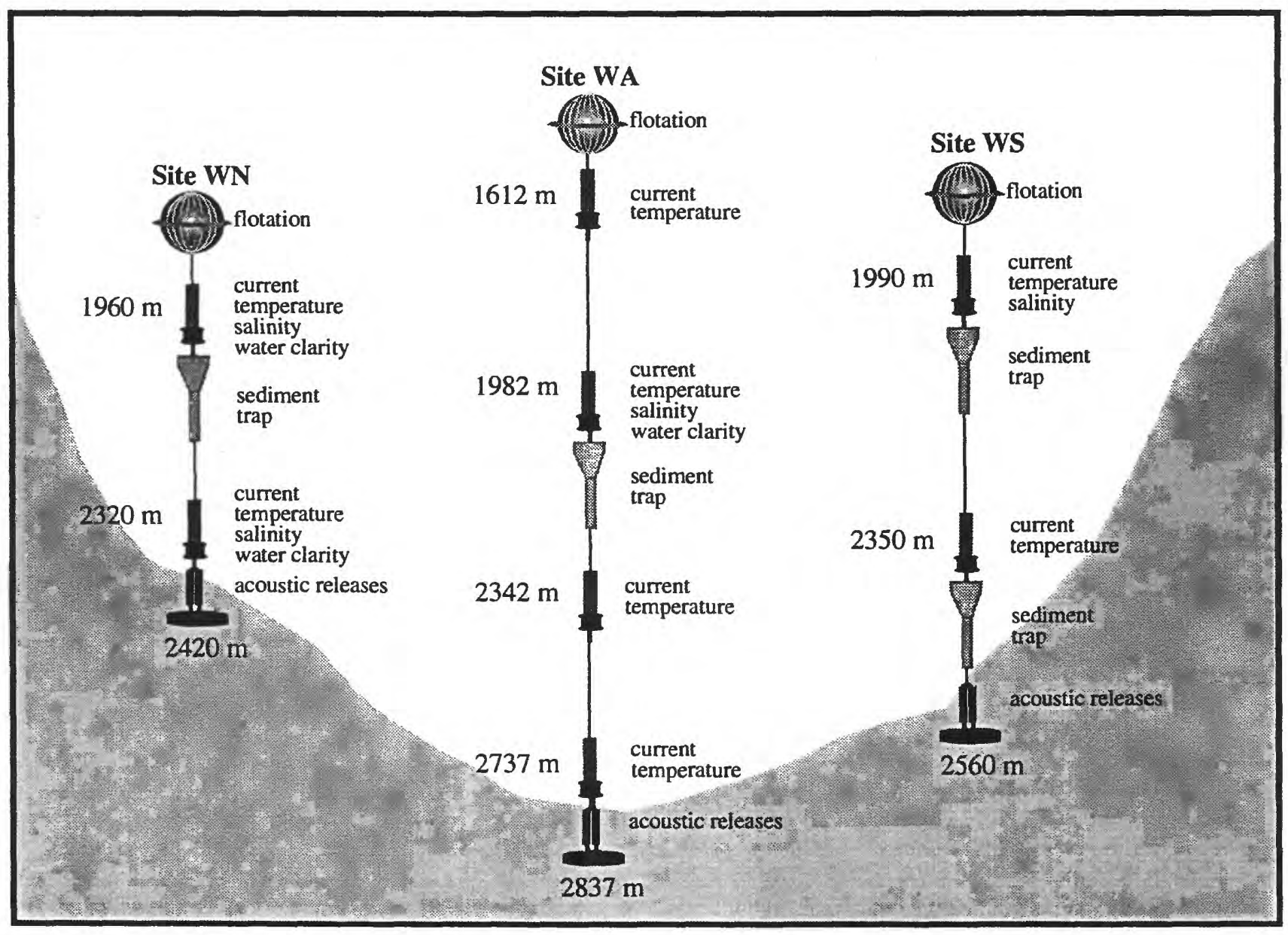

Figure 2a. Cross section view of mooring set-up at "wide" section of Monterey Canyon. 


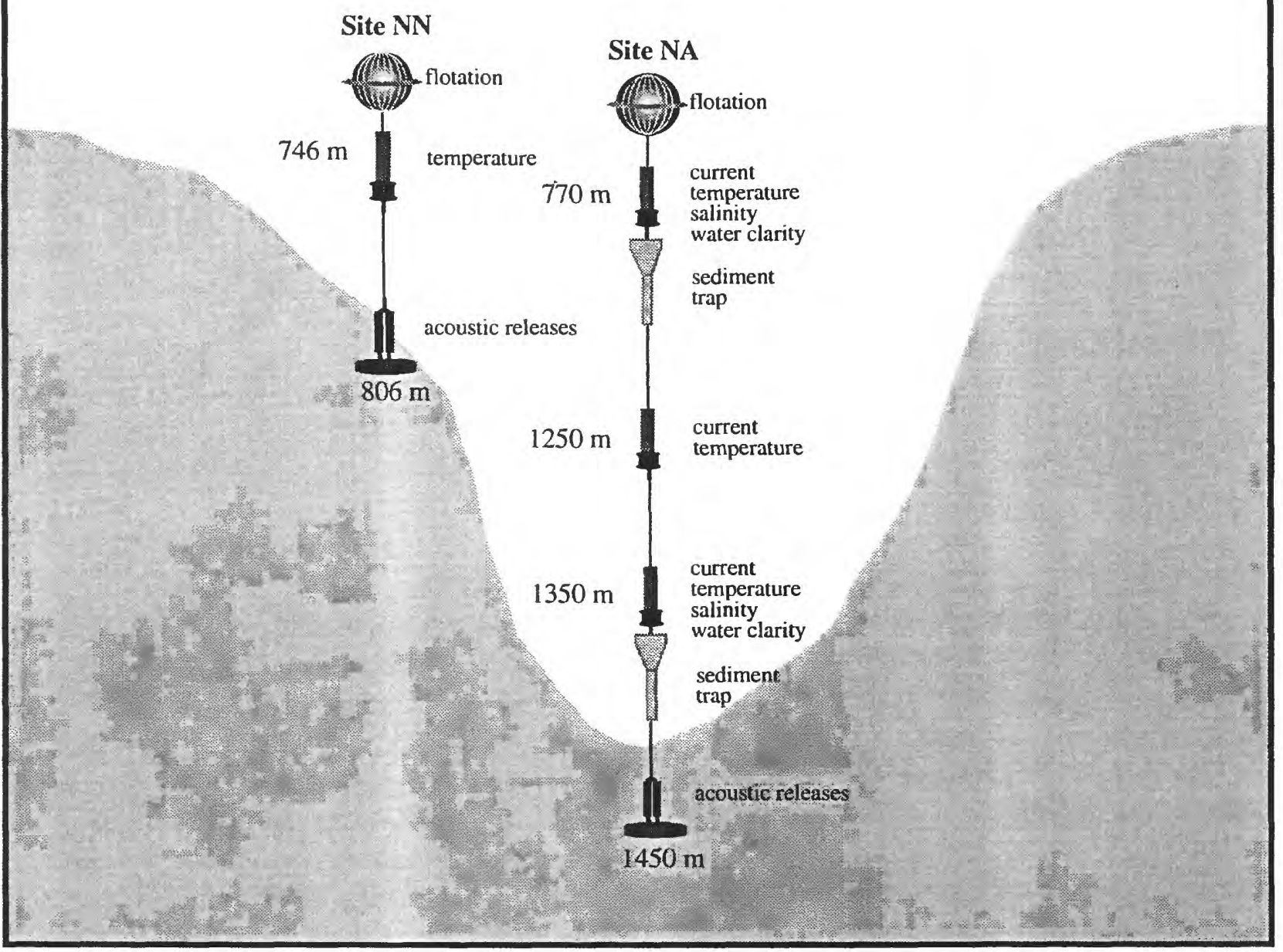

Figure 2b. Cross section view of mooring set-up at "narrow" section of Monterey Canyon.

collected suspended sediment in a trap at 4 of the sites. The moored array was designed to monitor conditions of the water so that reasonably stable estimates of the processes controlling circulation and sediment transport could be made.

Three of the moorings were located in a cross-canyon array, one on each slope and one in the axis, in a dynamically "wide" section of the canyon seaward of the intersection with Carmel Canyon in order to examine the 3-dimensional structure of the flow at depths just below the rim and deep within the canyon. In particular, it is hypothesized that a measurable current shear can develop across this wide portion of the canyon. The size of the shear may change with depth below the rim. One current meter was located in the middle of the canyon axis, but above the canyon rim in order to monitor flow over Monterey Canyon. This measurement will allow us to relate the circulation in the canyon to the parameters of the flow over the canyon.

Two other moorings were deployed closer to shore in a dynamically "narrow" section of the canyon. These moorings allow us to determine how spatial structures in flow patterns change between dynamically narrow and wide sections of the canyon. They also allow a determination of phase propagation of tidal currents along the canyon axis.

A sixth mooring was deployed farther down canyon on Monterey Fan. This mooring not only extends the moored array significantly, but the down canyon site allows us to monitor any significant turbidity currents that can reach Monterey Fan. 
Hence it extends our understanding of nutrient transport pathways to the abyss and the processes that deposit materials in Monterey Fan.

Each mooring in the array had between 1 and 3 instrument packages that measured current, temperature and optionally salinity, water clarity and suspended sediments (Figures 2 a,b,c). An attempt was made to locate instrument packages at common depths at each cross-section.

\section{Data sets and statistical methods}

This report is a statistical and pictorial description of the data collected. The data sets from each instrument package have been decoded, transcribed into scientific units and passed through several processing steps. The data were checked for quality and errors, caused by instrument noise or failures, using programs developed at Woods Hole Oceanographic Institute (Tarbell, et al, 1988). The data were then analyzed using standard time series and statistical procedures. These procedures included temporal plots, means, standard deviations, maximum values, minimum values and spectra of each data variable (Appendix A, B, D). In addition, correlation, coherence and frequency-response statistics provided information on the rela- tion of the various data sets. All times are in Greenwich mean time (GMT). The units for the currents are centimeters per second $(\mathrm{cm} / \mathrm{s})$, temperature degrees Celsius $\left({ }^{\circ} \mathrm{C}\right)$ and salinity parts per thousand (ppt).

The basic sample interval for all variables was 15 minutes (Table 1). All data in this report have been averaged into records that have an hour sample interval (denoted hour-averaged records). The data have also been lowpass filtered to remove oscillations with periods shorter than 33 hours. Since the majority of the variability at the shorter periods is due to tidal forcing, these lowpass-filtered records are referred to as subtidal records.

\section{Moored current observations}

Current observations were collected at all sites during the deployment period. At the "narrow" and "wide" sections of the canyon, current meters were located at common depths just below the lip of the canyon and near bottom (Figure 2a, $2 b)$. In order to ensure the insturments on the moorings would not be damaged or buried by a possibly large turbidity flow, the deepest instruments were located $100 \mathrm{~m}$ above the sea bed. It was thought that turbidity currents at the "fan" site

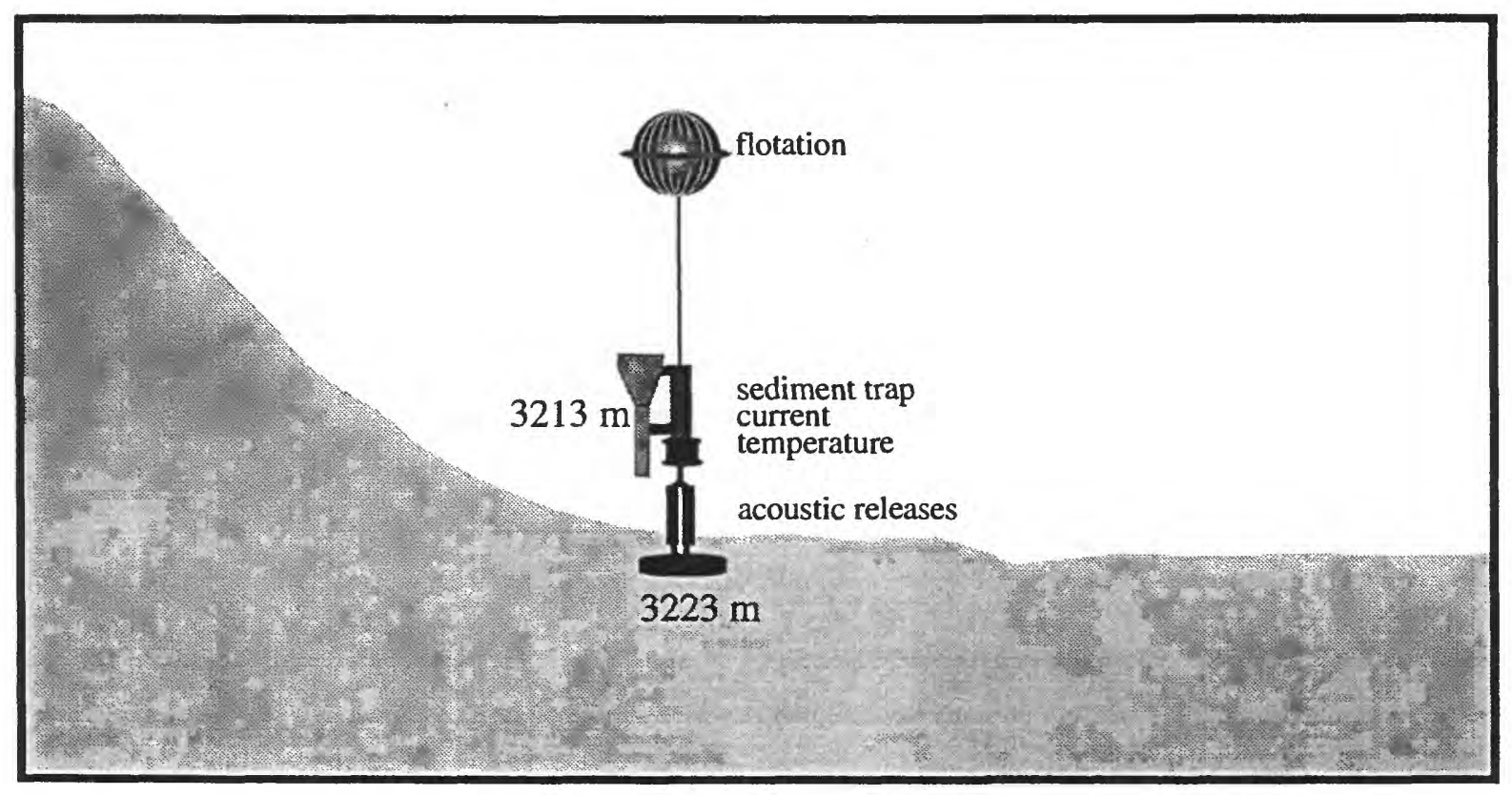

Figure 2c. Cross section view of mooring set-up on Monterey Fan. 


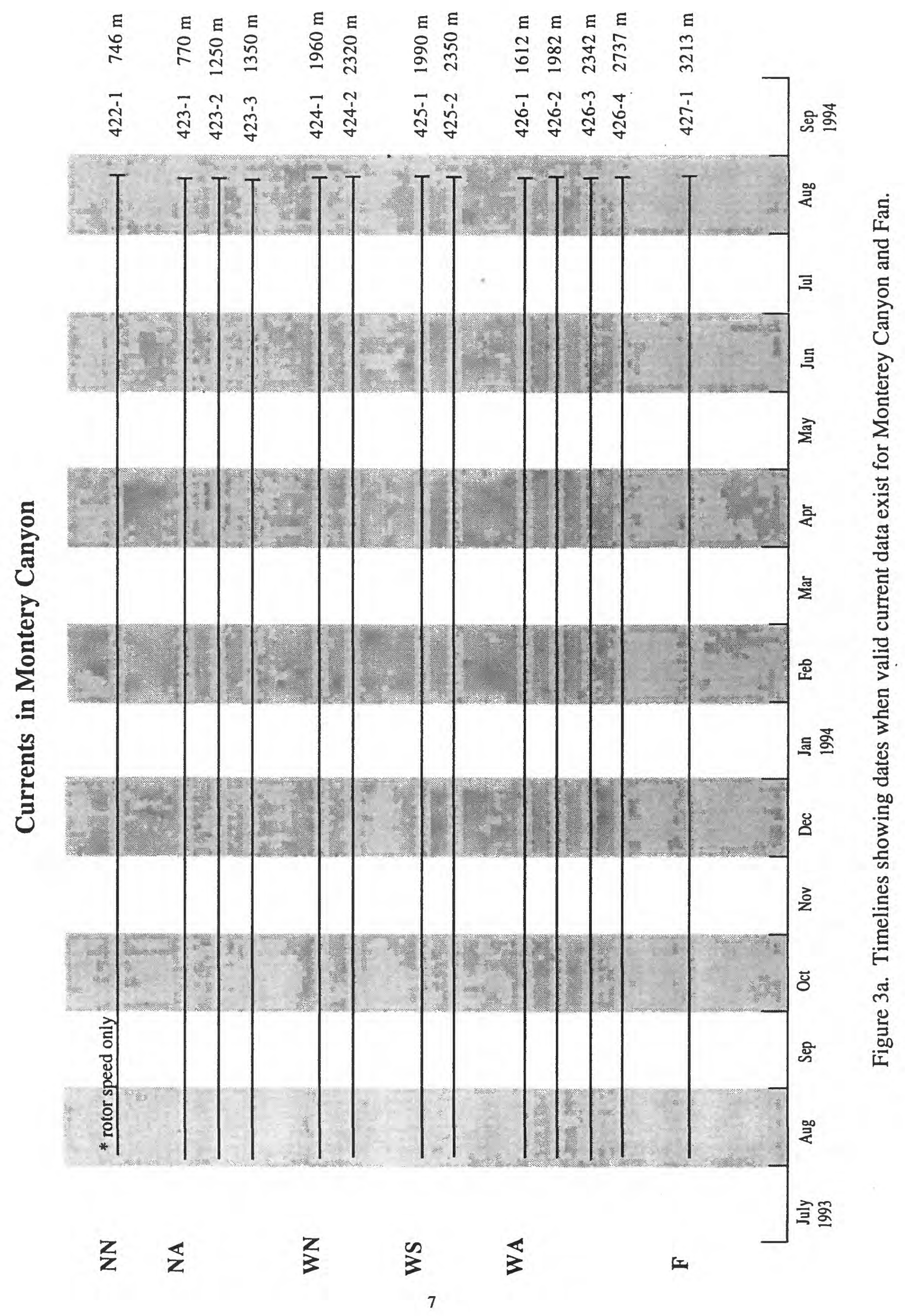




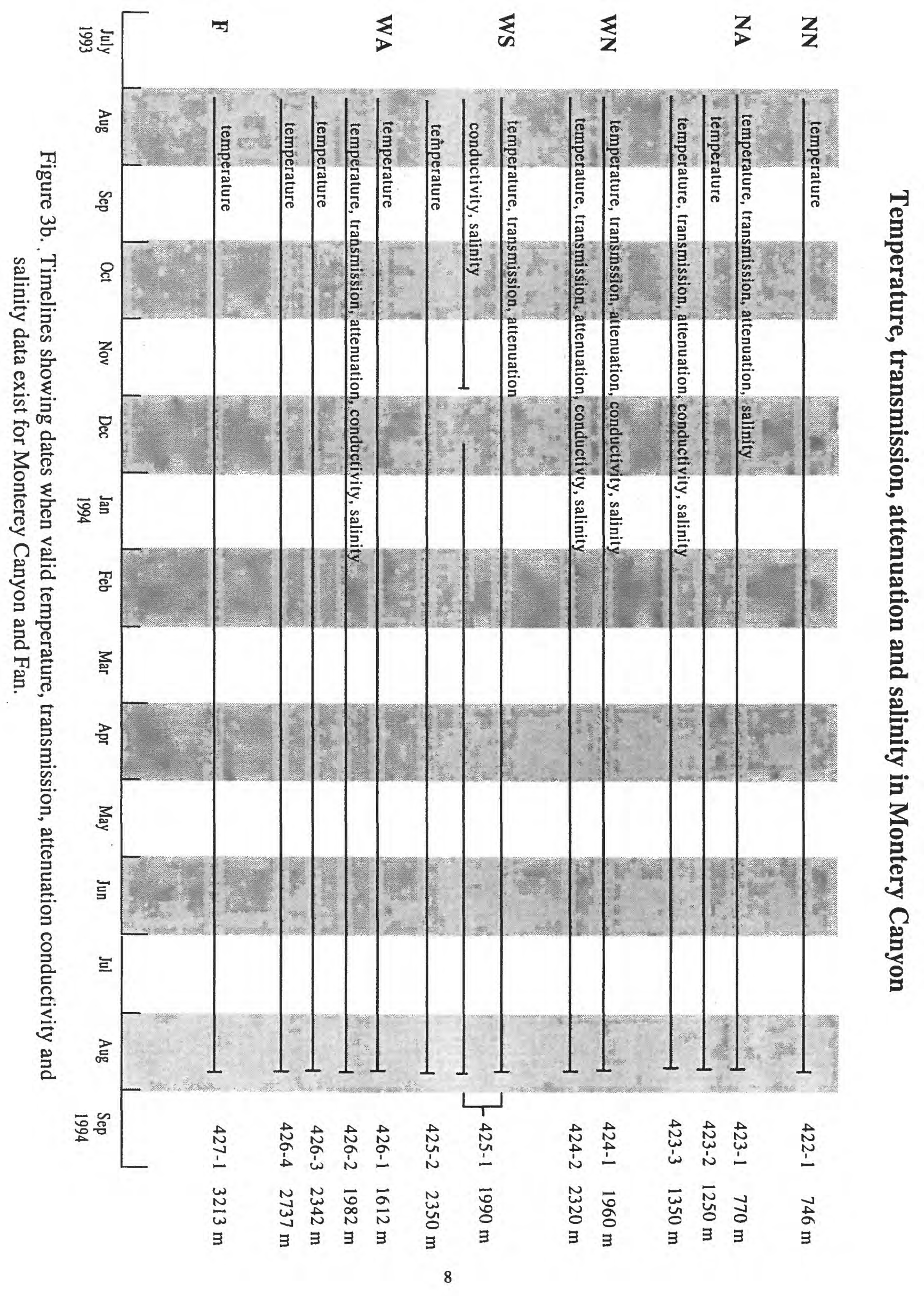


would not be as energetic as found in the upper reaches of the canyon. Hence the single current meter was located $10 \mathrm{~m}$ off the sea bed (Figure 2c).

The currents at all the moorings sites were rotated into a coordinate system that is aligned with, or perpendicular to, the alongshelf isobaths. At site NA the positive along canyon direction is $4^{0}$; positive cross canyon is $094^{\circ}$. At sites WA, WS and $\mathrm{WN}$ the positive along canyon direction is $85^{\circ}$; positive cross canyon is $175^{\circ}$. At site $\mathrm{F}$ the positive along canyon direction is 170 ; positive cross canyon is $107^{\circ}$. These orientations are chosen so that at all sites, positive along-canyon currents flow toward the head of the canyon. Positive, crosscanyon currents flow to the right of positive alongcanyon currents.

Several statistical quantities have been included in this data report. The mean, standard deviation, minimum and maximum of the hour-averaged current records are listed in the tables in Appendix A.

Error bars at the $95 \%$ confidence level have been calculated for the mean along and cross-canyon currents. The error bars around the mean value indicate how stable the calculated mean is. In order for a reliable mean direction to be estimated, the error bars can not span an interval that includes zero. Significant mean directions have been highlighted in the tables.

The formula for the error bar around the mean is

$$
\frac{\Phi t_{m: \alpha / 2}}{\sqrt{m+1}}
$$

where $t_{m ; \alpha / 2}$ is the student $\mathrm{t}$ statistic with $\mathrm{m}$ degrees of freedom at the $100(1-\alpha) \%$ confidence level. $\Phi$ is the standard deviation of the subtidal data set. The degrees of freedom of a record is the record length divided by the autocorrelation scale. The autocorrelation scale for along and cross-canyon currents was 4 days at most current sites, but lengthen to 17 days for cross-canyon currents above the wide portion of the canyon axis.

Tidal currents are the major current components in the canyon. It is to be expected that the narrowing of the canyon will cause barotropic tidal currents to be enhanced along the canyon axis. Baroclinic tidal currents can be generated along the canyon floor and propagate along the canyon axis. These strengthened tidal currents increase the potential for material to be eroded from the canyon walls or resuspended from the canyon floor. Hence, the characteristics of the major diurnal $\left(\mathrm{O}_{1}\right.$ and $\left.\mathrm{K}_{1}\right)$ and semidiurnal $\left(\mathrm{M}_{2}\right.$ and $\left.\mathrm{S}_{2}\right)$ tidal constituents are calculated for each measurement site (Tables A5 and A6). The tidal amplitudes are calculated for the existing record length of each data set (Table D1).

Several sections of this data report contain a series of figures that display characteristics of the measured currents. The time series of the houraveraged and subtidal along and cross-canyon currents are in Appendix B. The time axes are the same for all current sites so that comparisons can easily be made between the instruments. The houraveraged currents are shown first (Appendix B, pgs. B1-B11), the subtidal currents follow (pgs. B12B21). An additional plot type, vector plots of the subtidal currents, are shown in Appendix C. These figures display the direction and amplitude of the current vectors simultaneously.

The energy in the currents at each measurement site is depicted as a function of the frequency of the process in Appendix D. A variance-conserving autospectra is calculated for the along and cross-canyon currents. We chose a variance-conserving spectra in order to highlight those frequencies that had the largest energies; the dominant processes occupy the biggest areas on the plots. The tidal frequencies generally have a large fraction of the energy; these large spectral peaks are found at frequencies above $10^{-5}$ hertz (1.2 days).

All spectra for the moored array are calculated with similar Fourier transform parameters. Each record was divided into pieces 2112 hours long that overlapped each other by $50 \%$ (Table D1). Each piece was windowed with a Hanning window shape in order to reduce leakage of energy from the dominant frequencies into the less energetic frequency bands. The spectra for all pieces at one location were averaged together. 
Moored temperature, salinity, attenuation and transmission observations

Measurements of temperature were obtained at each sites in the moored array (Table 1, Figure $3 b$ ). Salinity and attenuation were monitored for at least one depth at 4 of the sites in the array and water clarity was monitored at 3 of the sites.

The mean, standard deviation, minimum and maximum values for both the hour-averaged and subtidal data are listed in Tables A3 and A4. Plots of all the data are located in Appendix F. Both the hour-averaged and subtidal data are depicted for temperature and salinity.

The attenuation data has been edited for obvious spikes and other bad data. Attenuation is an optical measurement. Hence, the instrument that make the measurement are subject to fouling from growth of organisms on the lenses. The fouling happens over periods of weeks. Surface instruments foul faster because more light is available. This fouling has not been removed from the attenuation records. Hence, the gradual decrease in water clarity that may be observed during the deployment periods is artificial and should be discounted.
Records from the mooring deployed at NA show that an unusually strong turbidity event occurred $100 \mathrm{~m}$ above the bed (mab) from February 8 through February 15, 1994 (Figure 4). Suspended material dense enough to initially block the transmissometer passed the site; the water column slowly cleared over the next week. At the beginning of the event, temperature increased by 1 degree, the pressure sensor failed and currents flowed down canyon. Unfortunately, no measurements were collected below 100 mab. It is probable that the main structure of the turbidity event passed below our deepest sensors.

\section{Sediment traps}

Extremely large particulate sediment fluxes of $22-60 \mathrm{~g} / \mathrm{m}^{2} /$ day (Figure 5) were recorded at the $1360 \mathrm{~m}$ sediment trap at NA prior to it overflowing in November, 1993, although no major signal indicating a large resuspension event was recorded by the transmissometer that was located 10 meters above the trap. These sediment mass fluxes were approximately an order of magnitude greater than those measured at a trap located at $780 \mathrm{~m}$ on the same mooring. The shallower trap fluxes ranged from $2-4 \mathrm{~g} / \mathrm{m}^{2} /$ day (Figure 5). The intervalometer

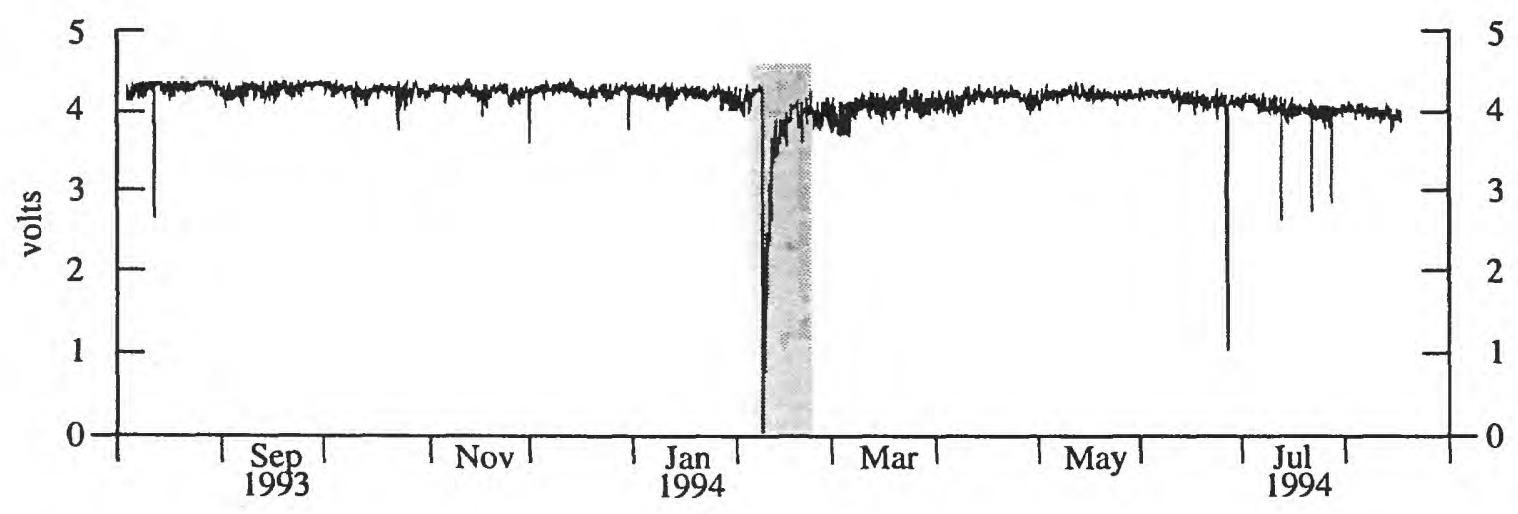

Figure 4. Hour-averaged transmission record from $1360 \mathrm{~m}$ at site NA. The gray box shows an unusually strong turbidity event that occurred from February 8 through February 15, 1994. 


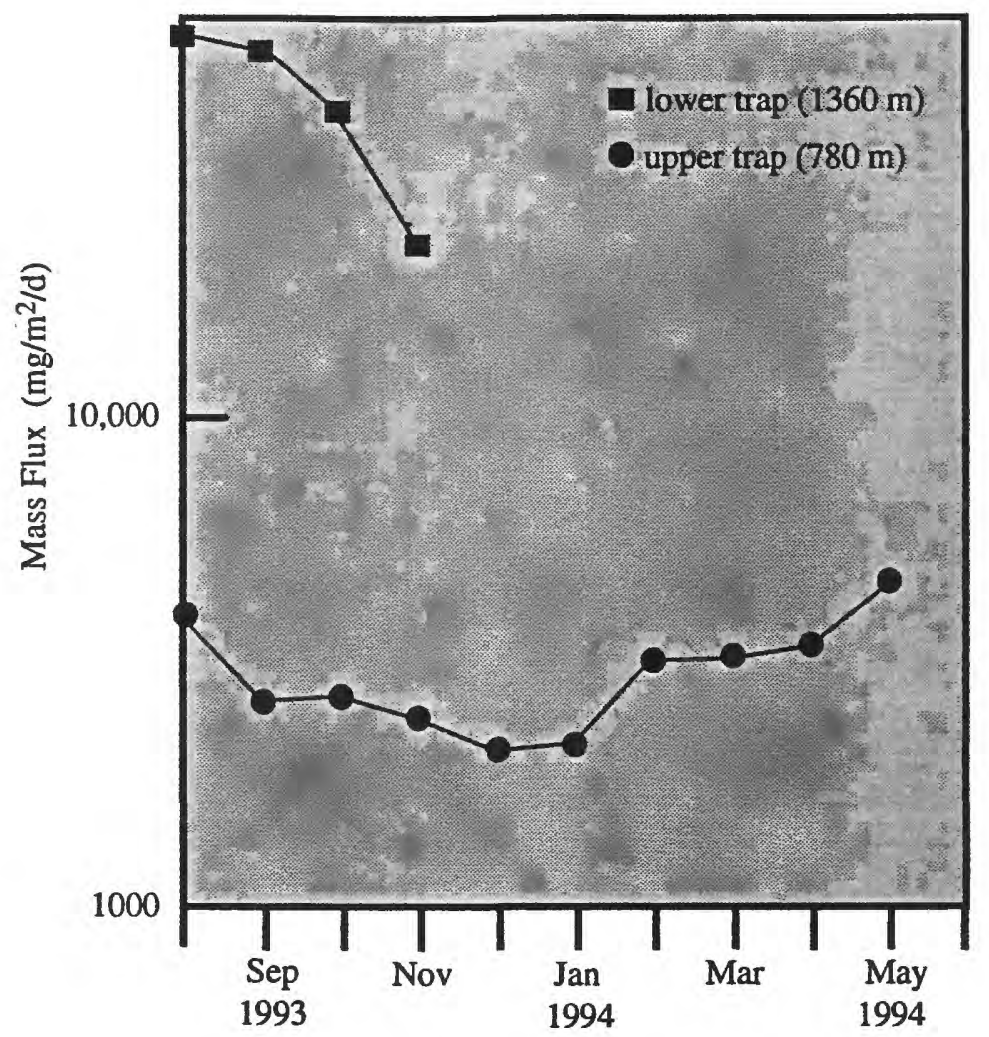

Figure 5. Sediment trap mass flux at site NA.

battery pack on the upper trap apparently failed after 10 events (months) as no more events after 10 were preserved and there was some wash-out of the final events from the tube as no particulate flux events were recovered after the tenth event (May 28, 1994).

Much of the material in the $1360 \mathrm{~m}$ trap was black and emitted an obvious hydrogen sulfide smell when first examined. The black sediment was overlain by more gray/green material collected just prior to the overflow of the trap in November. It is possible that the black sediment was originally part of an organic-rich, fine-grained sediment blanket that tends to drape extensive regions of the steep axis walls in upper Monterey Canyon. It was carried to the trap by the failure and subsequent down canyon movement of this material.

Dramatic differences in the mass fluxes are a function of trap location relative to canyon depth and proximity to canyon walls, the deeper trap experienced much larger fluxes due to particulate remobilization/slumping events (down slope/down canyon wall movement). It is unknown how often these transport events occur, whether they are predominantely triggered by major storm events, by the enhanced tidal currents typically found in canyons, by internal waves, by the frequent seismic activity in the Monterey Canyon region or by other processes. The relative instability of thick, muddy sediment accumulated along the steep-sided canyon walls and the recent history of sediment movement suggest that episodic, if not frequent, turbid sediment pulses move down Monterey Canyon.

\section{Wind and sea level observations}

For the same time period of this study, records of wind velocity and atmospheric pressure and sea level heights were obtained from the National Data Buoy Office and the National Ocean Service (Table 2, Figure 6). Winds along the coast were measured by offshore meteorological buoys 


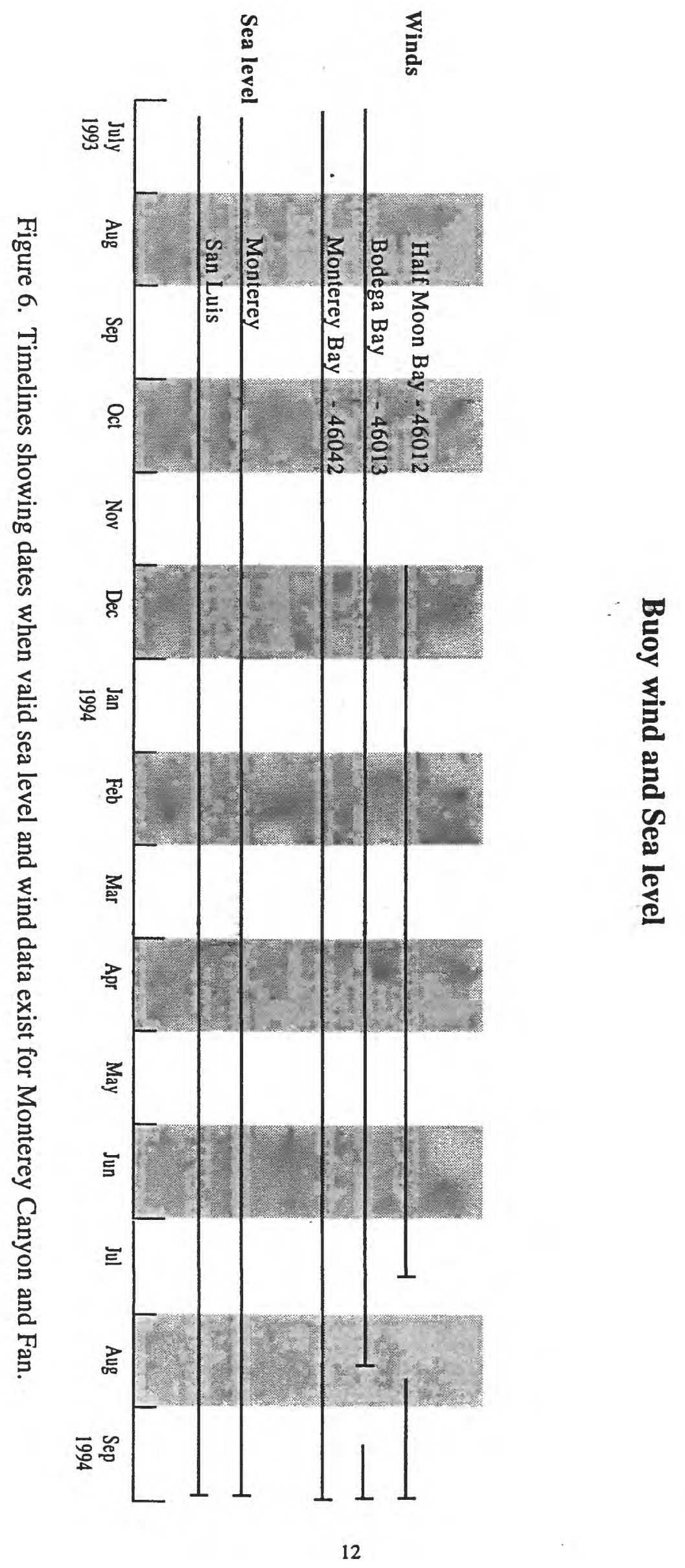


at 3 locations between Bodega Bay and Monterey, California (Figure 7). The 2 sea level stations were located on the coast at Monterey Harbor and Port San Luis (Figure 7).

The hourly observations of wind velocity were converted into estimates of wind stress because wind stress represents the actual force that causes water to move over the shelf and slope. Wind stress was calculated from the formula by Wu (1980).

$$
\tau=\rho c_{D} \mathbf{W}|\mathbf{W}|
$$

where $\rho$ is the air density $\left(0.0012 \mathrm{~g} \mathrm{~cm}^{-3}\right), c_{D}$ the drag coefficient and $\mathbf{w}$ the wind velocity. The drag coefficient increases with wind strength

$$
c_{D}=\left(0.8+0.065\left|W_{10}\right|\right) \times 10^{-3}
$$

where $W_{10}$ is the wind speed $10 \mathrm{~m}$ above the surface in meters per second. The wind stress was lowpass filtered and rotated into an alongshelf/ cross-shelf coordinate system. The positive alongshelf wind stress direction is $330^{\circ}$ for the bouys off Monterey and Half Moon Bay (Buoys 46012 and 46042$), 320^{\circ}$ for the northern most buoy (46013). These orientations are roughly parallel to the local alongshelf topography. The positive crossshelf directions are $60^{\circ}$ and $50^{\circ}$, respectively.

The coastal sea level records were converted into records of synthetic subsurface pressure (SSP) by adding atmospheric pressure to the sea level records. SSP is a better representation of the pressure forces that cause currents to move along the coast because changes in sea level caused by high and low pressure systems are removed from the record. The mean was removed from each SSP record. The record was lowpass filtered to remove the tidal signal.

The wind stress and sea level information is presented in appendix G. The tidal amplitudes computed from the unfiltered SSP records are given in Table G2. The basic statistics for the subtidal wind stress records are given in Table G3. The subsequent section displays the temporal and spectral plots of winds stress and SSP data.

\section{Other data collected}

A mooring supporting 2 current meters was deployed at site F in August, 1994. and recovered in May, 1995. The data set from this mooring is

\begin{tabular}{|c|c|c|c|c|c|c|c|}
\hline \multirow[b]{2}{*}{ Data Type/Station } & \multirow{2}{*}{$\begin{array}{l}\text { Water } \\
\text { Depth } \\
\text { (m) }\end{array}$} & \multirow{2}{*}{$\begin{array}{c}\text { Start } \\
\text { Time } \\
\text { (M/D/Y) } \\
\end{array}$} & \multirow{2}{*}{$\begin{array}{c}\text { Stop } \\
\text { Time } \\
\text { (M/D/Y) }\end{array}$} & \multicolumn{2}{|c|}{ Position } & \multirow[b]{2}{*}{ Data Type } & \multirow{2}{*}{$\begin{array}{c}\text { Sample } \\
\text { Interval } \\
\text { (minutes) }\end{array}$} \\
\hline & & & & Latitude & Longitude & & \\
\hline $\begin{array}{l}\text { Sea level } \\
\text { Monterey } \\
\text { Port San Luis }\end{array}$ & $\begin{array}{l}\text { n/a } \\
\text { n/a }\end{array}$ & $\begin{array}{l}08 / 01 / 93 \\
08 / 01 / 93\end{array}$ & $\begin{array}{l}09 / 01 / 94 \\
09 / 01 / 94\end{array}$ & $\begin{array}{l}3636.00 \mathrm{~N} \\
3510.20\end{array}$ & $\begin{array}{l}12153.30 \\
12045.10\end{array}$ & $\begin{array}{l}\text { SL } \\
\text { SL }\end{array}$ & $\begin{array}{l}60 \\
60\end{array}$ \\
\hline 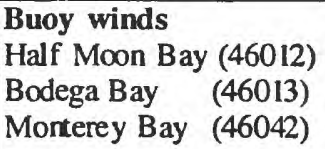 & $\begin{array}{r}89 \\
125 \\
89\end{array}$ & $\begin{array}{l}12 / 01 / 93 \\
08 / 01 / 93 \\
08 / 01 / 93\end{array}$ & $\begin{array}{l}09 / 01 / 94 \\
09 / 01 / 94 \\
09 / 01 / 94\end{array}$ & $\begin{array}{ll}37 & 23.12 \mathrm{~N} \\
38 & 13.39 \mathrm{~N} \\
36 & 45.01\end{array}$ & $\begin{array}{l}12243.17 \mathrm{~W} \\
12317.56 \mathrm{~W} \\
12224.227\end{array}$ & $\begin{array}{l}\text { ST,P,AT,W } \\
\text { ST,P,AT,W } \\
\text { ST,P,AT,W }\end{array}$ & $\begin{array}{l}60 \\
60 \\
60\end{array}$ \\
\hline
\end{tabular}
depicted in Appendix G.

Table 2. Sea level, surface wind and buoy wind data available.

\footnotetext{
$\mathrm{ST}=$ sea temperature

$\mathrm{P}=$ atmospheric pressure

$\mathrm{AT}=$ air temperature

$\mathrm{SL}=$ sea level

$\mathrm{W}=$ wind (speed and direction)
} 


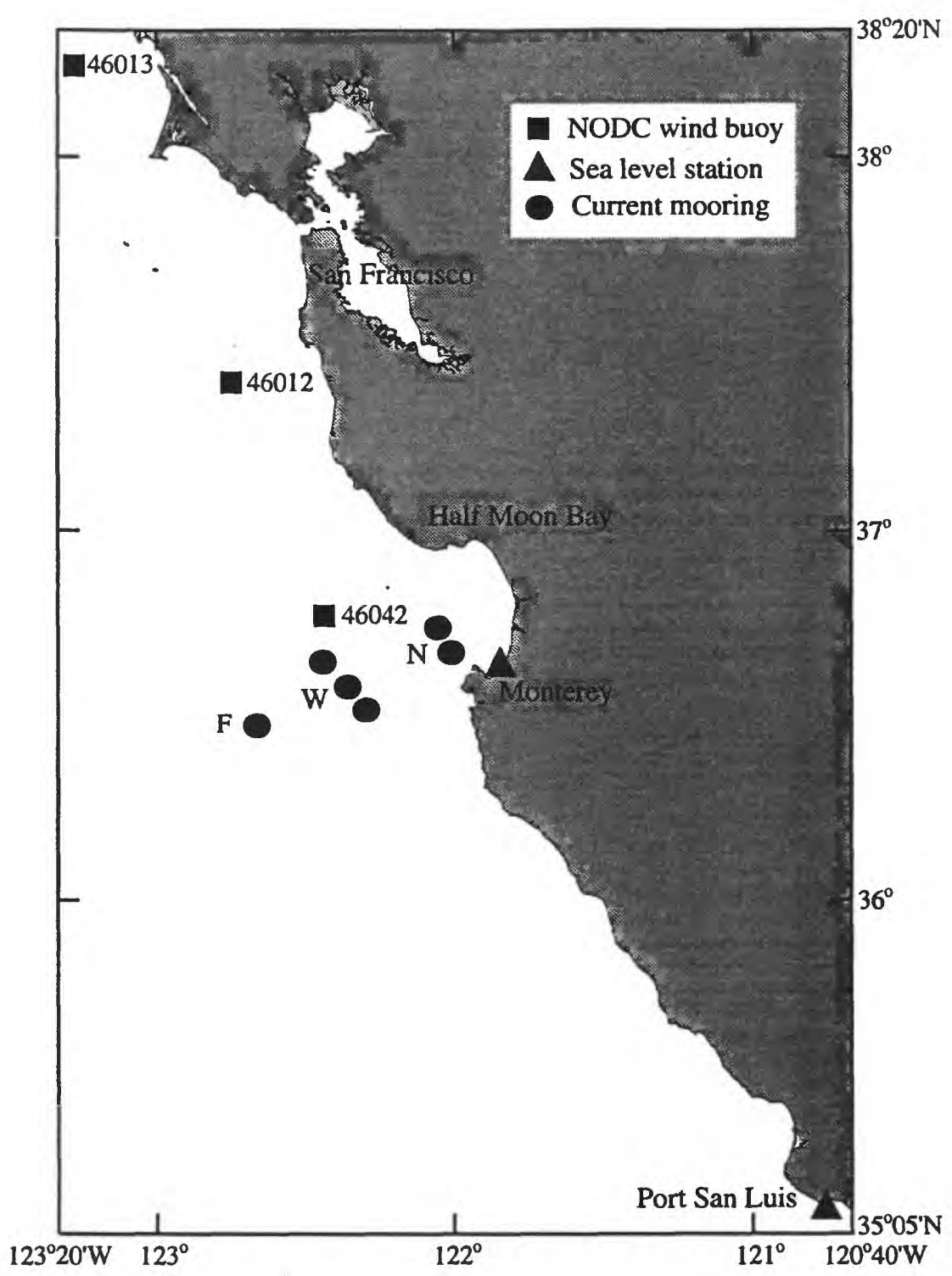

Figure 7. Location of wind buoys and sea level stations.

\section{ACKNOWLEDGMENTS}

We would like to thank William Strahle, Marinna Martini, Richard Rendigs, Gerry Hatcher and Todd Anderson for preparing, deploying and recovering the many types of instruments used in this project. Francis Hotchkiss decoded and cleaned up the raw data sets. The crew of the research vessels Robert Gordon Sproul, David Starr Jordan and McArthur ably assisted in the deployments and recoveries of instruments during the program. We would also like to thank Norman Maher for the 3D image of Monterey Canyon. This research was jointly sponsored by the U.S. Geological Survey and the Office of Naval Research under contract numbers N00014-93-1-0403 and N00014-93-F-0039. 


\section{REFERENCES}

Beardsley R. C. and S. J. Lentz, 1987. The Coastal Ocean Dynamics Experiment collection: An introduction. Journal of Geophysical Research, 92, p. 1455-1463.

Garfield, N. T. A. Rago, K. J. Schnebelle anid C. A. Collins, 1994. Evidence of a turbidity current in Monterey Submarine Canyon associated with the 1989 Loma Prieta earthquake. Continental Shelf Research, 14, No. 6, p. 673-686.

Hughes, R. L., K. N. Ofosu, and B. Hickey, 1990. On the behavior of boundary undercurrents near canyons. Journal of Geophysical Research, 95 , p. 20,259-20,266.

Itsweire, E. C. and T. R. Osborn, 1988. Microstructure and vertical velocity shear distribution in Monterey Bay. Small-scale turbulence and mixing in the ocean. J. C. J.Nihoul and B. J. Jamart, eds., Elsevier, p. 213-228.

Klinck, J. M., 1989. Geostrophic adjustment over submarine canyons. Journal of Geophysical Research, 94, p. 6133-6144.

Koehler, K. A., 1990, Observations and modeling of currents with the Monterey Bay during May 1988. Masters Thesis, Naval Postgraduate School, Monterey, California.

Lueck, R. G. and T. R. Osborn, 1985. Turbulence measurements in a submarine canyon. Continental Shelf Research 4, p. 681698.

Moody, J. A., B. Butman and M. H. Bothner, 1987. Near-bottom suspended matter concentration on the Continental Shelf during storms: estimates based on in-situ observations of light transmission and particle size dependent transmissometer calibration. Continental Shelf Research, 7, p. 609628.

McCullough, J., 1975. Vector-averaging current meter speed calibration and recording technique. Technical Memorandum 75-44, Woods Hole Oceanographic Institute, Masschusetts, $35 \mathrm{p}$.
Mero, T. M., 1982. Performance tests for the EG\&G vector-measuring current meter (VMCM), in Proceedings of IEEE Second Working Conference on Current Measurements, edited by M. Dursi and W. Woodward, Institute of Electrical and Electronics Engineers, New York, p. 159-164.

Shepard, F.P., N. F. Marshall, P. A. McLoughlin, G. G. Sullivan, 1979. Currents in Submarine Canyons and Other Seavalleys, AAPG Studies in Geology No. 8, Amer. Assoc. Petrol. Geol., Tulsa, 173 p.

Tarbell, S. A., A. Spencer and E. T. Montgomery, 1988. The Buoy Group Data Processing System. Technical Memorandum 3-88, Woods Hole Oceanographic Institute, Masschusetts, $182 \mathrm{p}$.

Wu, J., 1980. Wind-stress coeffcients over the sea surface near neutral conditions. Journal of Physical Oceanography, 10, p. 727740. 


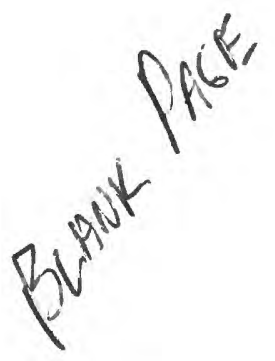




\section{Appendix A - Tables}

Table A1. - Hour-averaged horizontal current components $\quad$........................ A1

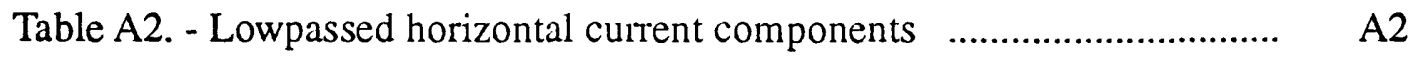

Table A3. - Hour-averaged temperature and salinity $\quad$................................ A3

Table A4. - Lowpassed temperature and salinity $\quad$.................................. A4

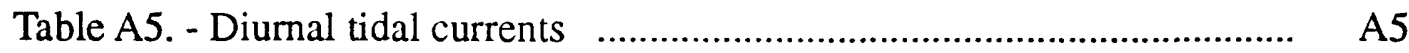

Table A6. - Semi-diurnal tidal currents $\quad$..................................................... A6 


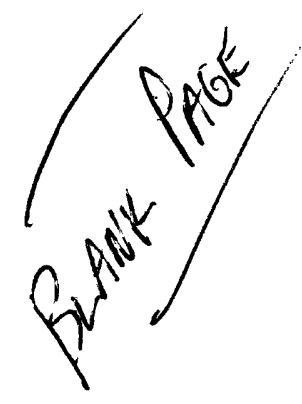




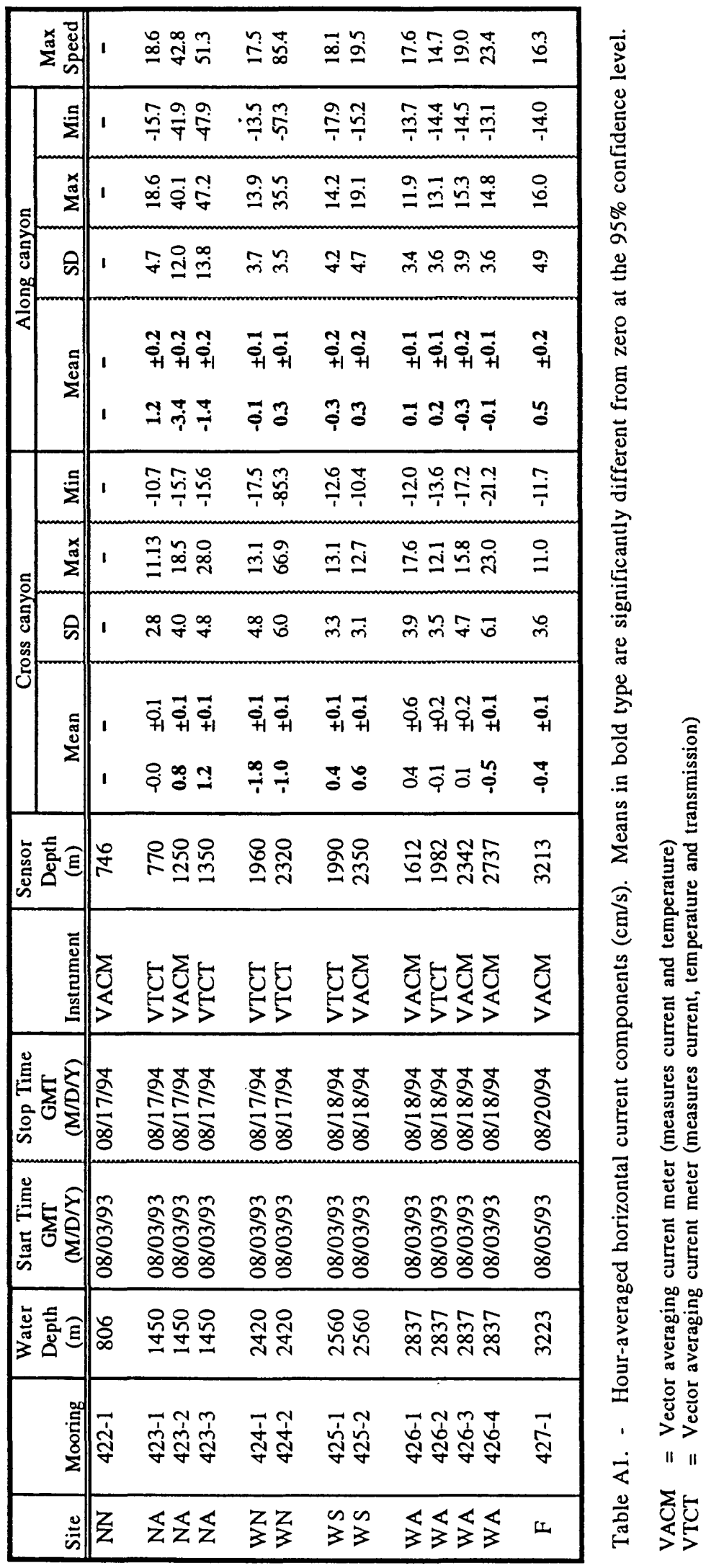




\begin{tabular}{|c|c|c|c|c|c|c|}
\hline$\sum$ & $\mid 1$ & 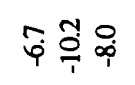 & 守苔 & $\tilde{\dot{p}}$ & テ゚ำ & $\stackrel{\infty}{i}$ \\
\hline \multirow{4}{*}{ | } & $\mid 1$ & ఈ సิ & $\bar{\gamma} \bar{N}$ & $n$ & ทีซั่ & $\infty$ \\
\hline & $\mid 1$ & 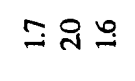 & $9 \beth$ & بْ & 士สัธ์ & 2 \\
\hline & 1 & 芦菅菅 & 可司 & 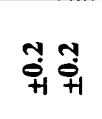 & 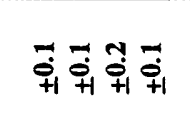 & ڤี \\
\hline & $\mid 1$ & $\exists$ 품 & $\overline{9} 8$ & 3 & 뭉요웅 웅 & 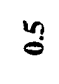 \\
\hline \multirow{5}{*}{ 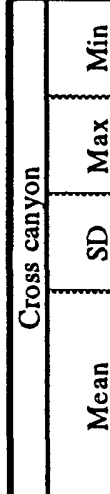 } & $\mid$ & 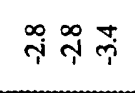 & $\stackrel{0}{i} \underset{7}{7}$ & สุ & 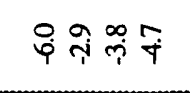 & $\stackrel{\infty}{;}$ \\
\hline & 1 & 눙요 & $\bar{\lambda}$ & $\tilde{m}$ & ๓ำ लㄷำ & $\pi$ \\
\hline & $\mid$ & 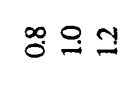 & $\cong$ & 85 & ำ $\beth \simeq$ & $\stackrel{\infty}{\circ}$ \\
\hline & \multirow{2}{*}{$\stackrel{\mid}{\Sigma} \stackrel{\mid}{\Sigma}$} & 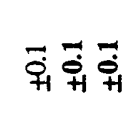 & $\overline{0} \overline{\dot{\theta}}$ & $\overrightarrow{0} \overrightarrow{0}$ & 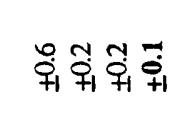 & $\bar{\Delta}$ \\
\hline & & & $\stackrel{\infty}{\rightarrow}$ & 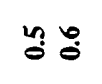 & 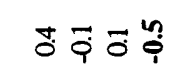 & : \\
\hline & $\frac{1}{2}$ & 尺ㅗㅁㅇㅠ & 윰 & 奇 & 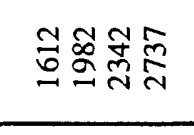 & $\stackrel{m}{\pi}$ \\
\hline & $\mid$ & 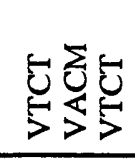 & $\begin{array}{l}E 5 \\
55\end{array}$ & 它焉 & 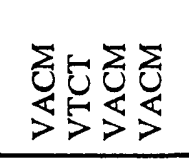 & $\sum_{\substack{\vdots \\
>}}$ \\
\hline 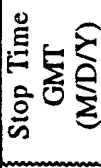 & 志 & 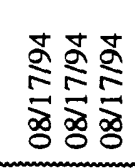 & 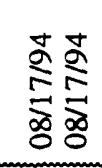 & 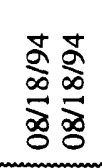 & 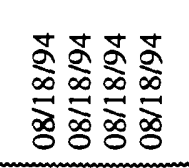 & 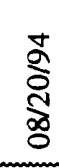 \\
\hline 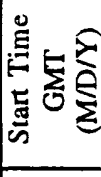 & 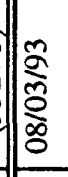 & 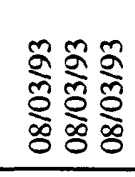 & 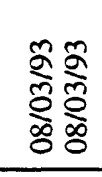 & 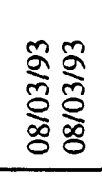 & 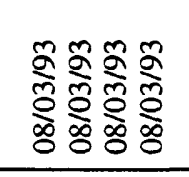 & 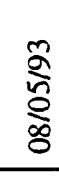 \\
\hline 离 & 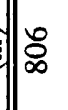 & 号号号 & 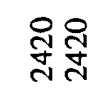 & 迤号 & 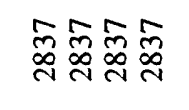 & స్లే \\
\hline & בิ่ & 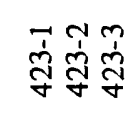 & $\frac{d}{4}$ & ซิ่ & 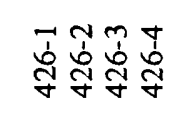 & $\overrightarrow{\vec{I}}$ \\
\hline $\bar{c}$ & z & 芯芯 & $z z$ & $\begin{array}{l}n \infty \\
3 \geqslant 3\end{array}$ & 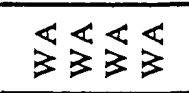 & $\omega$ \\
\hline
\end{tabular}




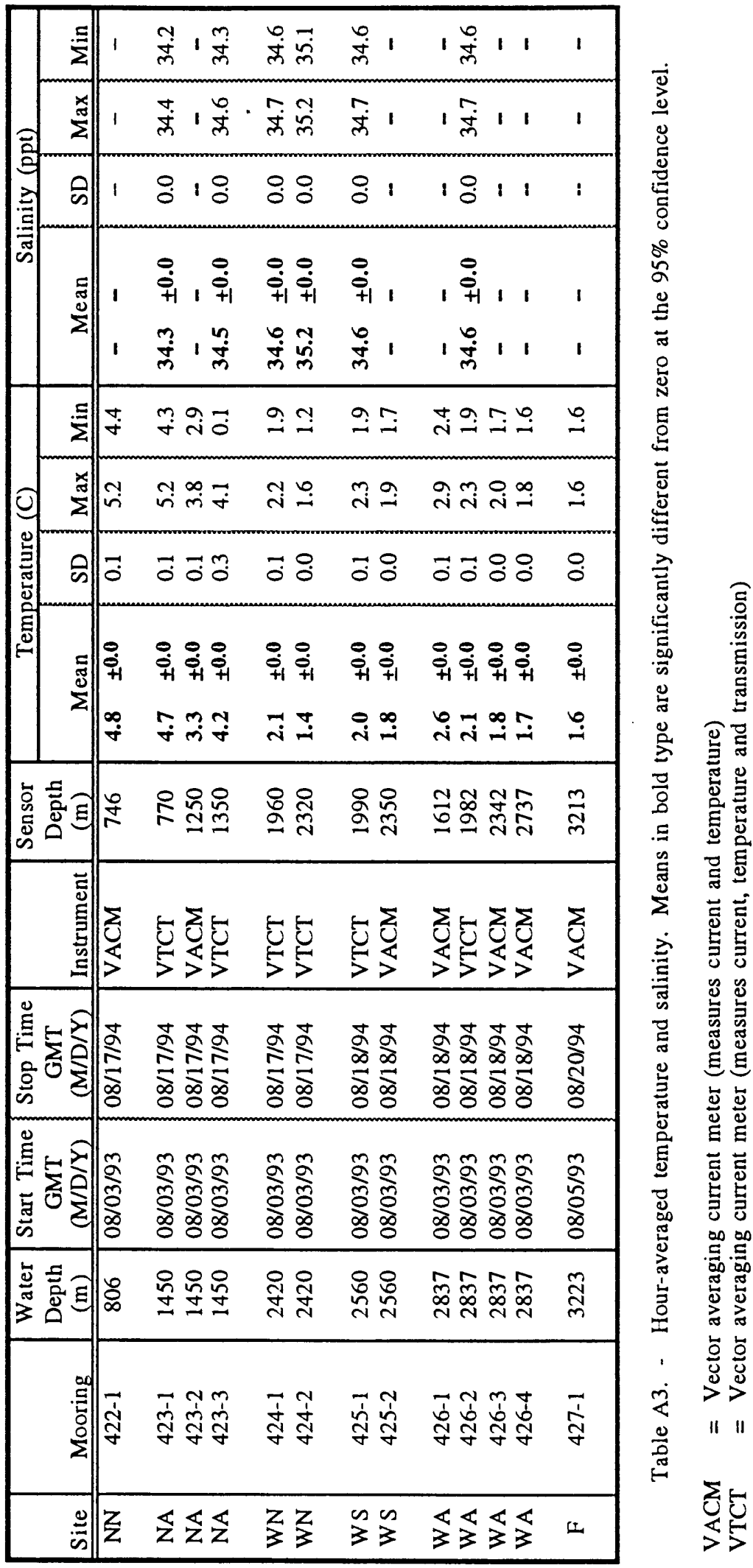




\begin{tabular}{|c|c|c|c|c|c|c|}
\hline$\dot{\Sigma}$ & $\sum \|^{2} 1$ & $\stackrel{n}{\stackrel{m}{m}} \stackrel{m}{m}$ & 它藏 & 官' & 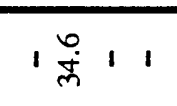 & 1 \\
\hline \multirow{4}{*}{ 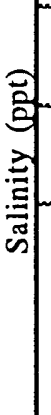 } & 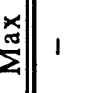 & 芦1先 & 美藏 & 吕 1 & 1 窇 1 & ' \\
\hline & की 1 & 81 & $\because:$ & 1 & 1811 & ' \\
\hline & 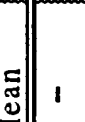 & 通, & $\stackrel{0}{\dot{0}}$ & $\stackrel{0}{\dot{i}}:$ & , & i \\
\hline & $\Sigma \|$ & 莤 i & 总芦 & $\begin{array}{ll}0 \\
\dot{m} & 1\end{array}$ & | & ' \\
\hline & $\sum \underset{i}{i}$ & $\because \overrightarrow{+} \vec{i}$ & 9 & $2=$ & 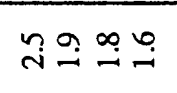 & $\stackrel{\circ}{\longrightarrow}$ \\
\hline$\sum_{\Sigma}^{\infty}$ & 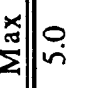 & ํำm & กี & 고 & 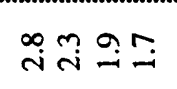 & $\stackrel{6}{-}$ \\
\hline की & $\hat{e} \| \overrightarrow{0}$ & $\overrightarrow{0} \tilde{0} \overline{0}$ & $\overrightarrow{0}: 0$ & $0: 0$ & 궁ㅇㅇㅇㅇㅇㅇ & $\stackrel{0}{0}$ \\
\hline \multirow{2}{*}{; } & : & 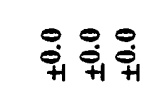 & $\stackrel{0}{\dot{i+1}}$ & $\stackrel{\circ}{\circ}$ & 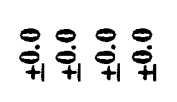 & $\stackrel{\circ}{0}$ \\
\hline & 究 & $F \dot{8}$ & $\vec{i} \stackrel{\square}{\dot{S}}$ & $\vec{i} \stackrel{\infty}{i}$ & $\stackrel{\text { i }}{\mathbf{i}} \tilde{i} \stackrel{\infty}{-}$ & $\stackrel{b}{-}$ \\
\hline 总总司司 & 甸 㩆 & 옹요 & \&ু్లి & 总瓷 & పే & $\stackrel{m}{\pi}$ \\
\hline & 部䇃 & 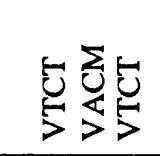 & $\begin{array}{l}50 \\
55 \\
5\end{array}$ & 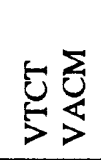 & 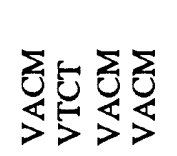 & $\sum_{U}^{\Sigma}$ \\
\hline 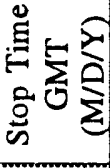 & है & 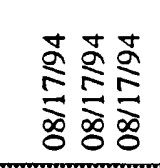 & 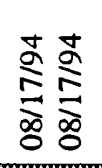 & 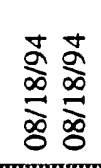 & 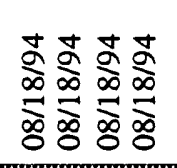 & 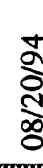 \\
\hline 总 & 象 & 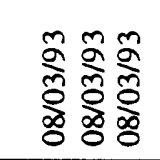 & 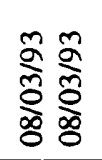 & 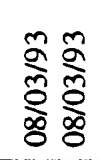 & 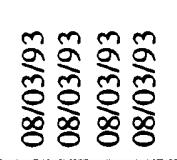 & $\tilde{\Omega}$ \\
\hline 总 & 勿 & 号景㝵 & 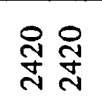 & 总总 & 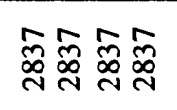 & స్ల \\
\hline & 赵| & 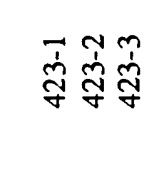 & 竎竎 & 宂守 & 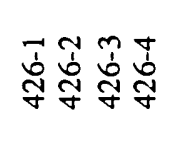 & $\frac{\bar{J}}{\mathscr{G}}$ \\
\hline & $=z$ & 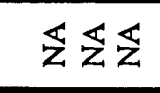 & $z_{z} z$ & $\begin{array}{l}n \infty \\
3\end{array}$ & 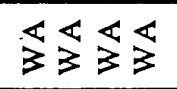 & \\
\hline
\end{tabular}




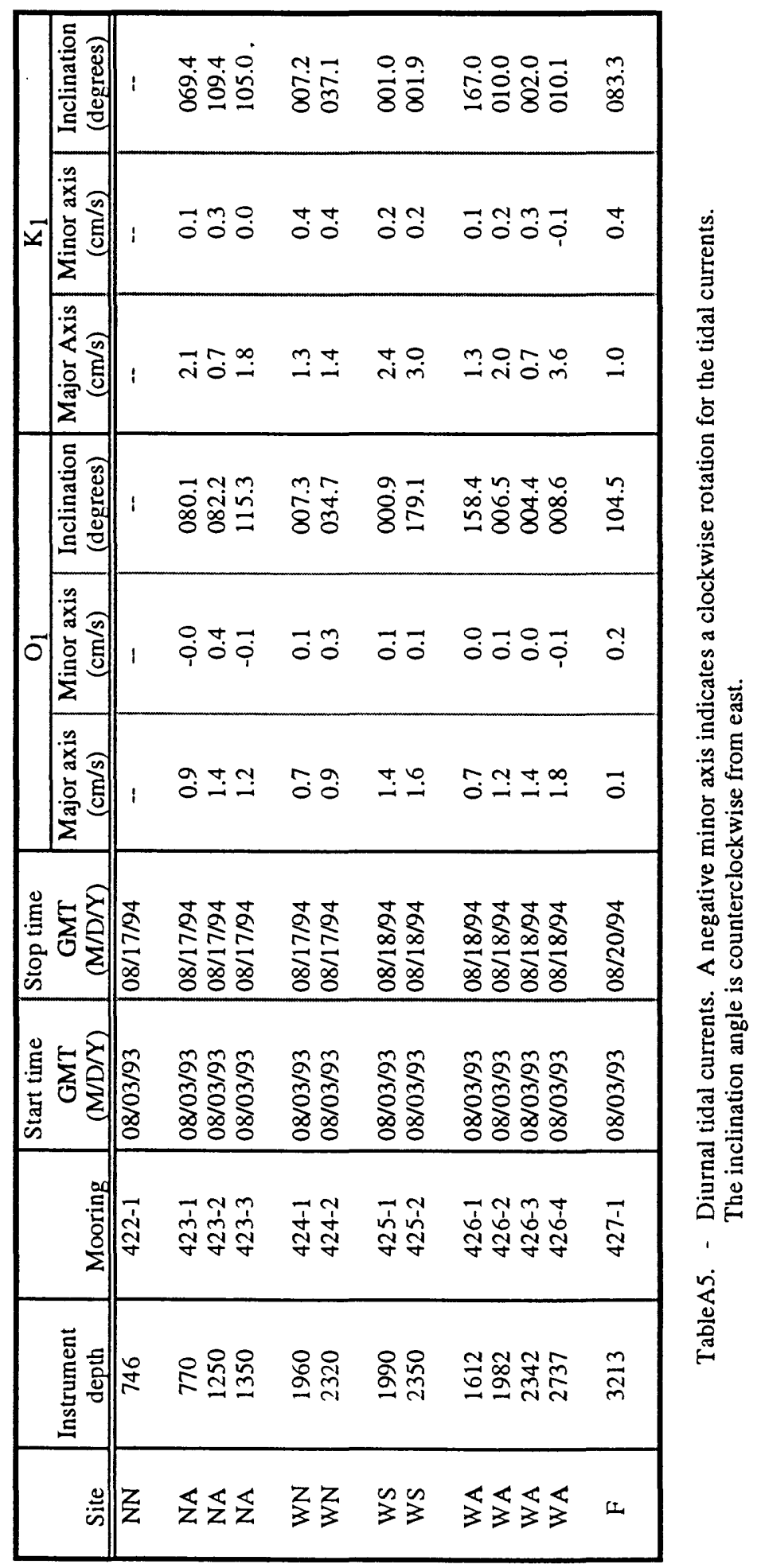




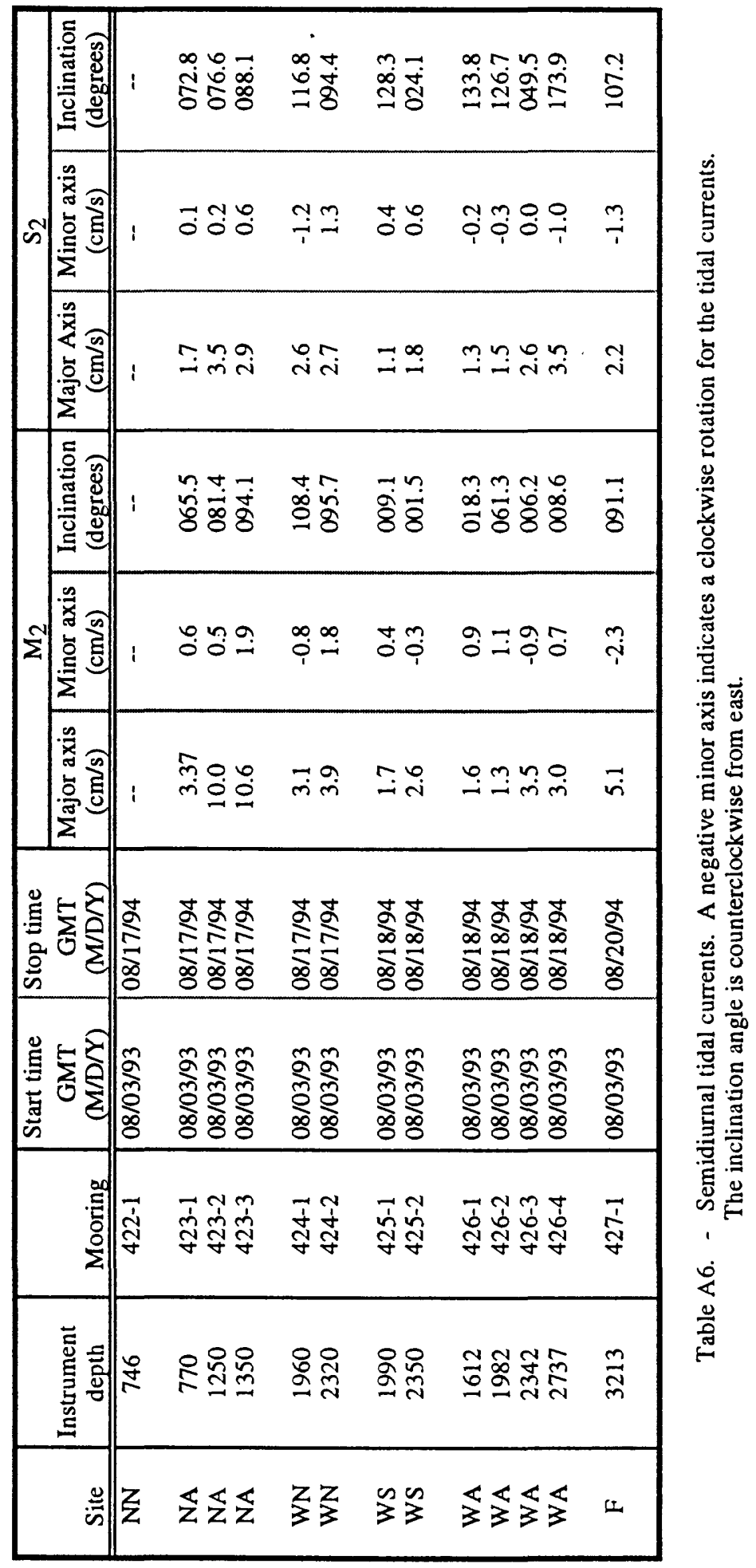




\section{Appendix B - Time series plots}

Plots of hour-averaged currents

B1 - B11

Plots of subtidal currents

$\mathrm{B} 12$ - B21 


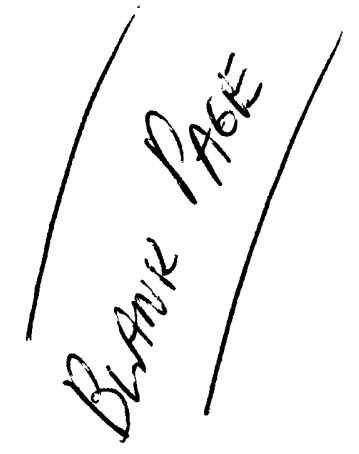



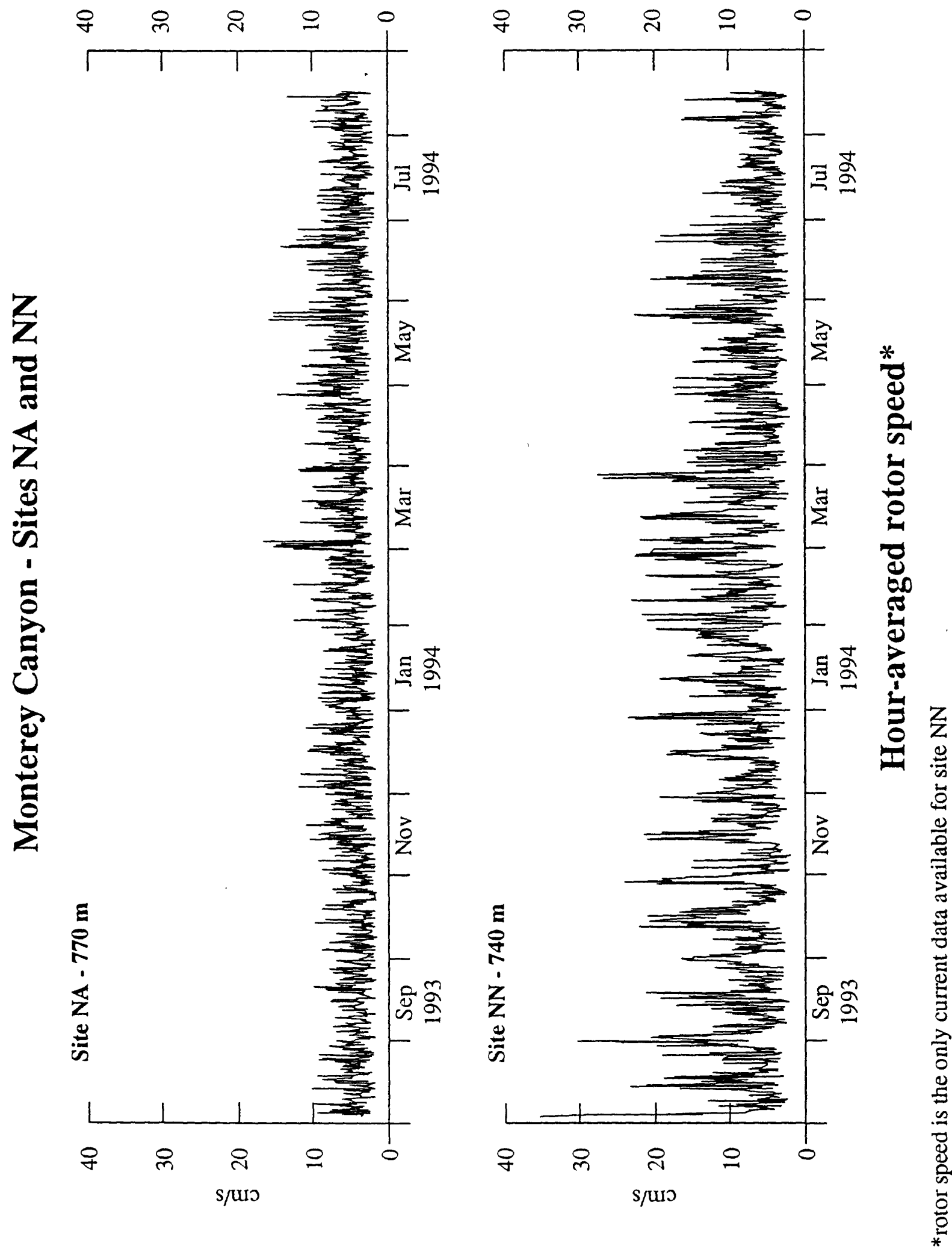

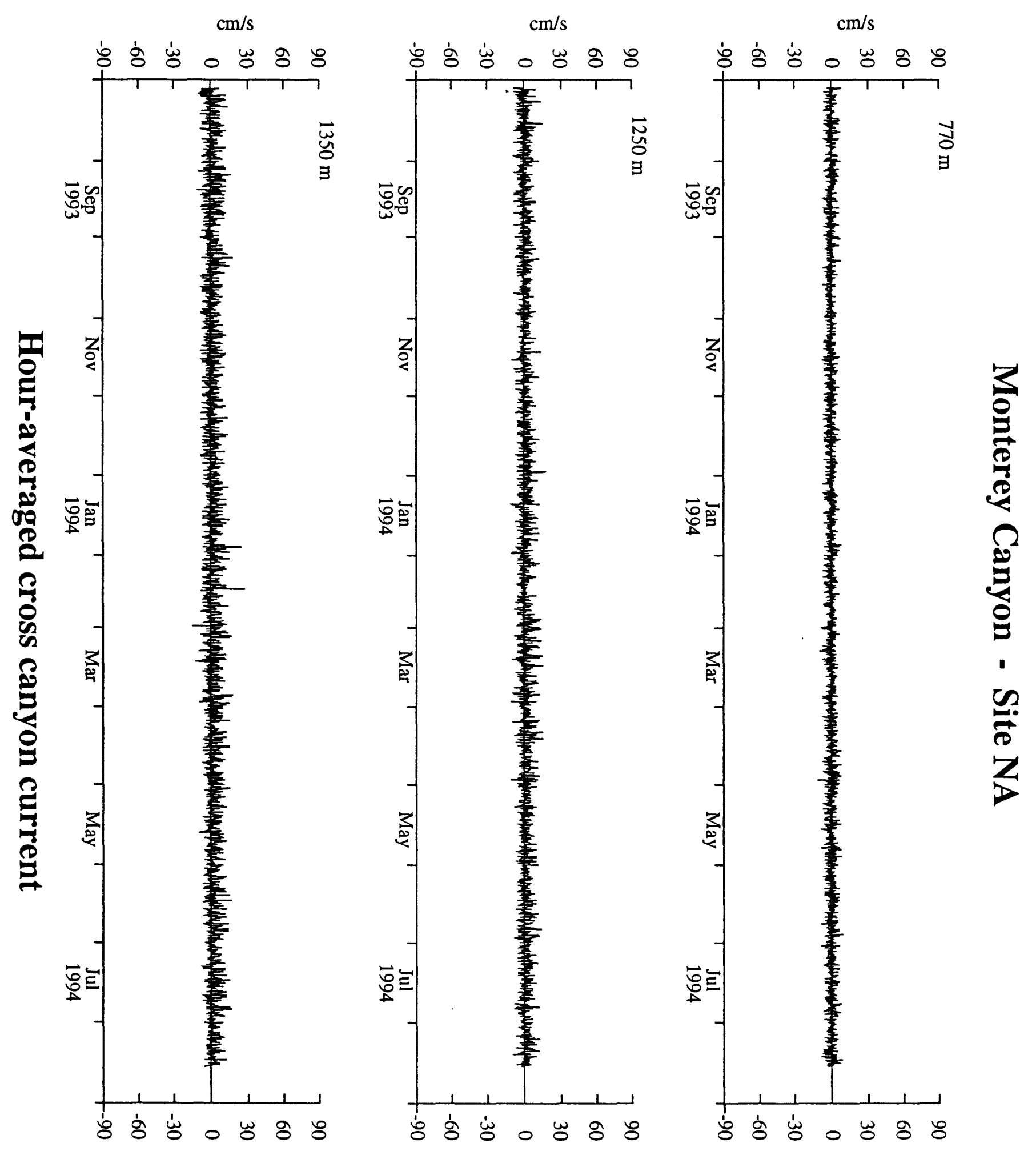


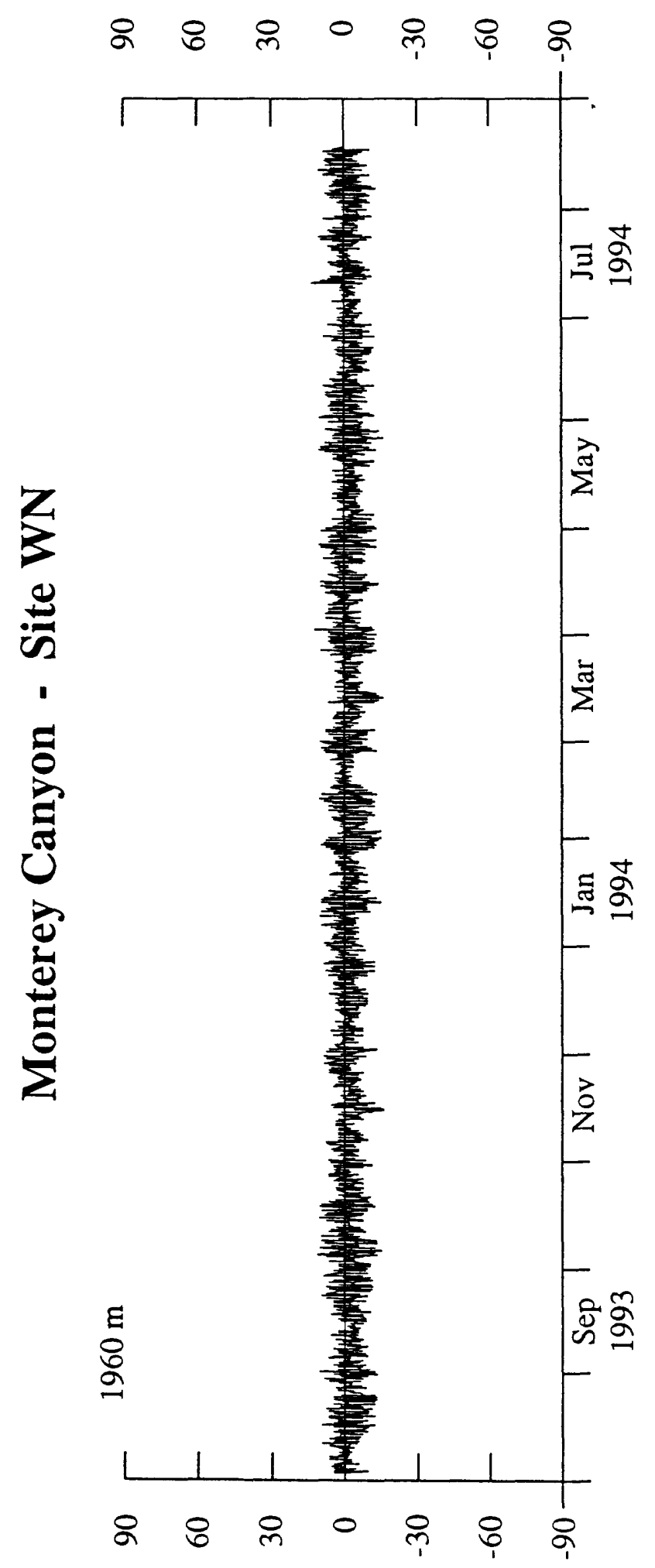

s/us

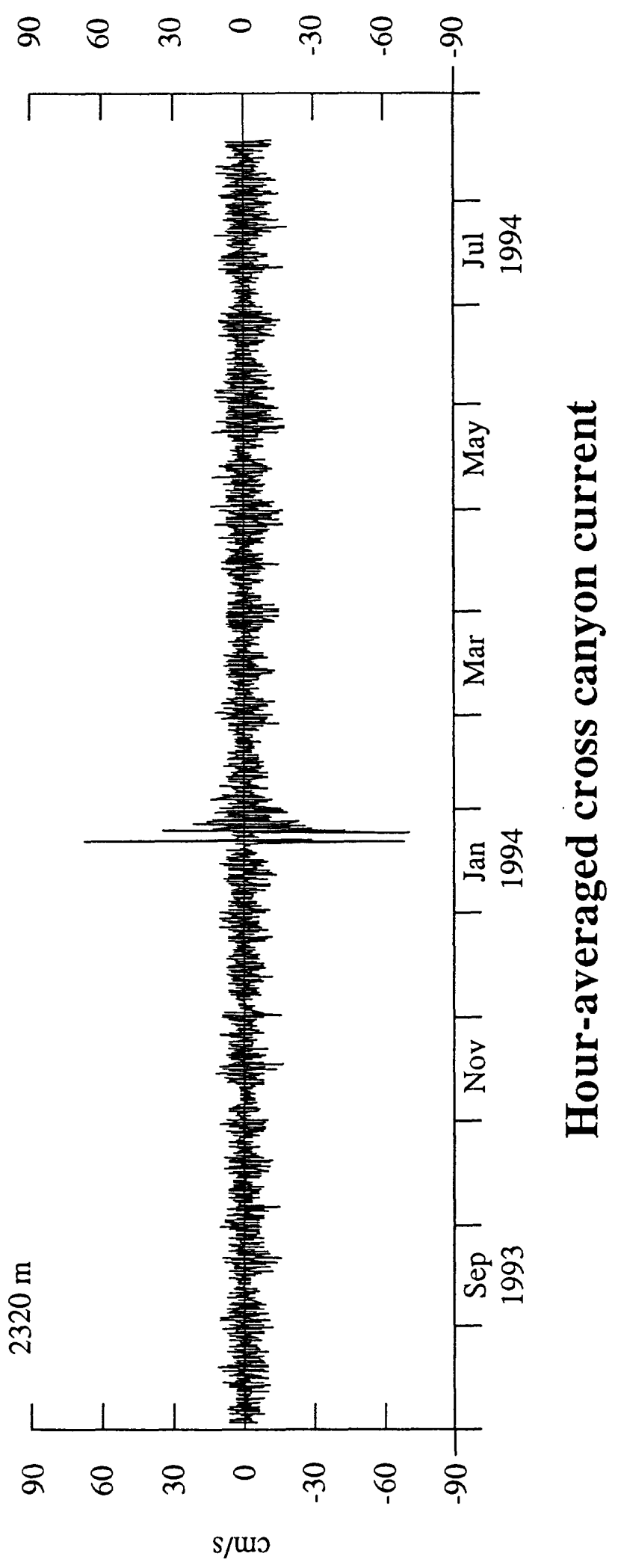


$\mathrm{cm} / \mathrm{s}$

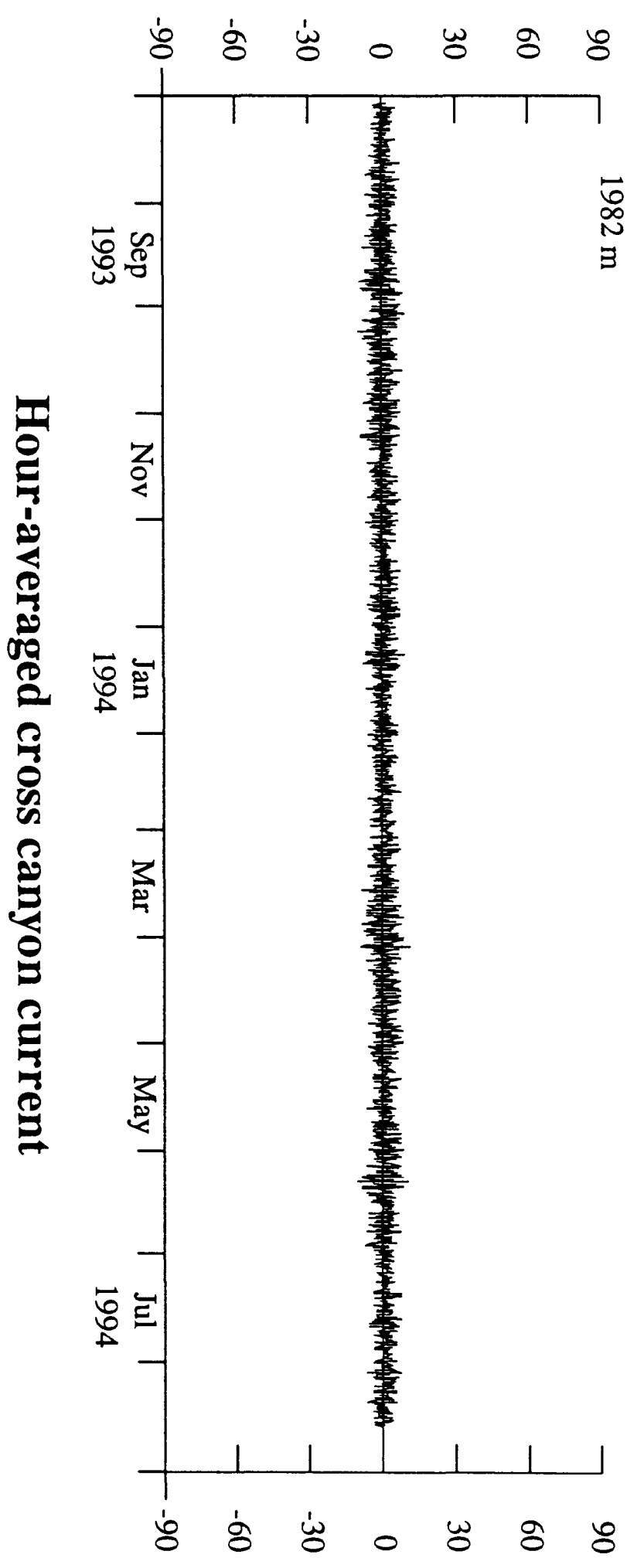

$\mathrm{cm} / \mathrm{s}$

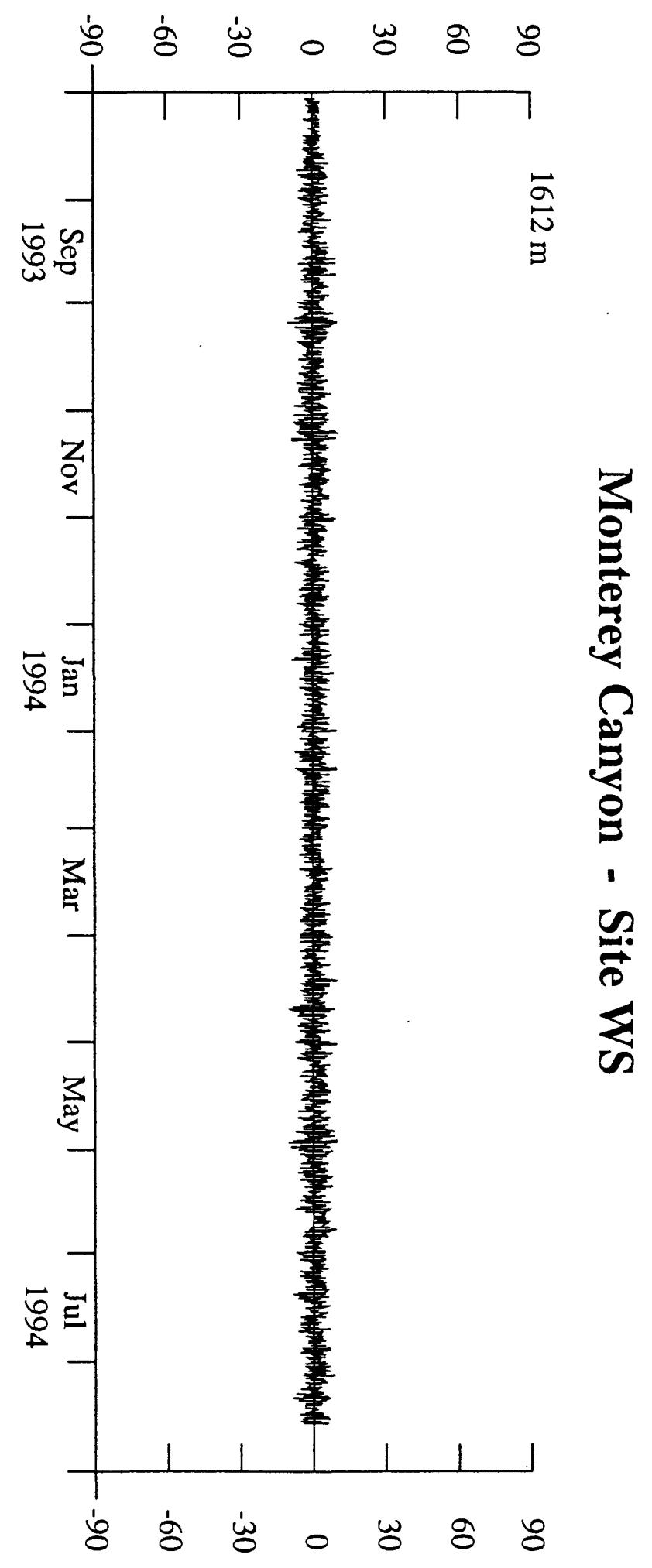




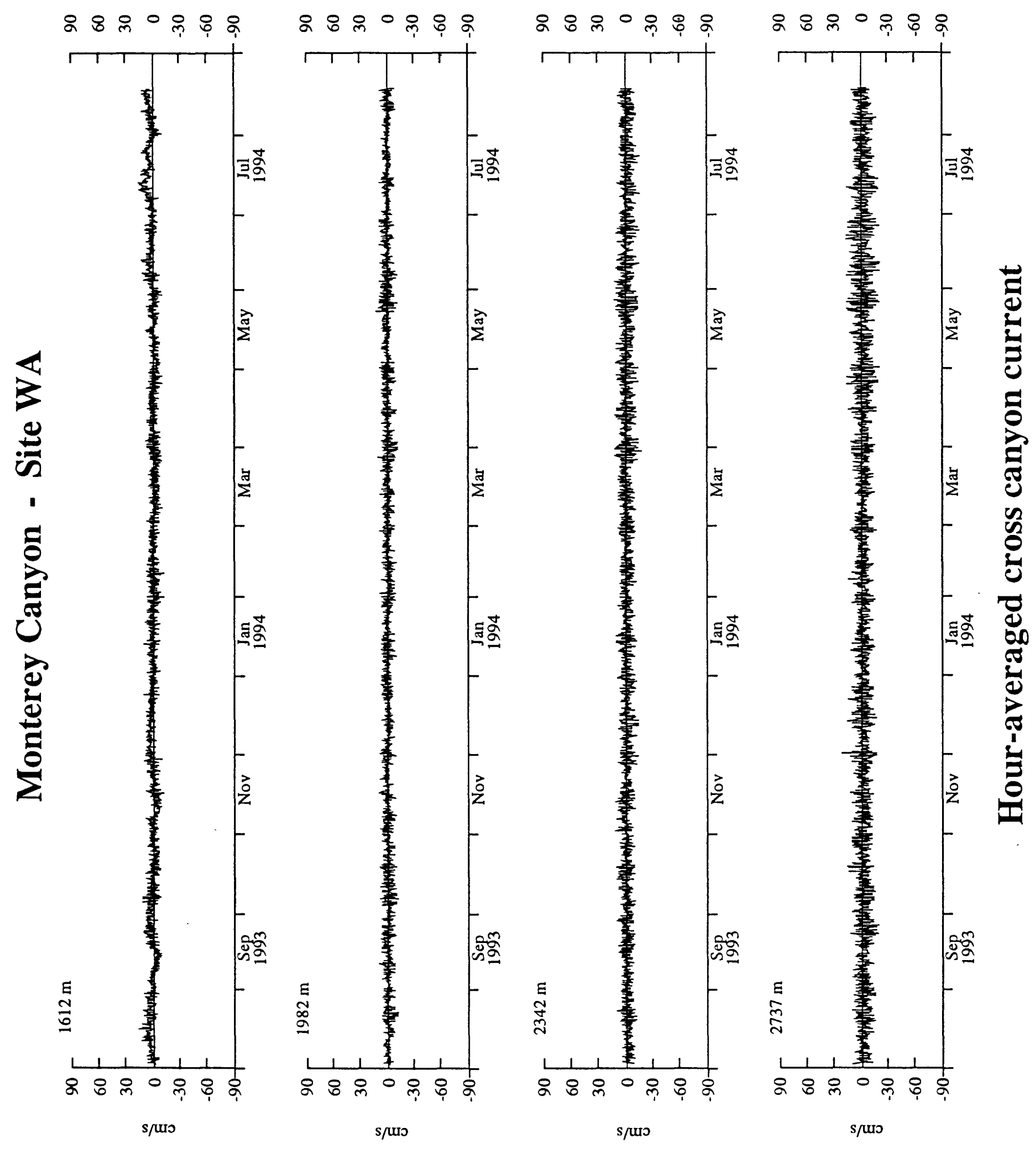




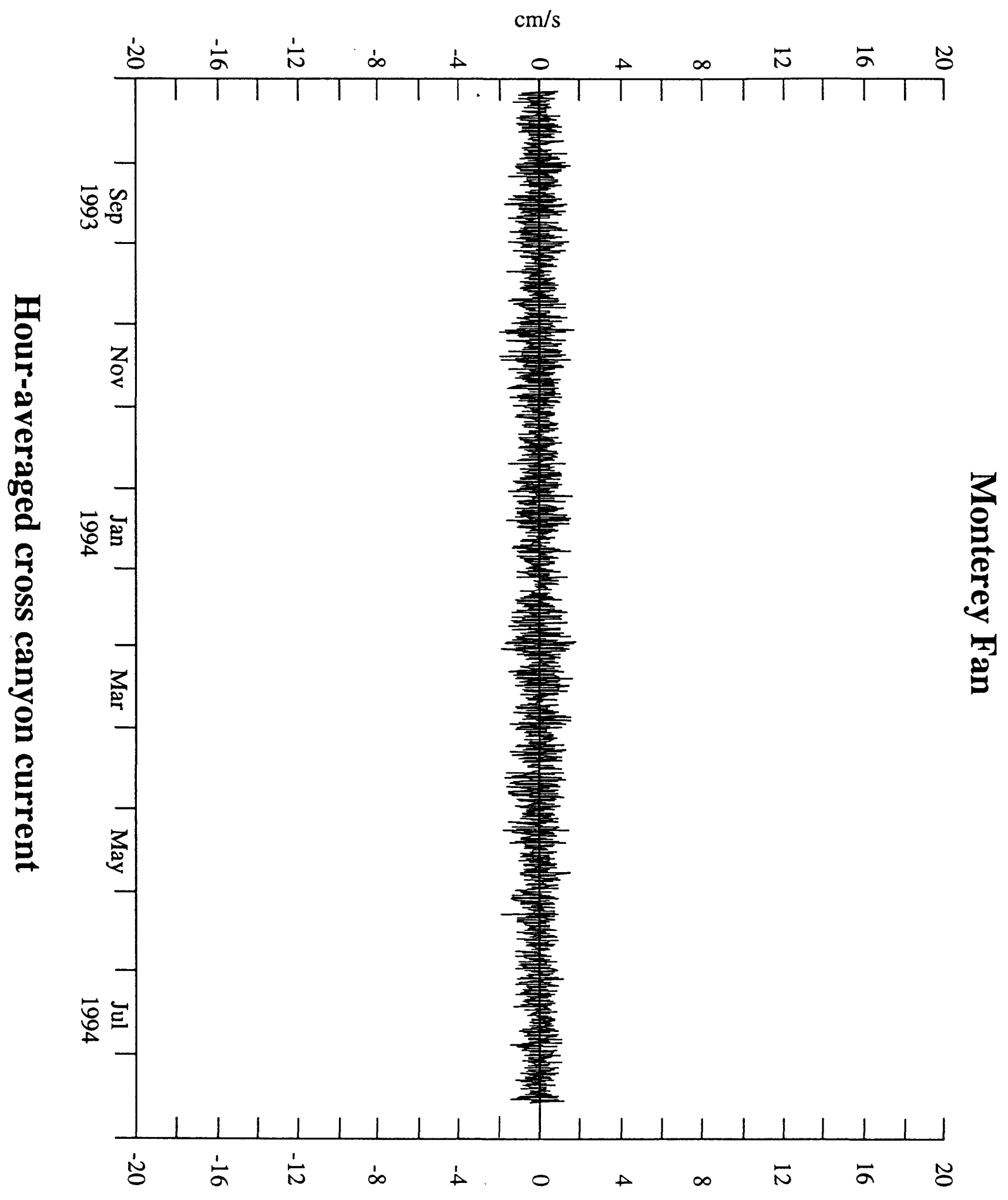



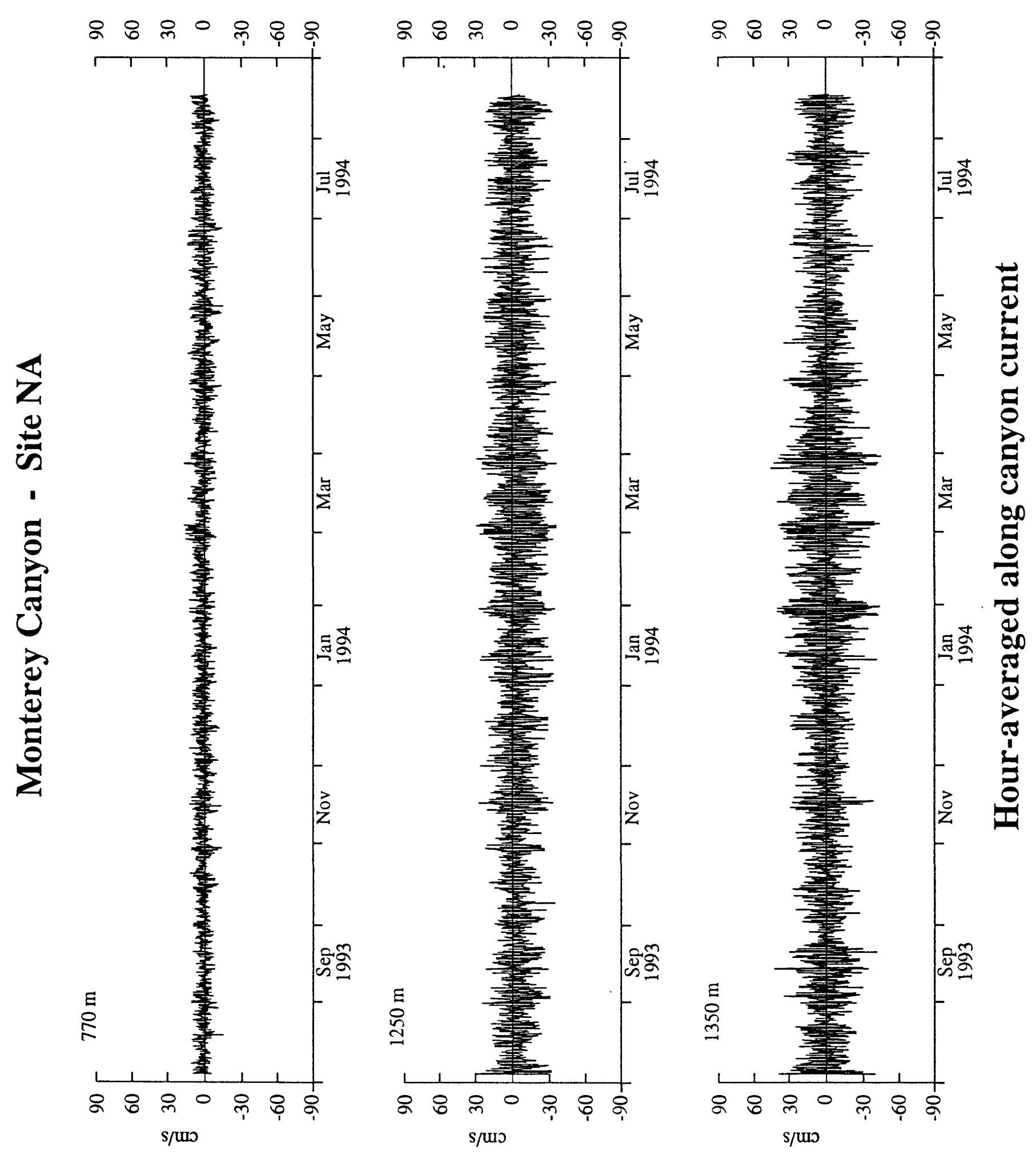
$\mathrm{cm} / \mathrm{s}$

த் த்

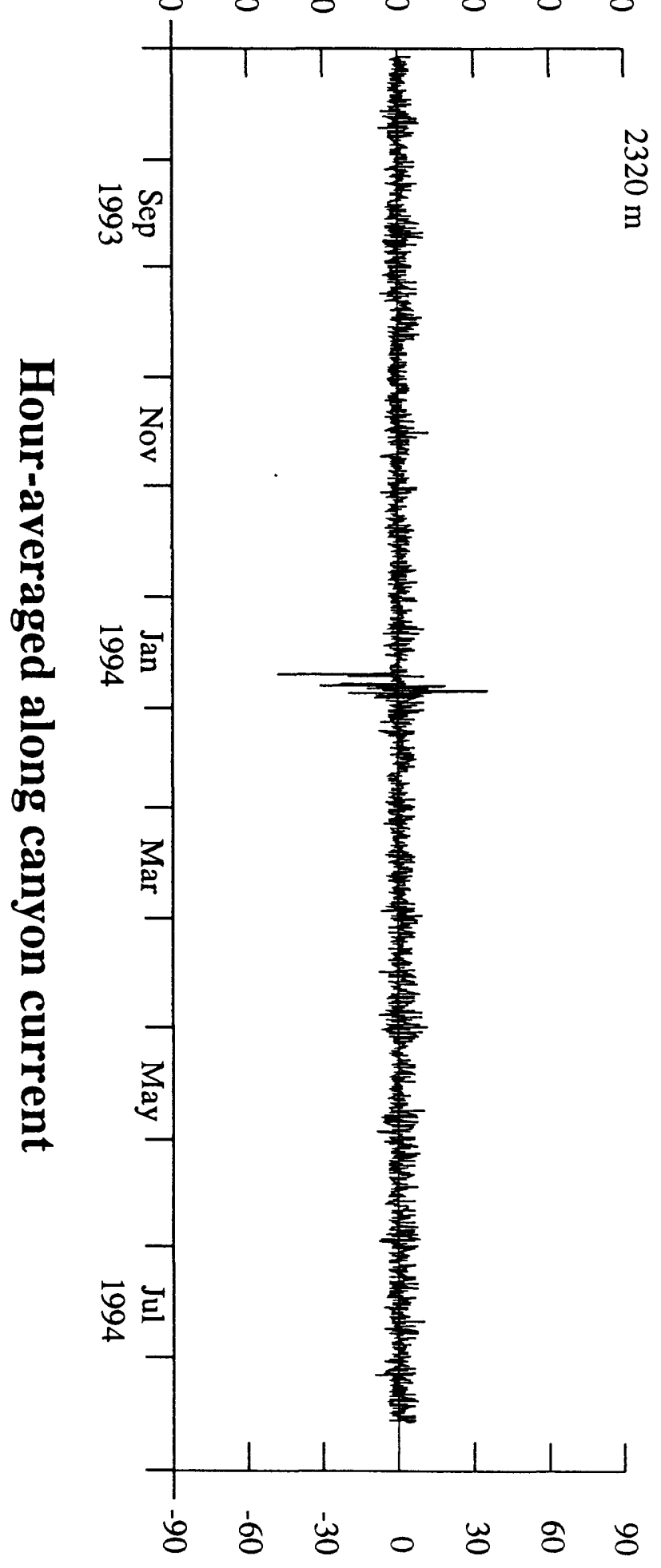

$\mathrm{cm} / \mathrm{s}$

ஆ் $\dot{8}$ ப்

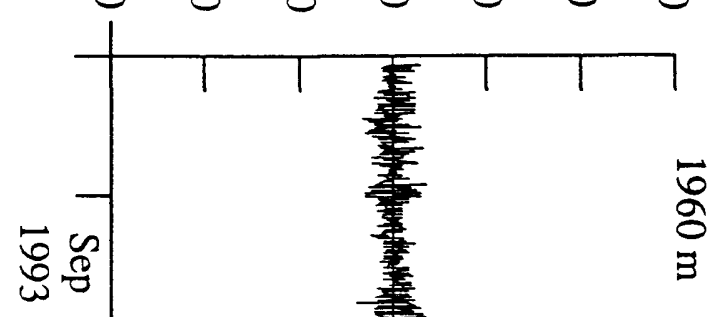

उ

年

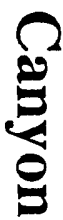

ह 

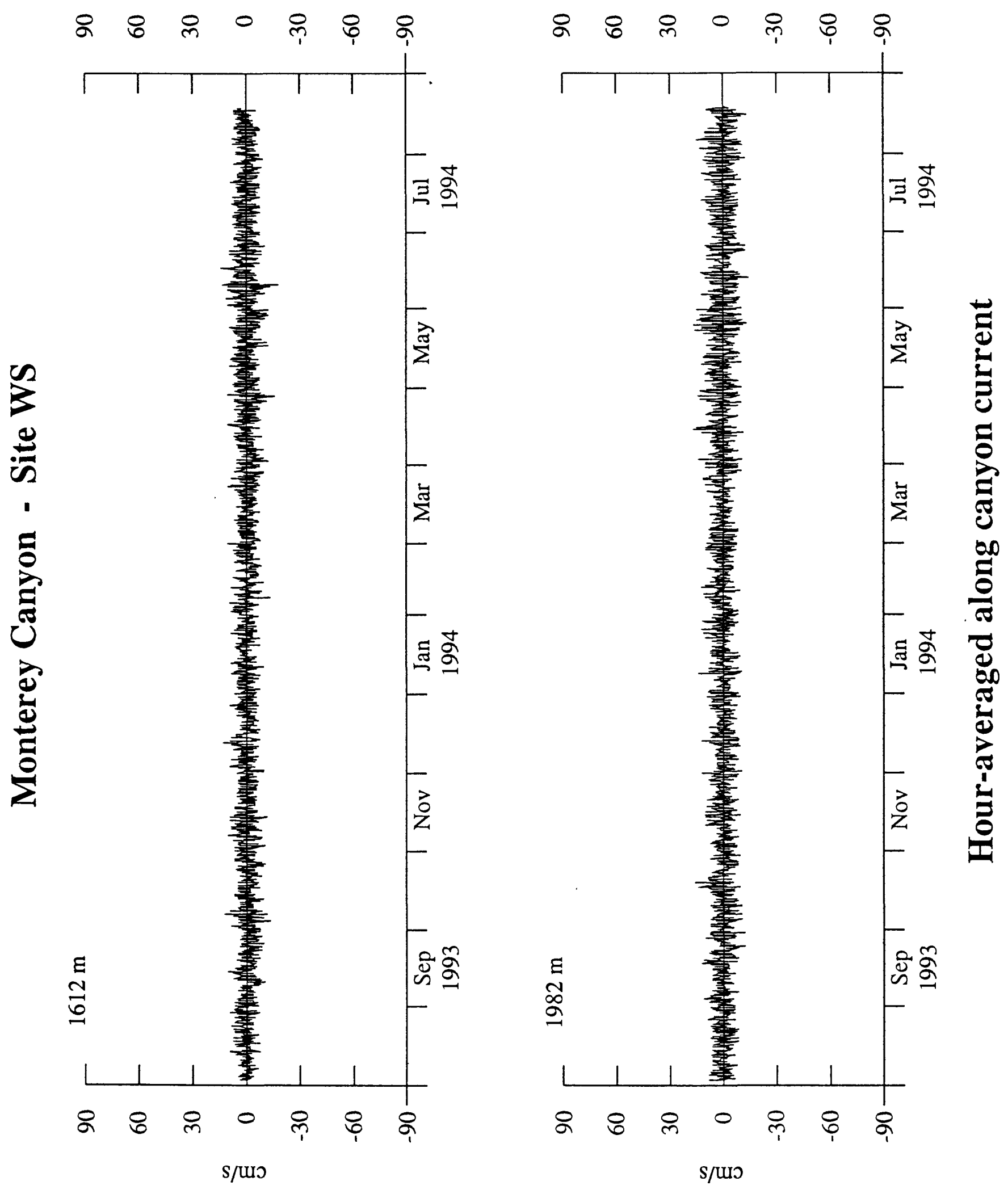


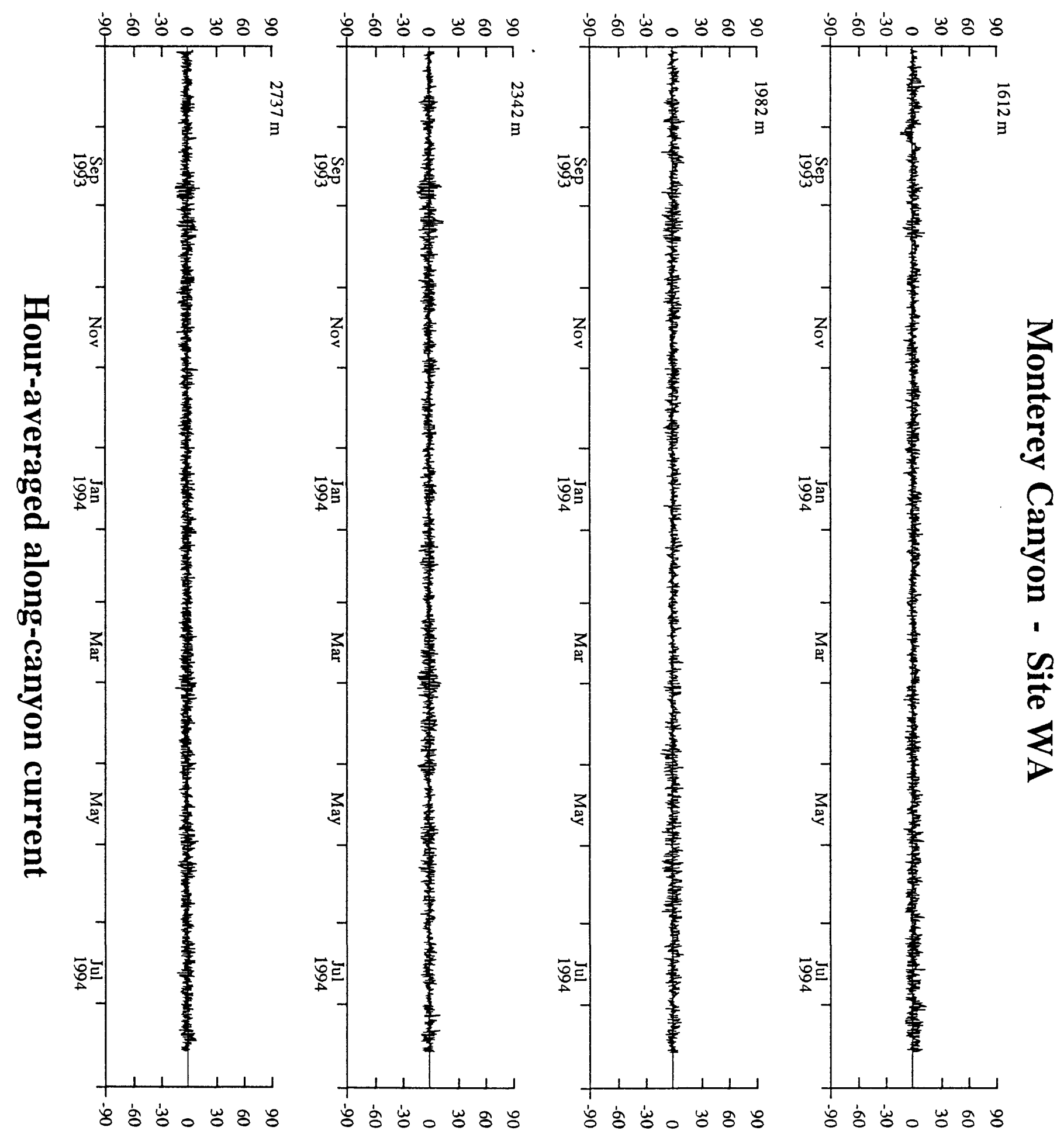




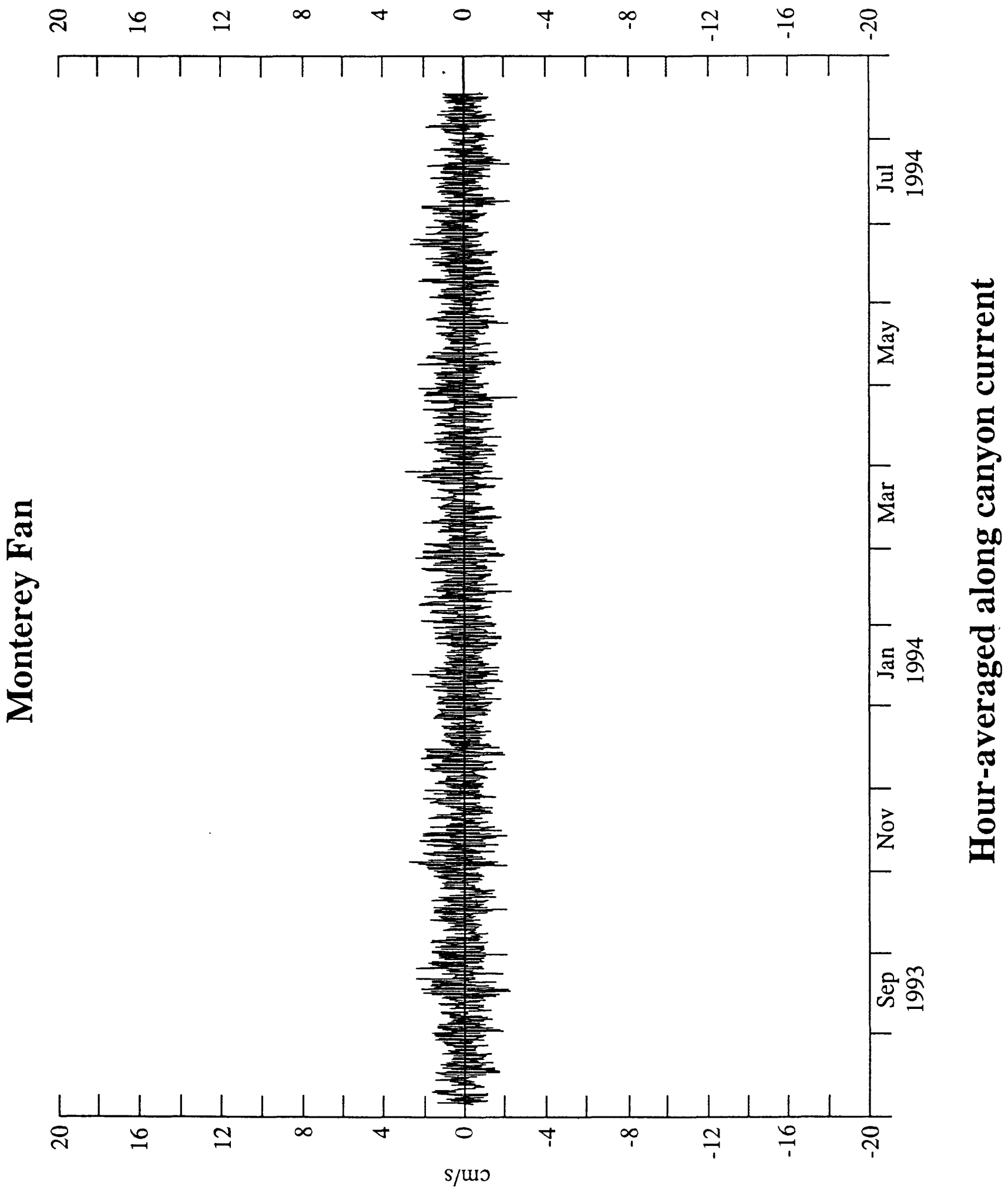


$\mathrm{cm} / \mathrm{s} \quad \mathrm{cm} / \mathrm{s} \quad \mathrm{cm} / \mathrm{s}$

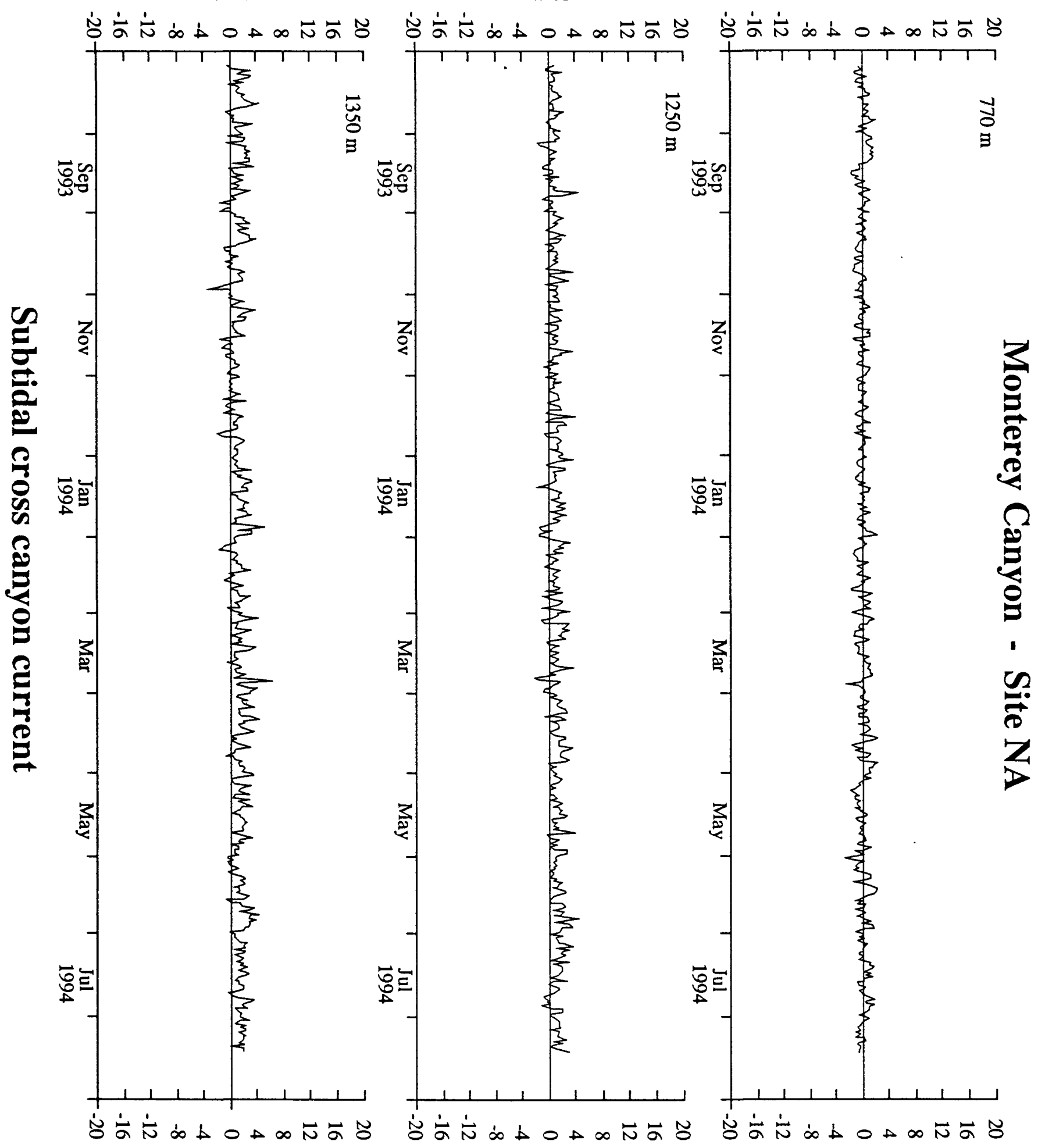


ㅇำำ

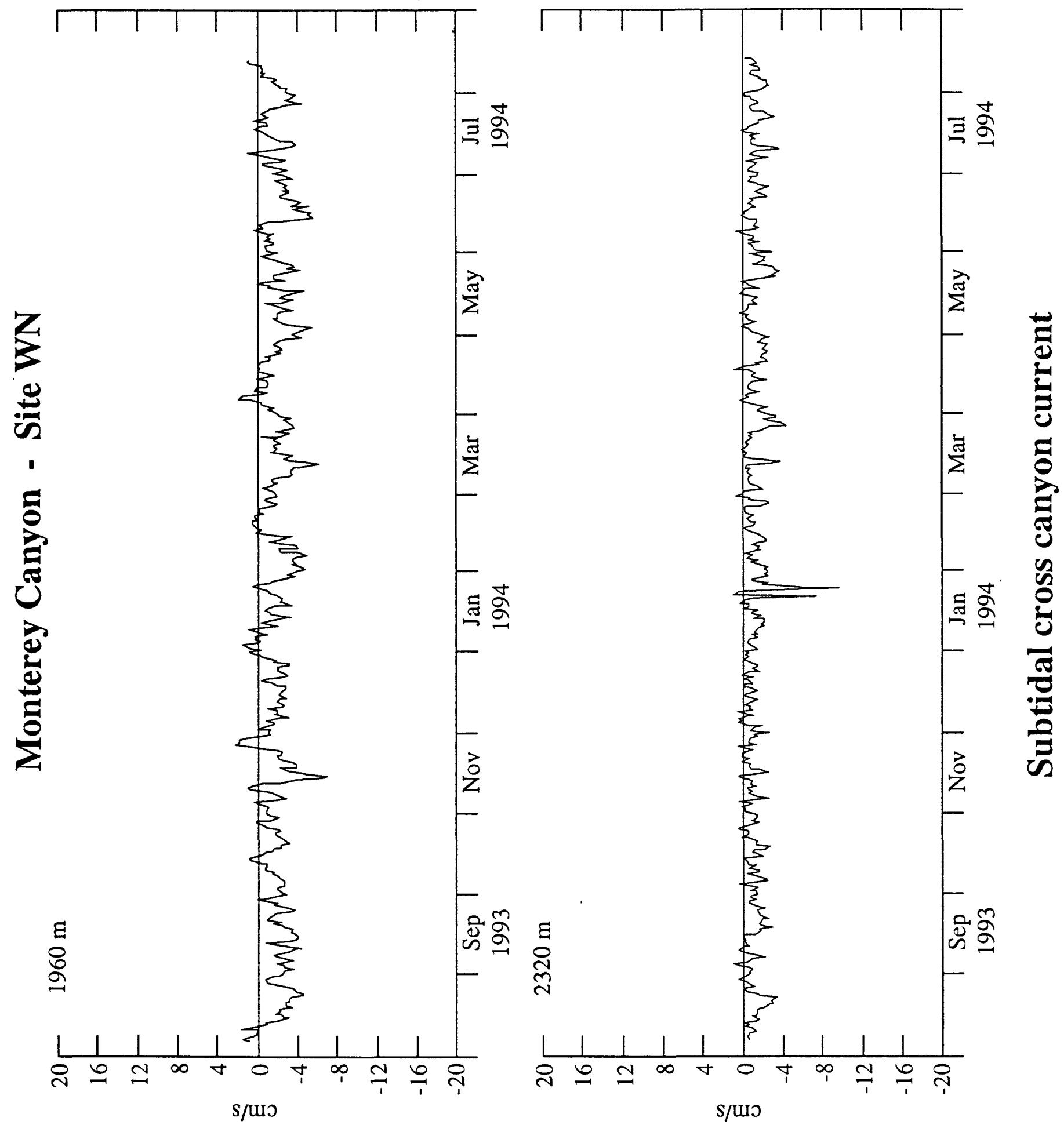




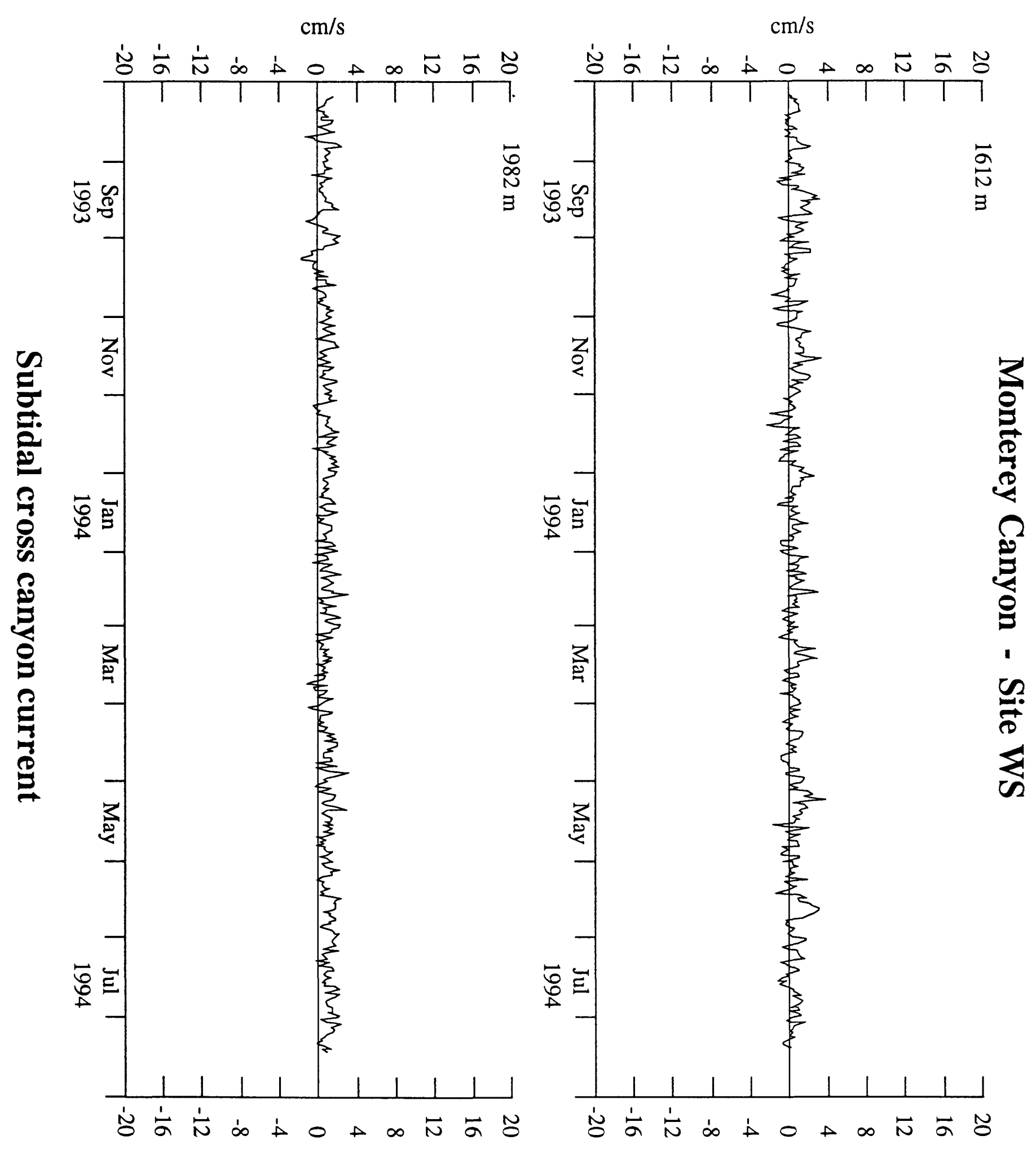




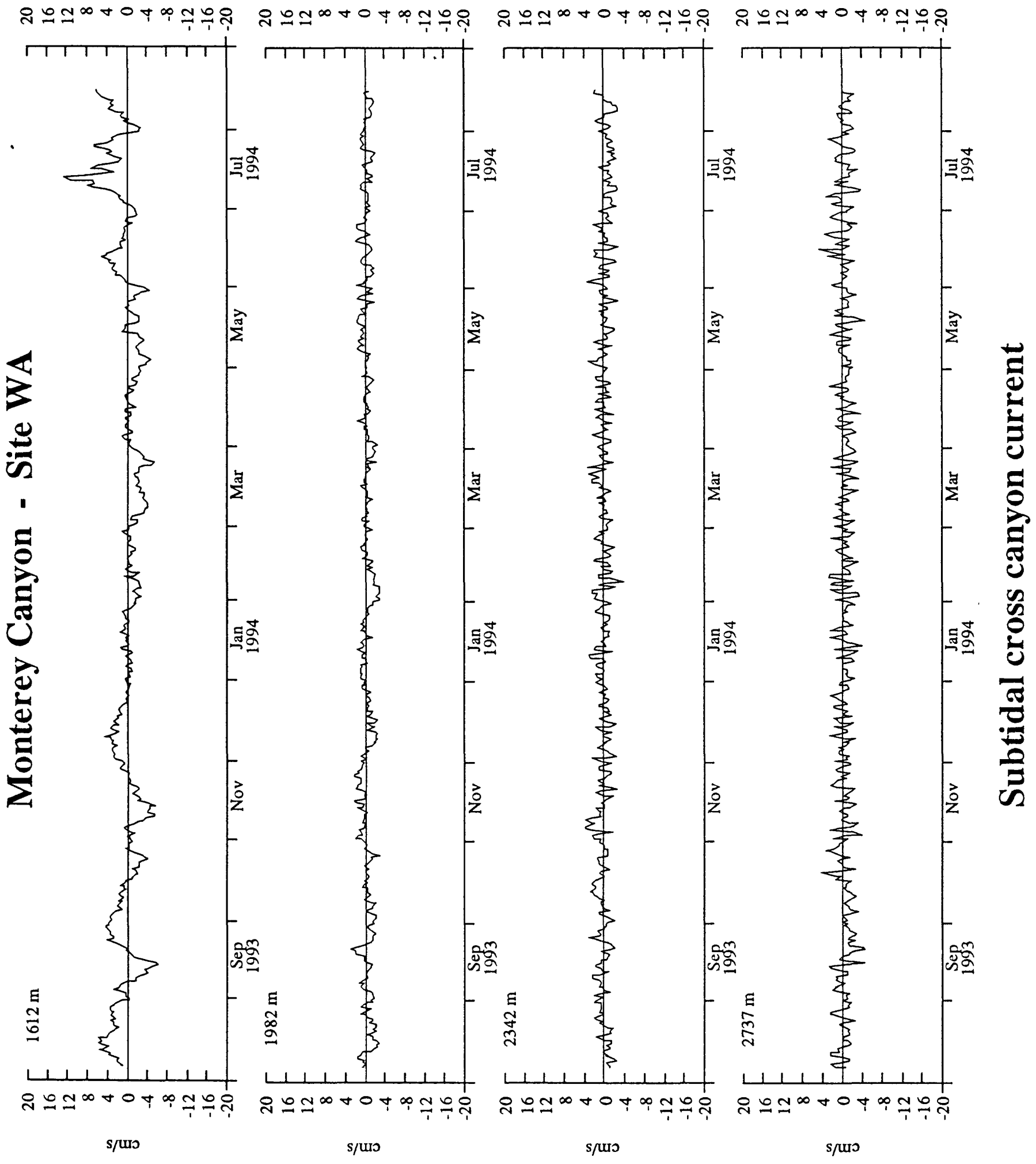




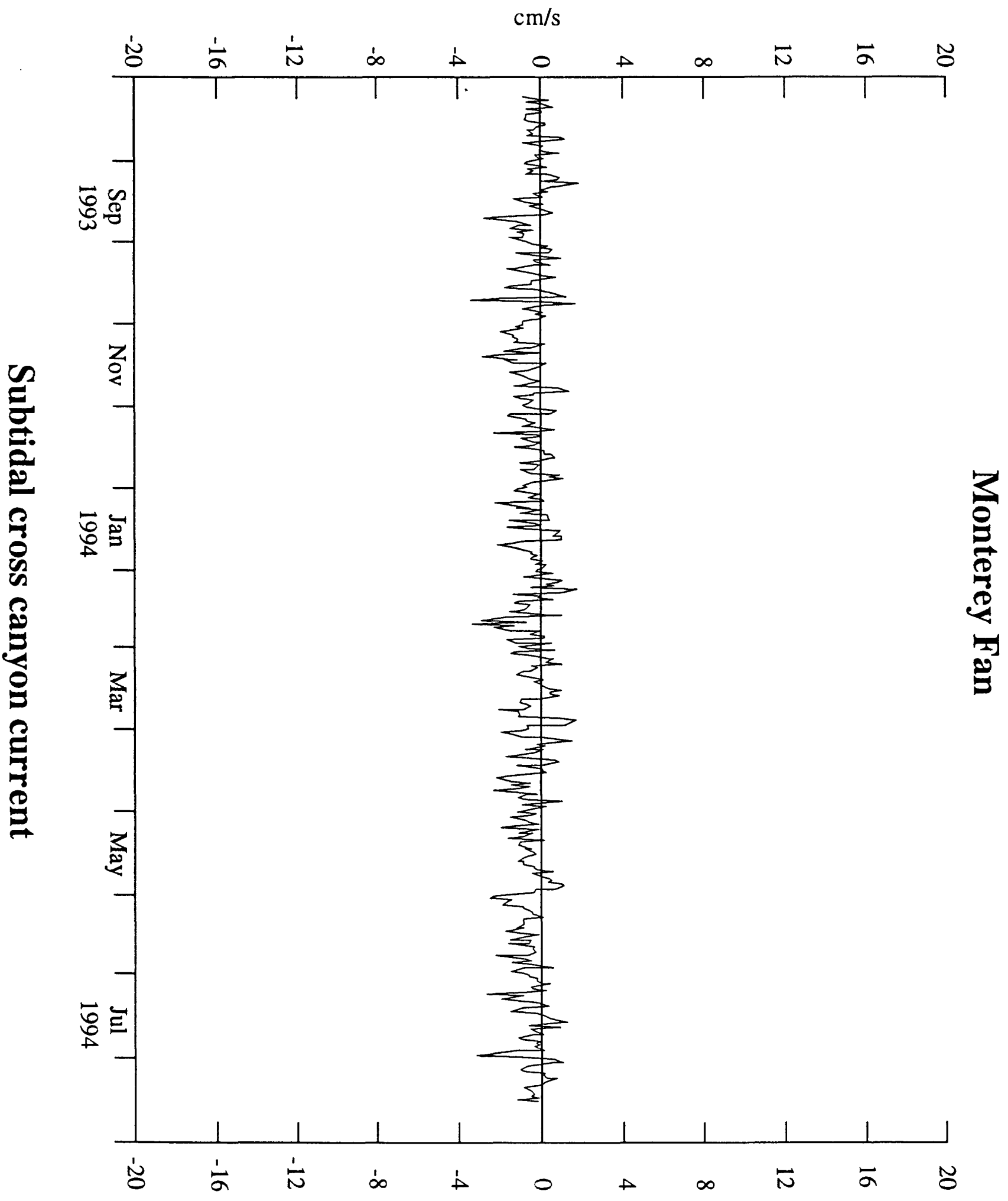




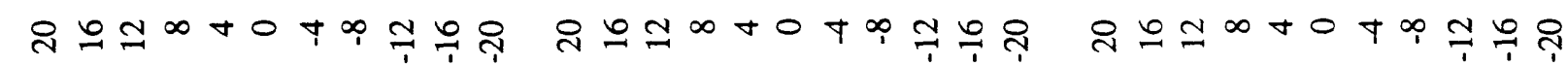

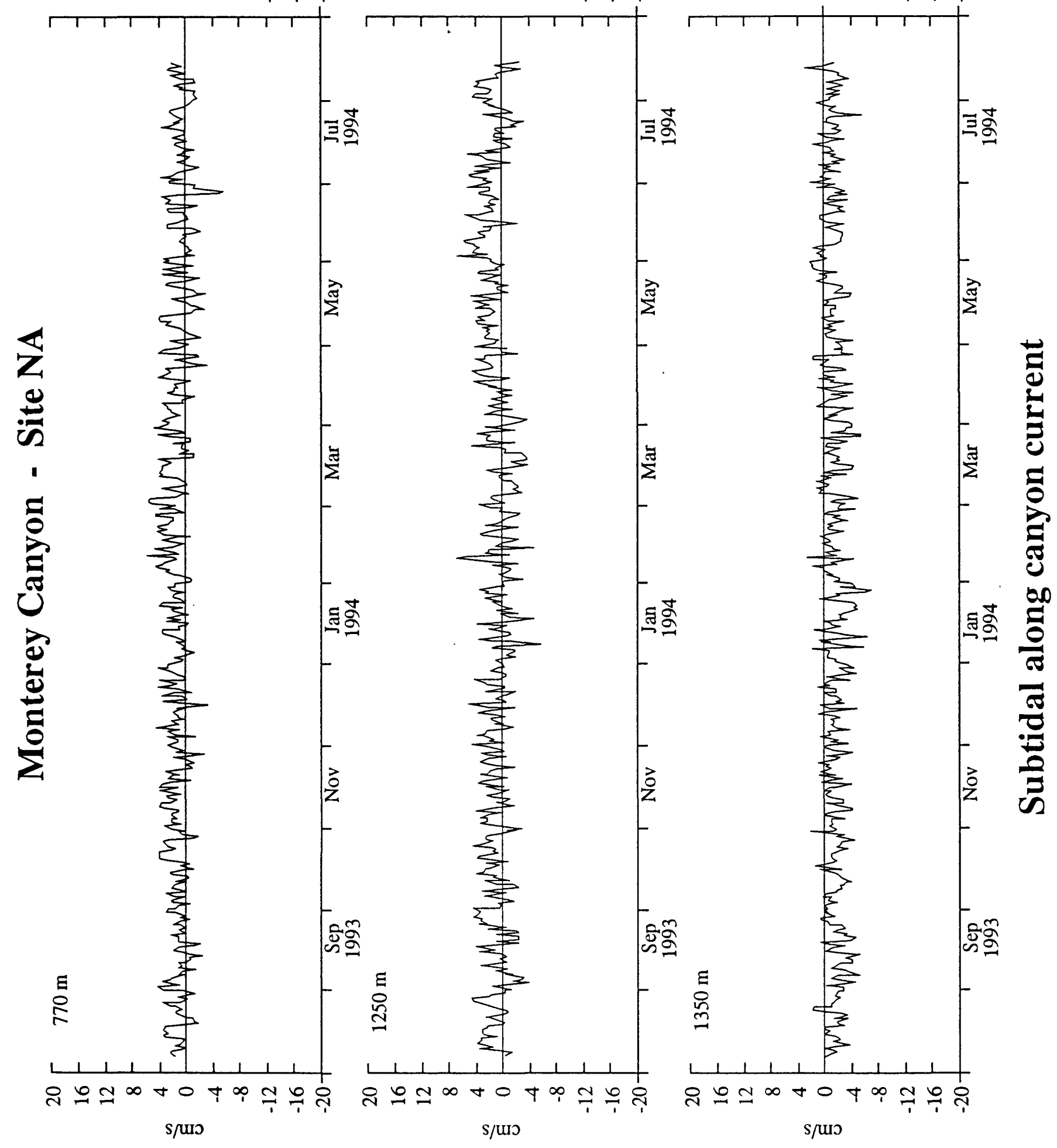




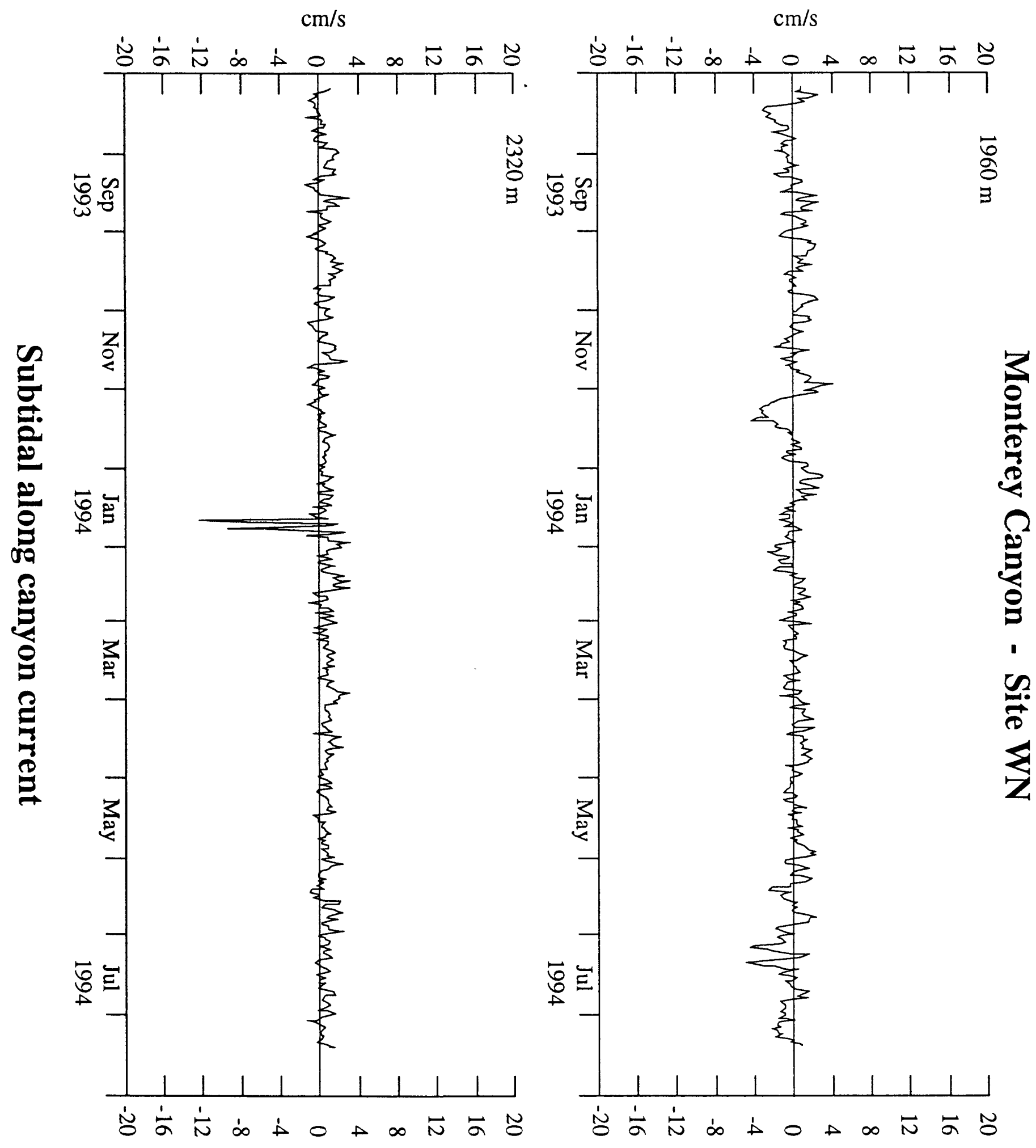




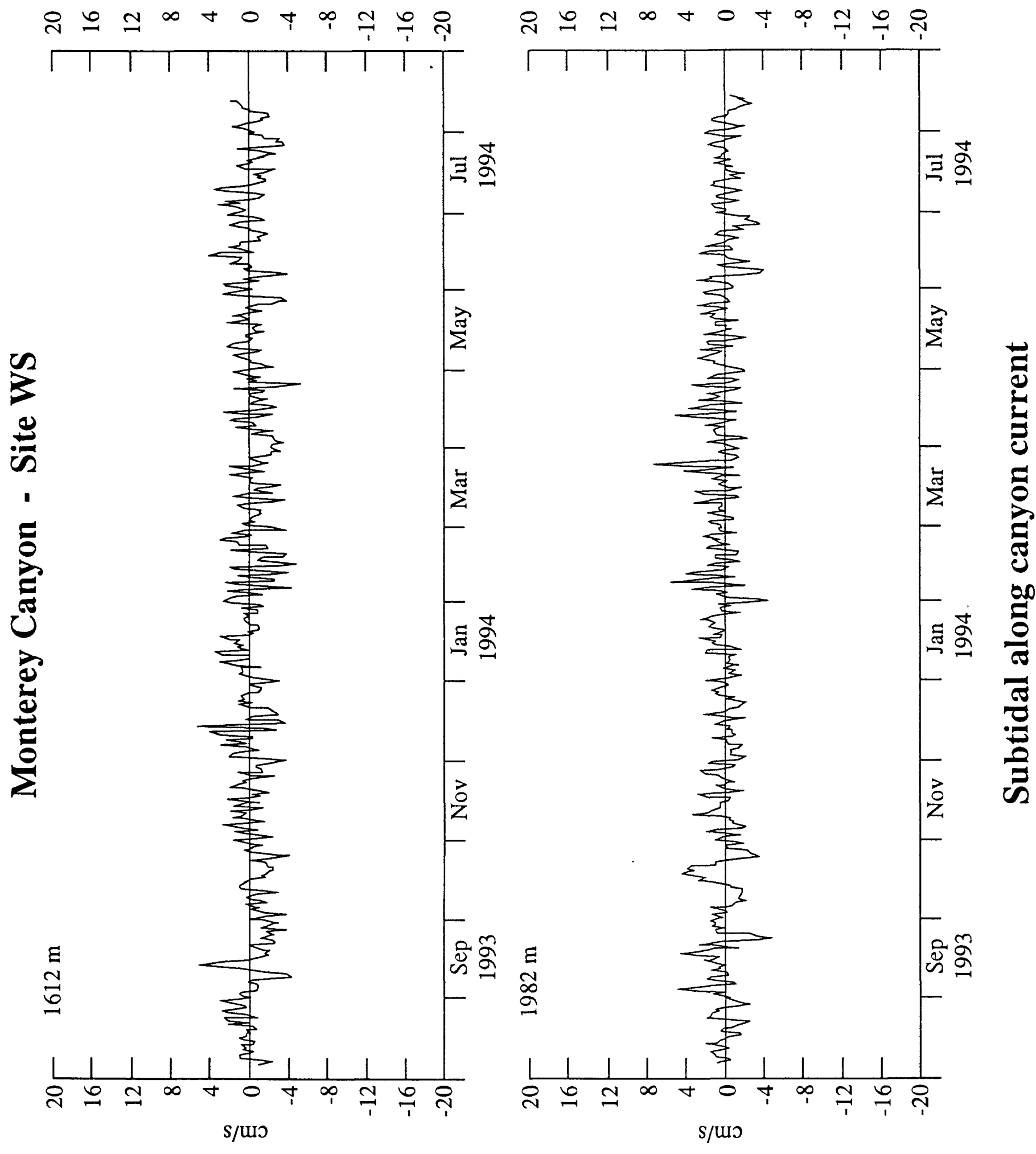


$\mathrm{cm} / \mathrm{s}$

$\mathrm{cm} / \mathrm{s}$

$\mathrm{cm} / \mathrm{s}$

$\mathrm{cm} / \mathrm{s}$

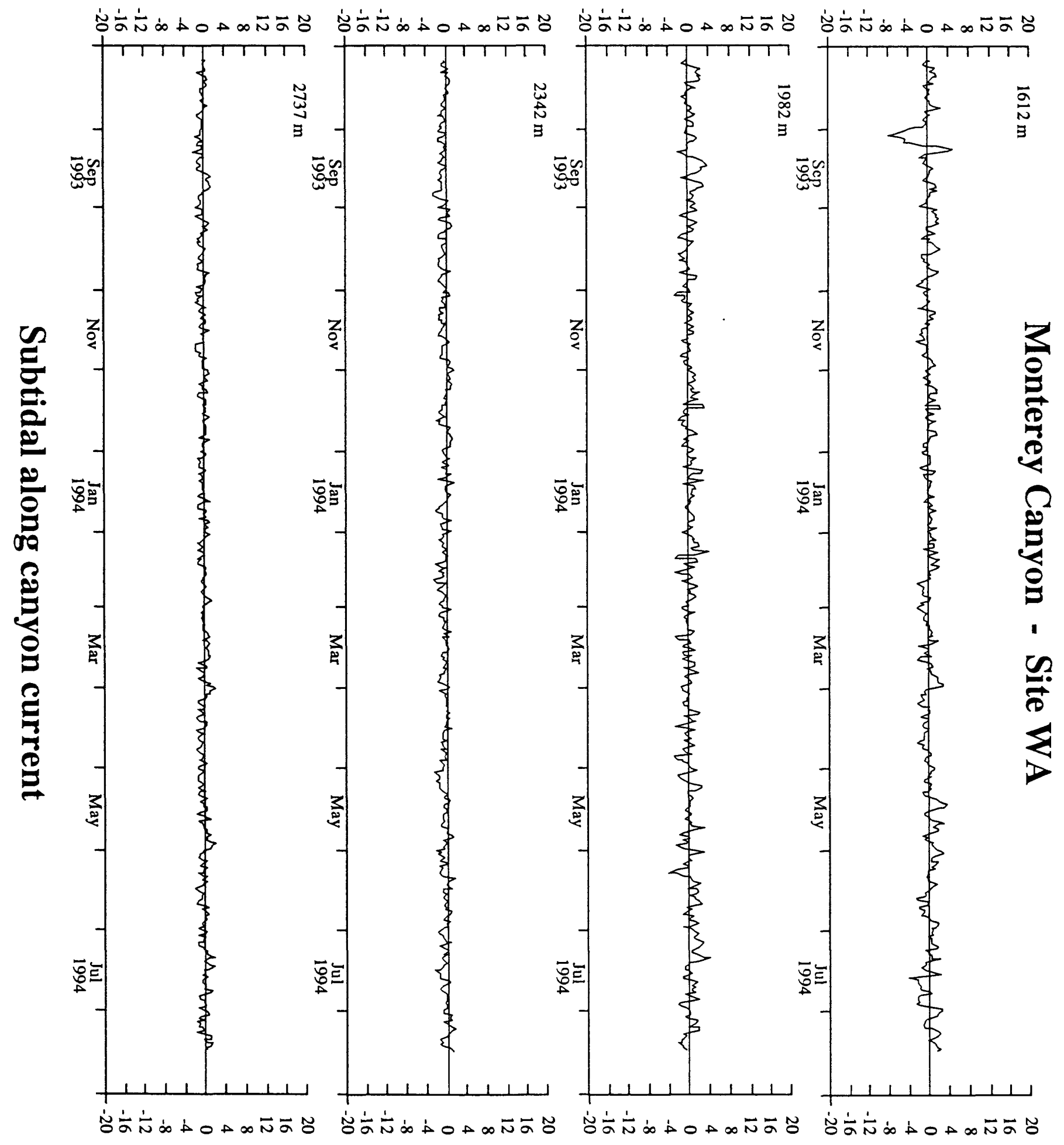




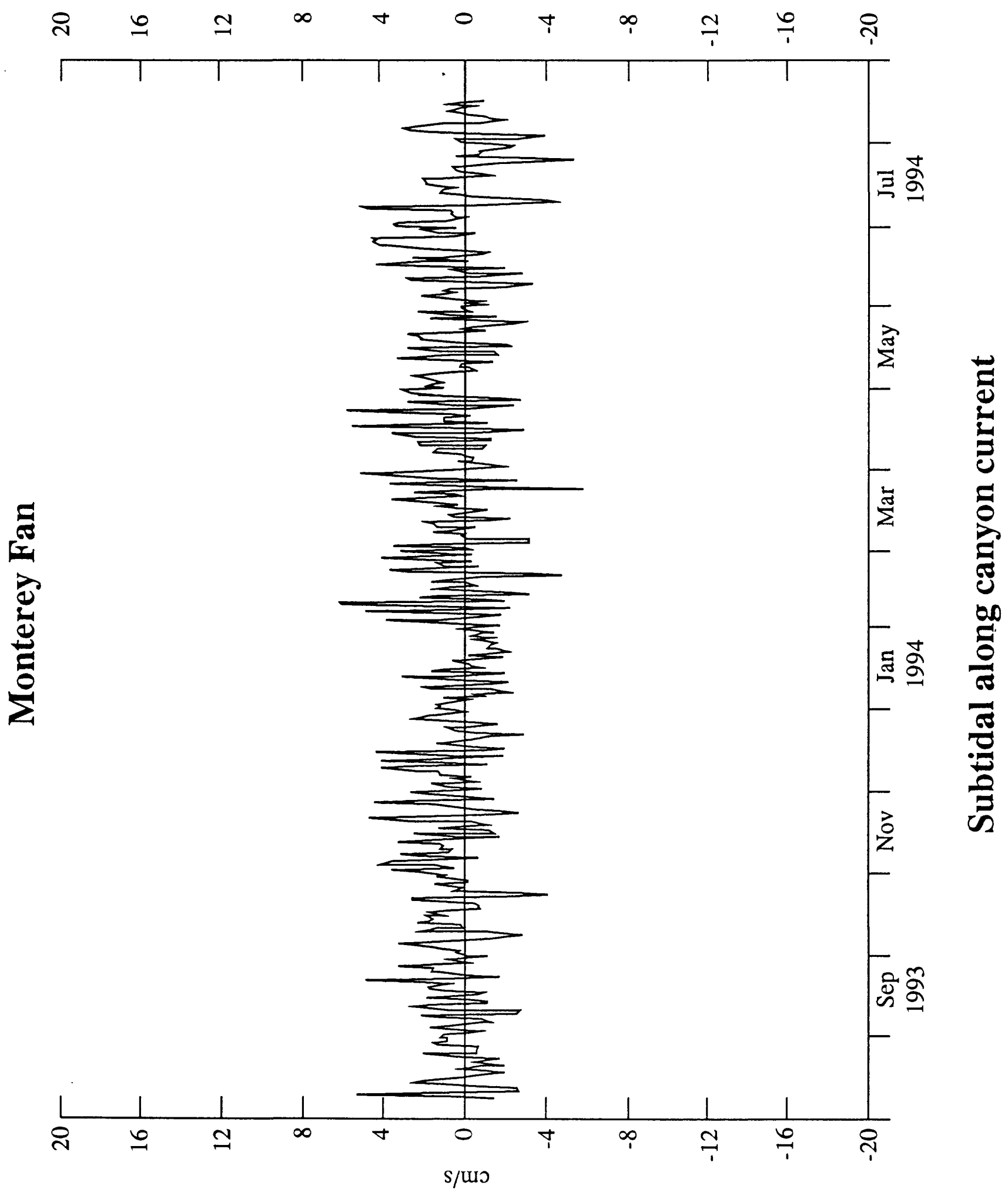




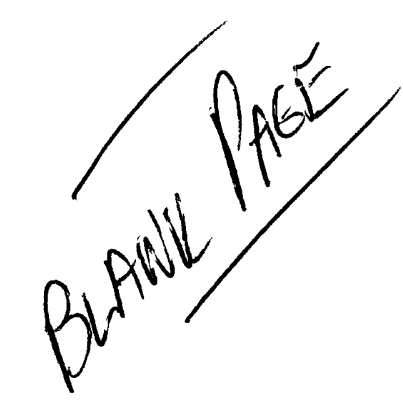




\section{Appendix C - Subtidal current vectors}

Plots of subtidal current vectors

$\mathrm{C} 1-\mathrm{C} 5$ 


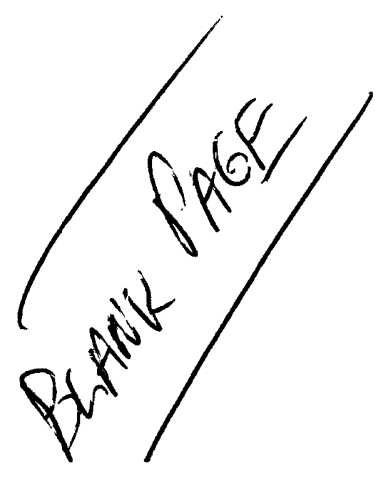




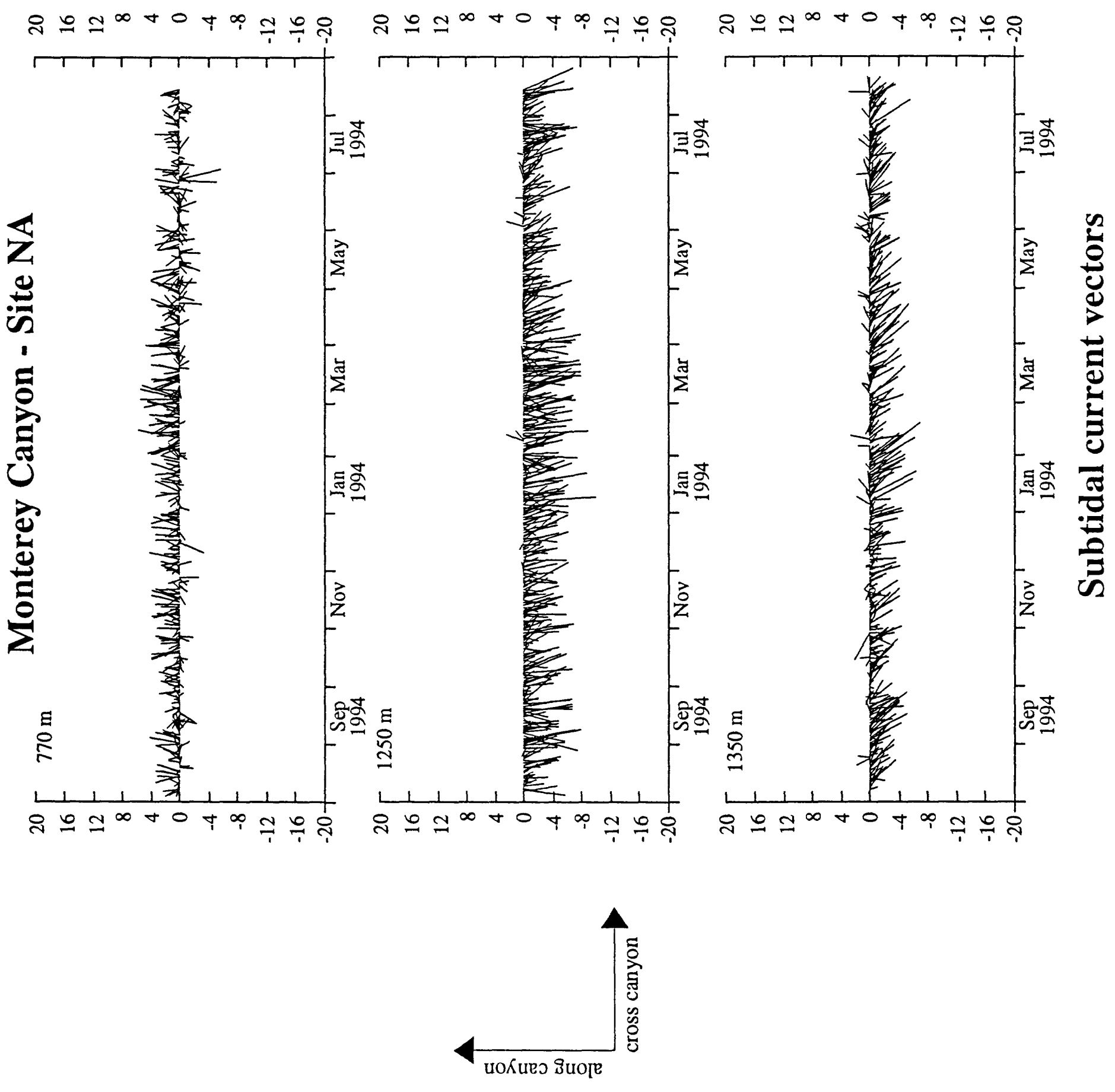

C-1 

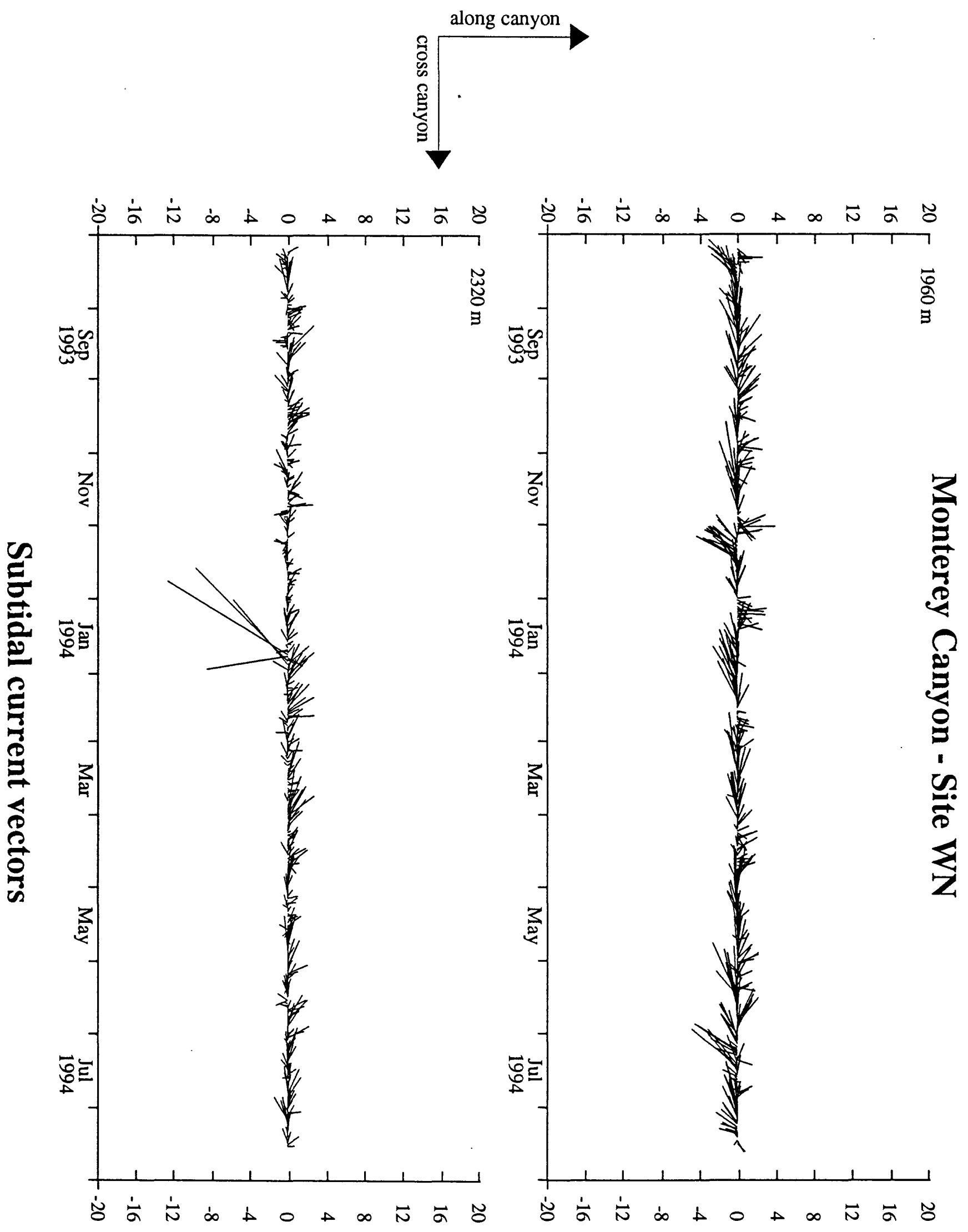

C-2 

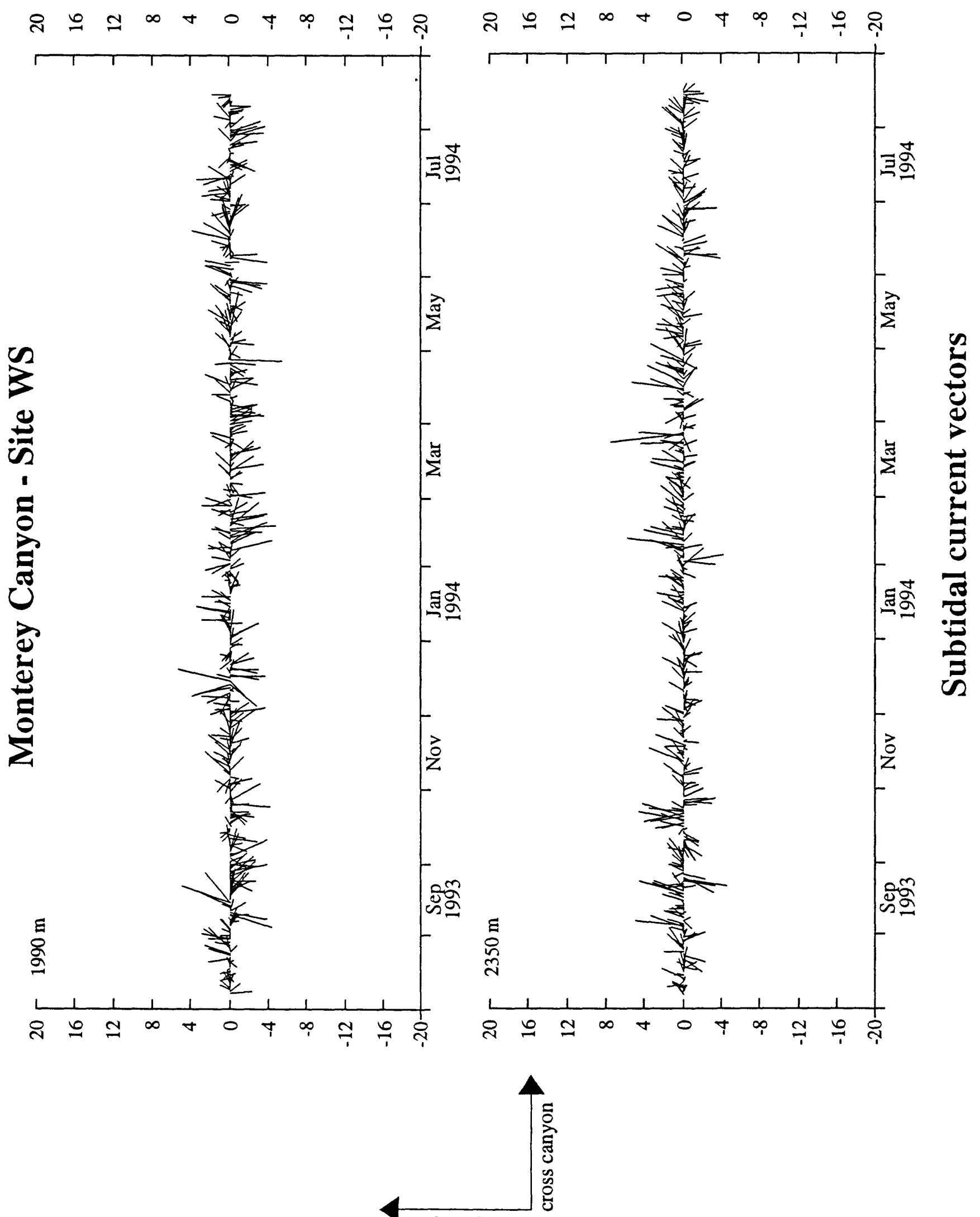

uoKuro 3uore

C-3 

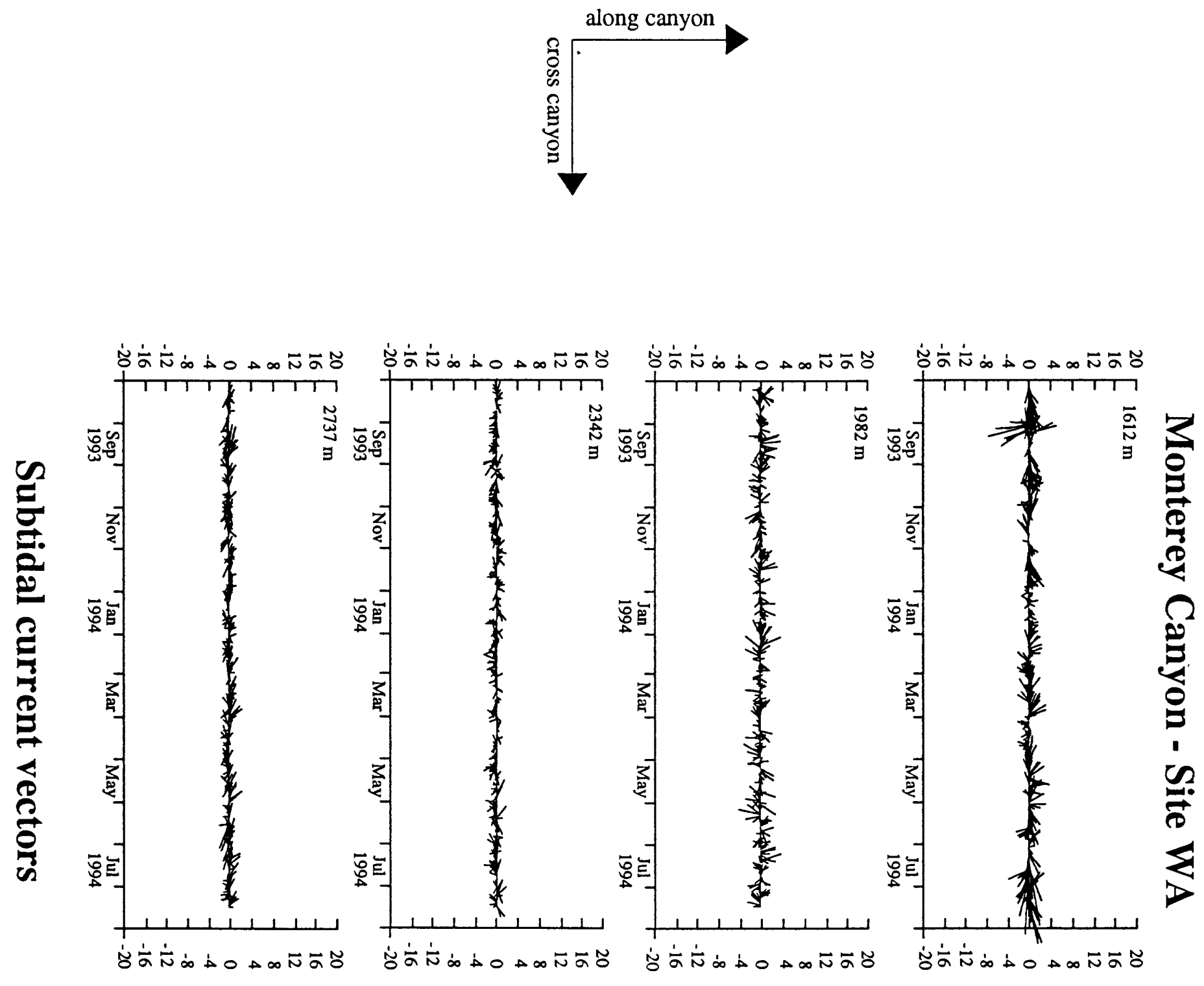

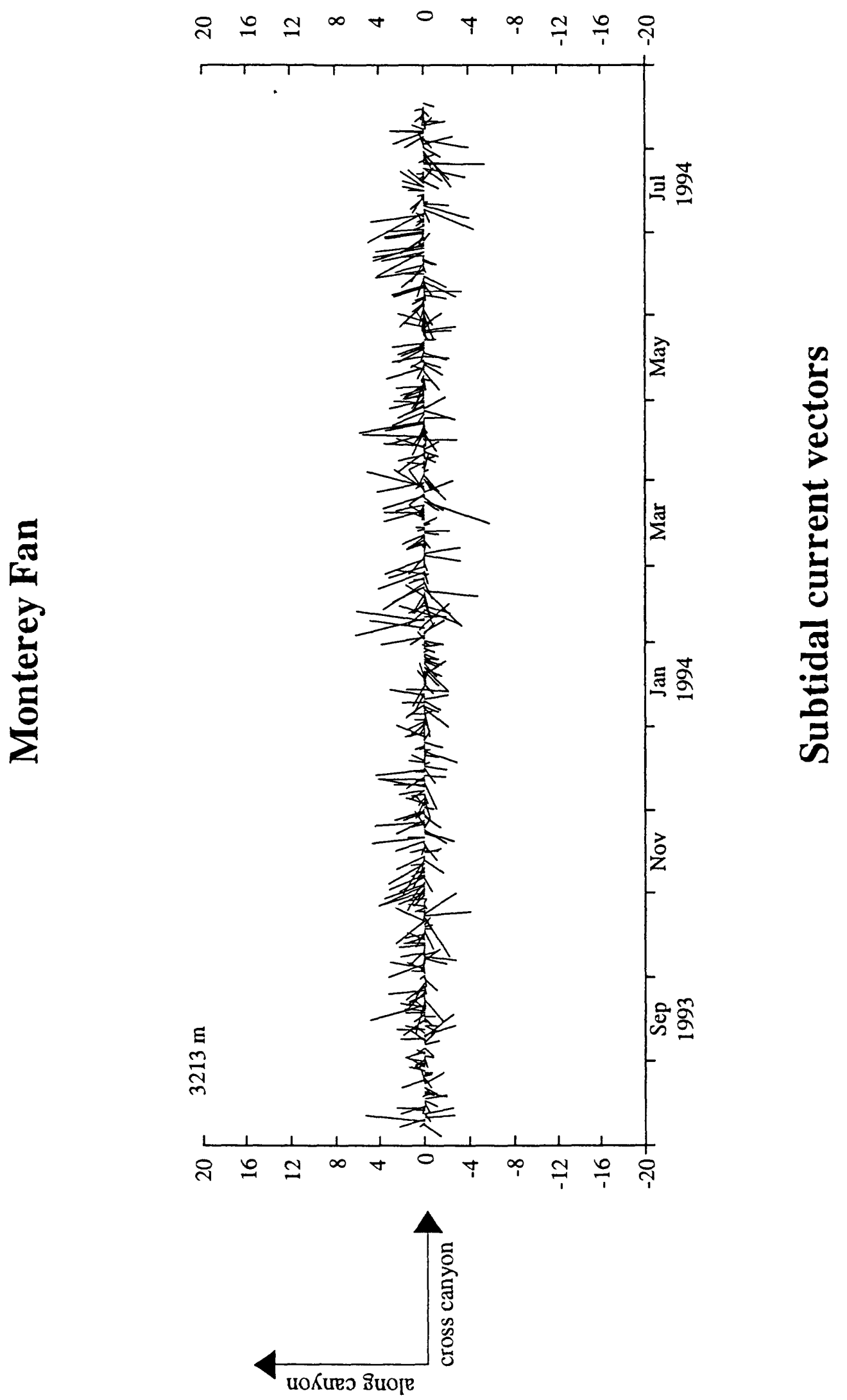

C-5 


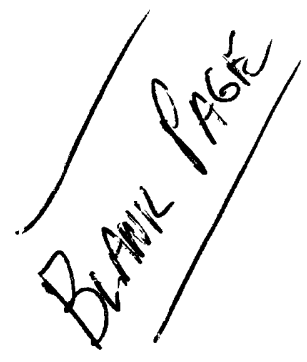




\begin{tabular}{|l|ccc|c|c|}
\hline Site & Mooring & $\begin{array}{c}\text { Sensor } \\
\text { Depth } \\
(\mathrm{m})\end{array}$ & $\begin{array}{c}\text { Start time } \\
\text { GMT } \\
(\mathrm{M} / \mathrm{D} / \mathrm{Y})\end{array}$ & $\begin{array}{c}\text { Stop time } \\
\text { GMT } \\
(\mathrm{M} / \mathrm{D} / \mathrm{Y})\end{array}$ & $\begin{array}{c}\text { Piece length } \\
\text { hours }\end{array}$ \\
\hline NN & $422-1$ & 806 & $08 / 03 / 93$ & $08 / 17 / 94$ & 2112 \\
NA & $423-1$ & 1450 & $08 / 03 / 93$ & $08 / 17 / 94$ & 2112 \\
NA & $423-2$ & 1450 & $08 / 03 / 93$ & $08 / 17 / 94$ & 2112 \\
NA & $423-3$ & 1450 & $08 / 03 / 93$ & $08 / 17 / 94$ & 2112 \\
WN & $424-1$ & 2420 & $08 / 03 / 93$ & $08 / 17 / 94$ & 2112 \\
WN & $424-2$ & 2420 & $08 / 03 / 93$ & $08 / 17 / 94$ & 2112 \\
WS & $425-1$ & 2560 & $08 / 03 / 93$ & $08 / 18 / 94$ & 2112 \\
WS & $425-2$ & 2560 & $08 / 03 / 93$ & $08 / 18 / 94$ & 2112 \\
WA & $426-1$ & 2837 & $08 / 03 / 93$ & $08 / 18 / 94$ & 2112 \\
WA & $426-2$ & 2837 & $08 / 03 / 93$ & $08 / 18 / 94$ & 2112 \\
WA & $426-3$ & 2837 & $08 / 03 / 93$ & $08 / 18 / 94$ & 2112 \\
WA & $426-4$ & 2837 & $08 / 03 / 93$ & $08 / 18 / 94$ & 2112 \\
F & $427-1$ & 3223 & $08 / 05 / 93$ & $08 / 20 / 94$ & 2112 \\
\hline
\end{tabular}

Table D1. Dates and piece lengths used for the spectral plots. 


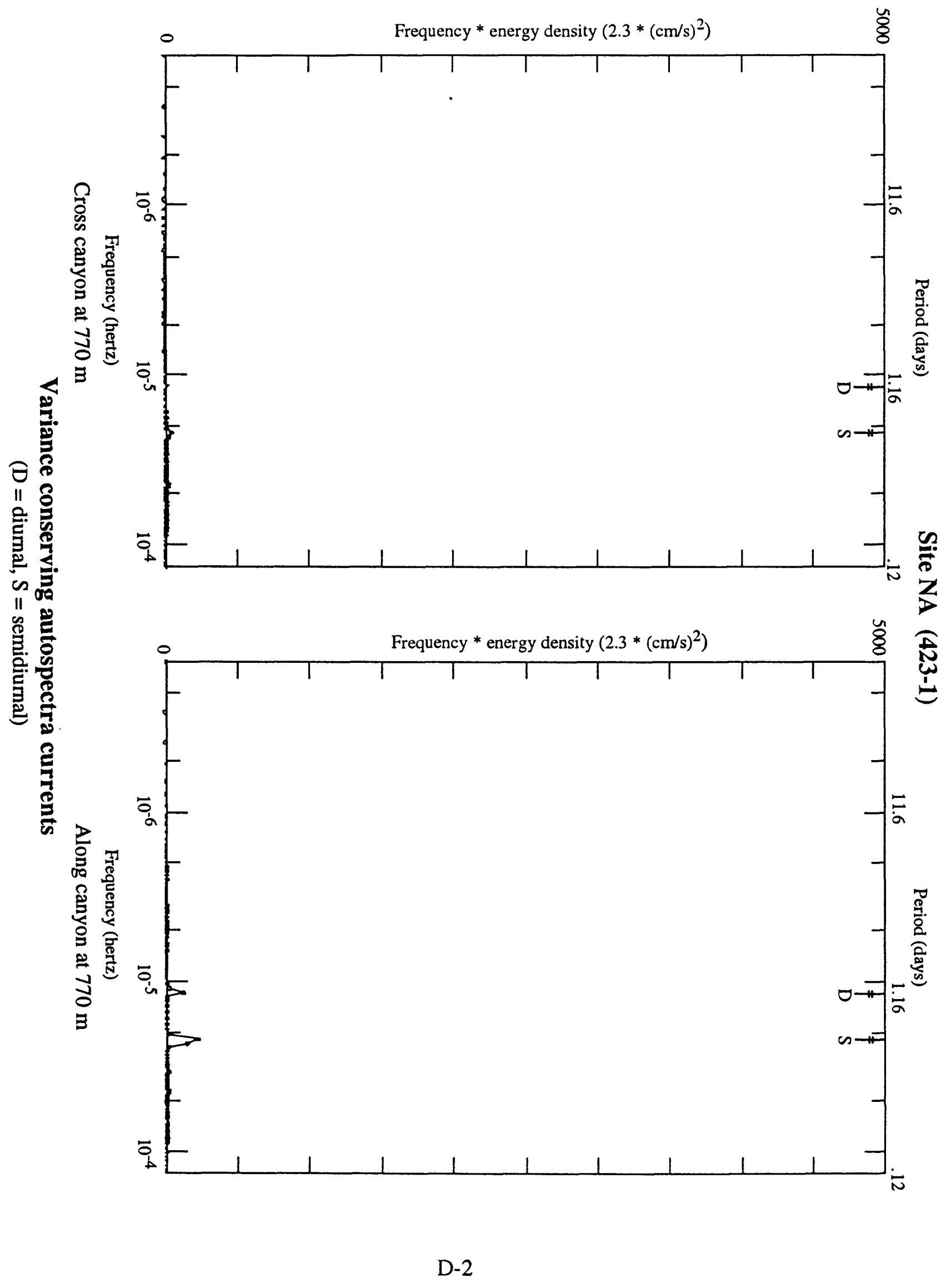




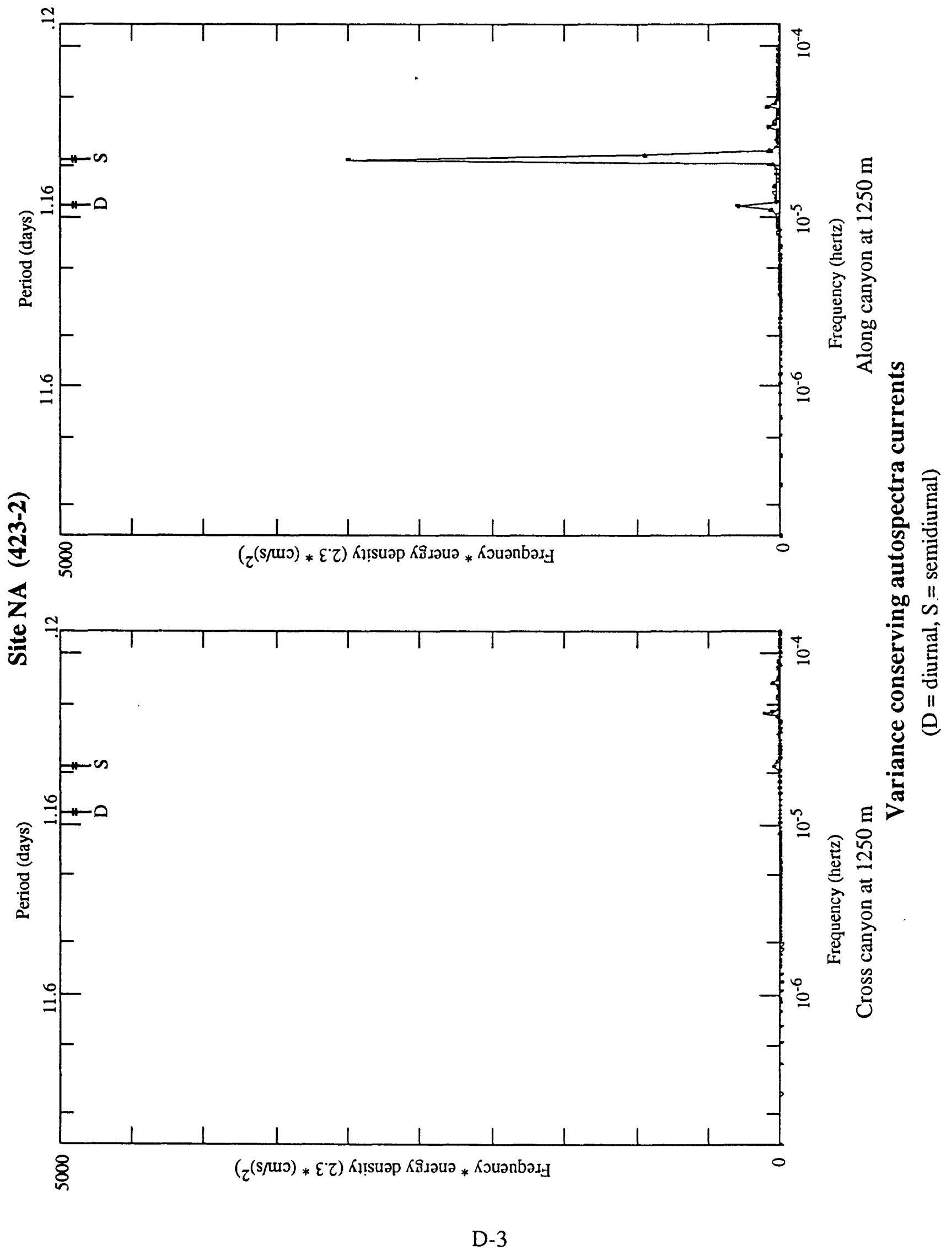




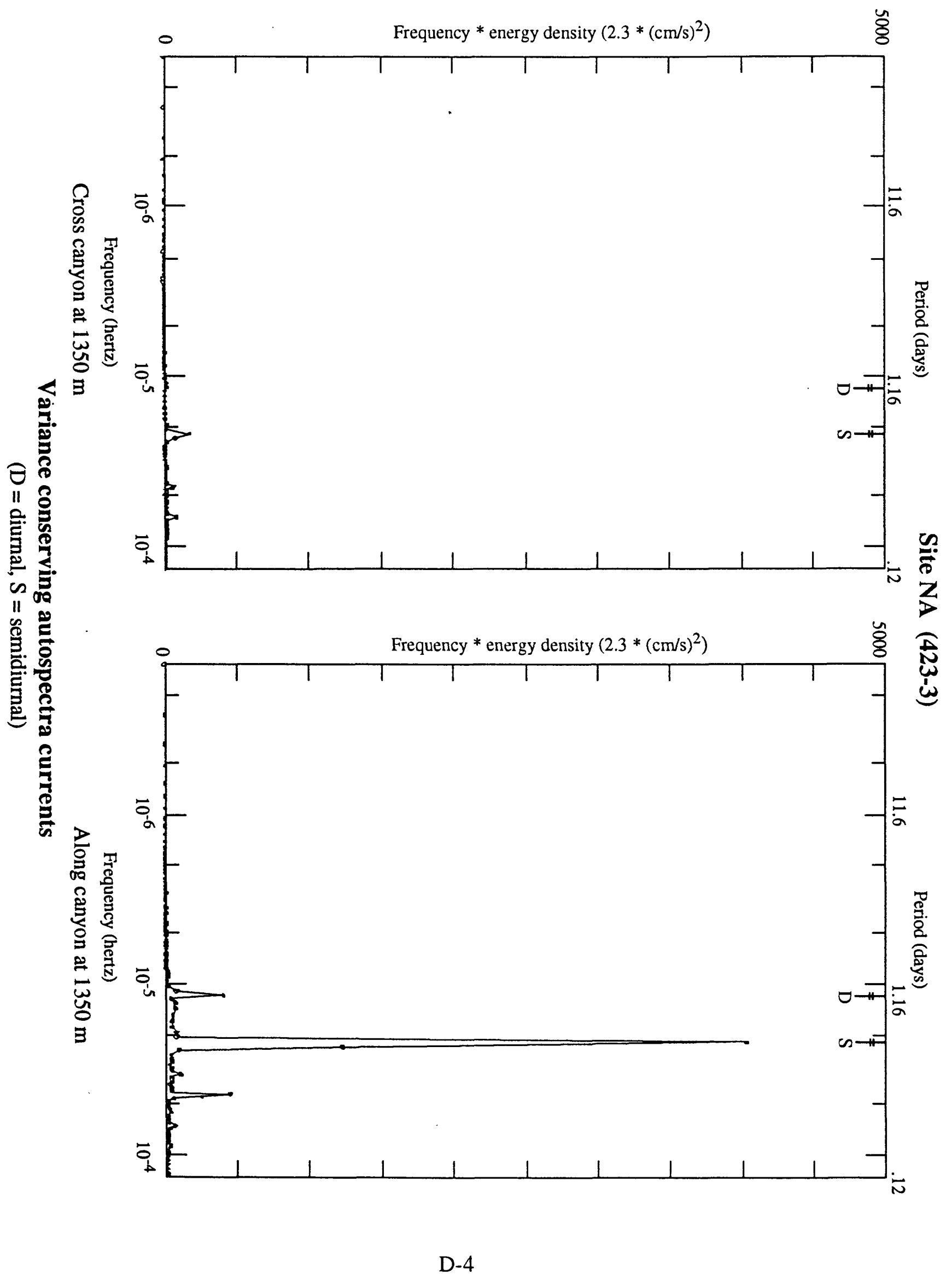




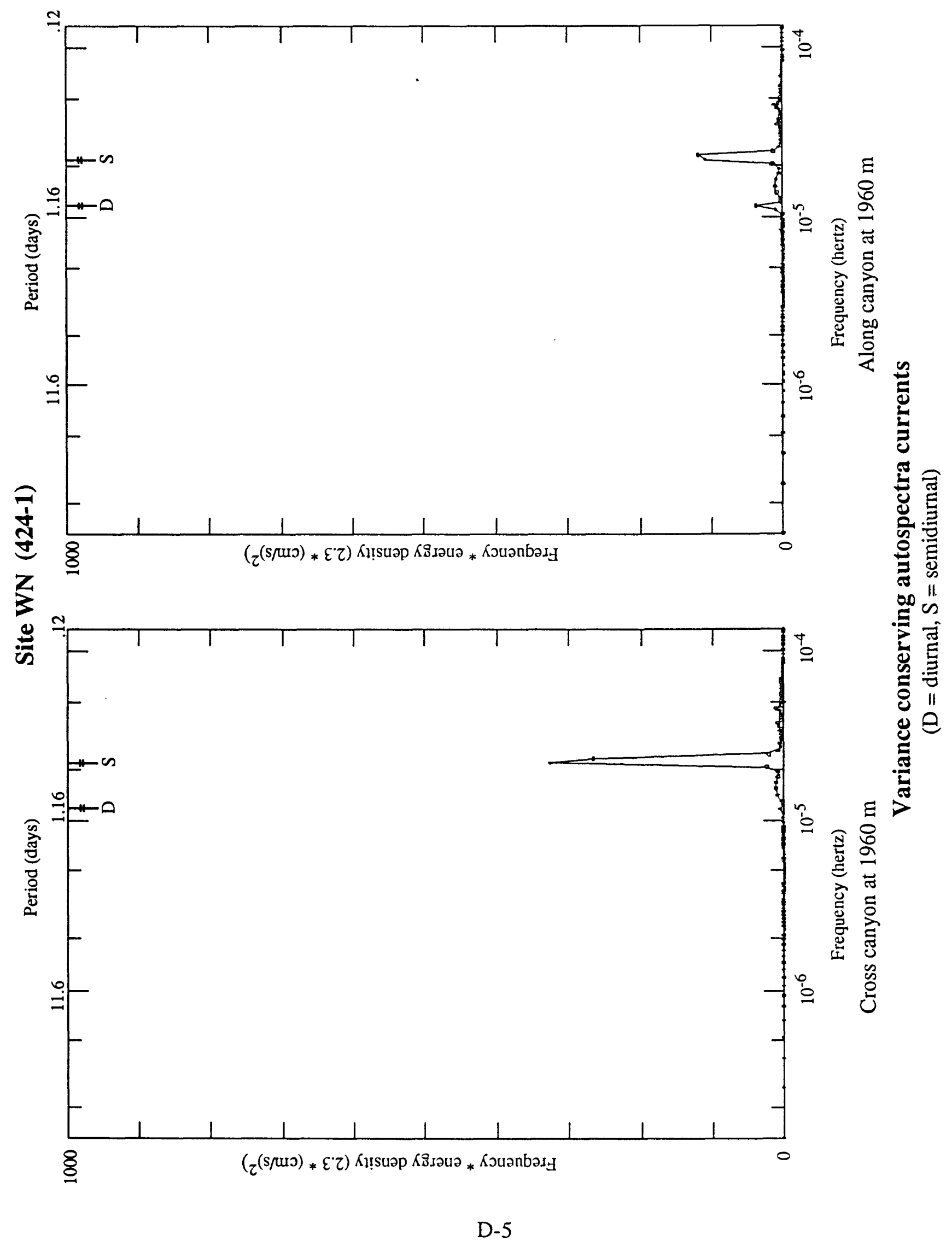




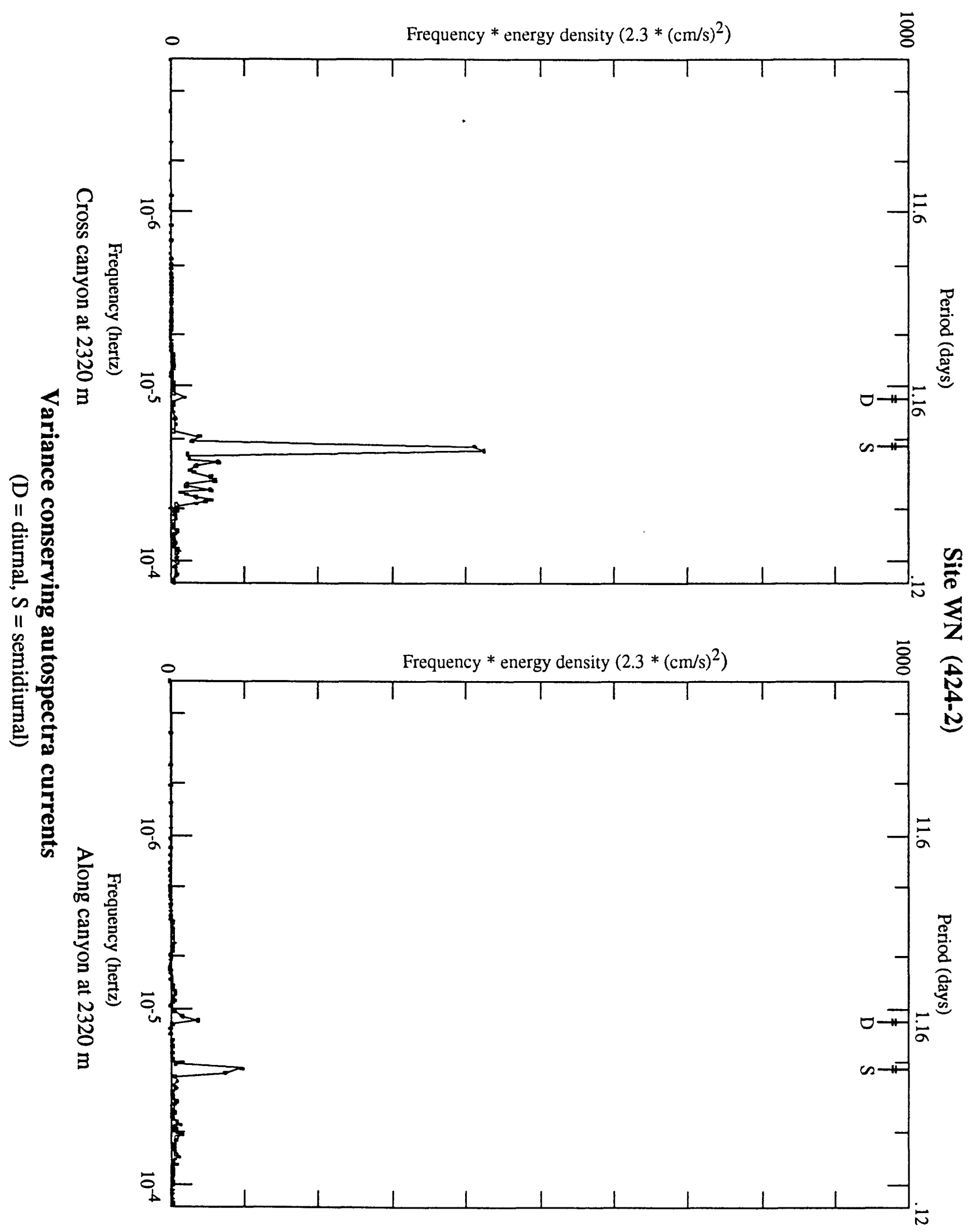

D-6 


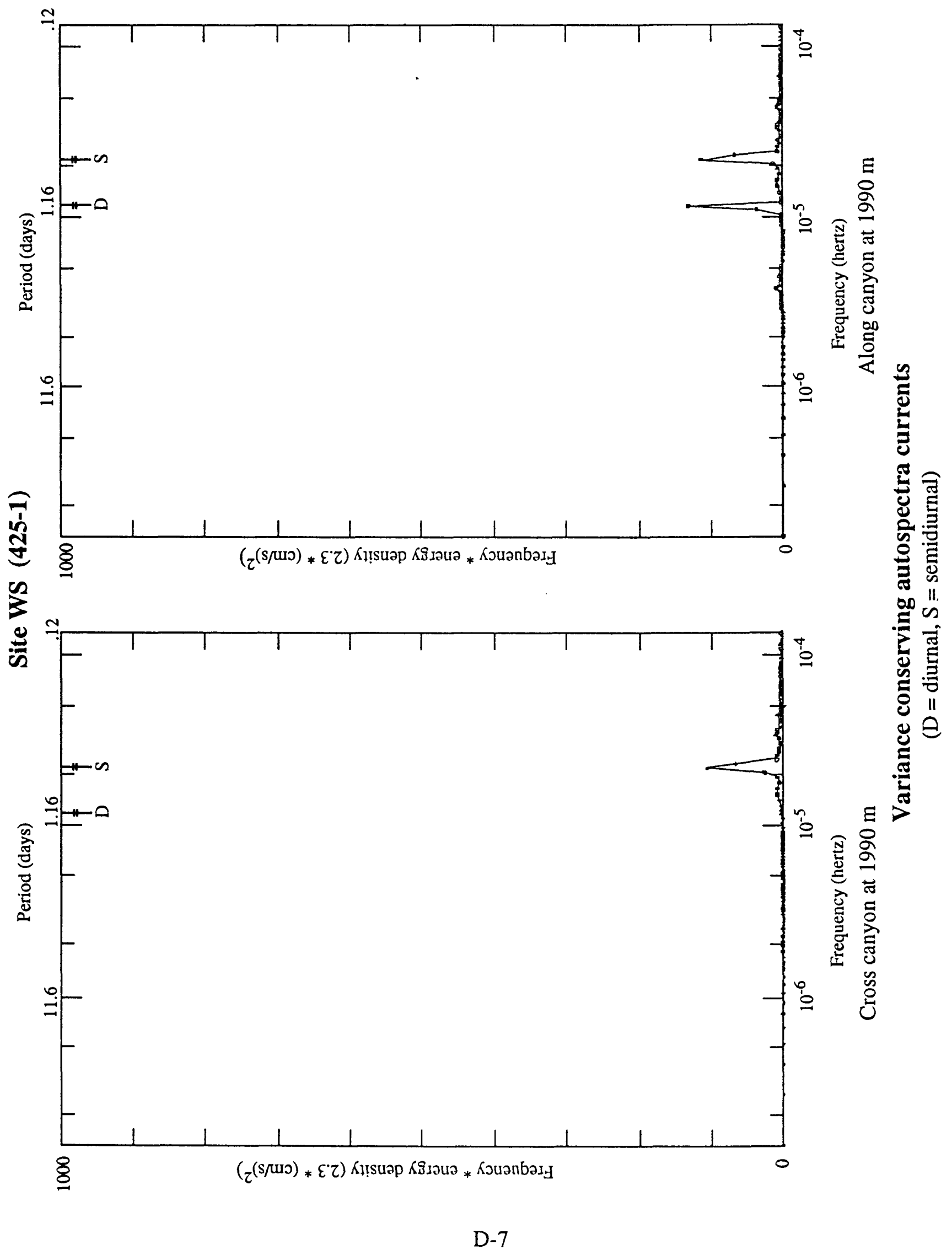




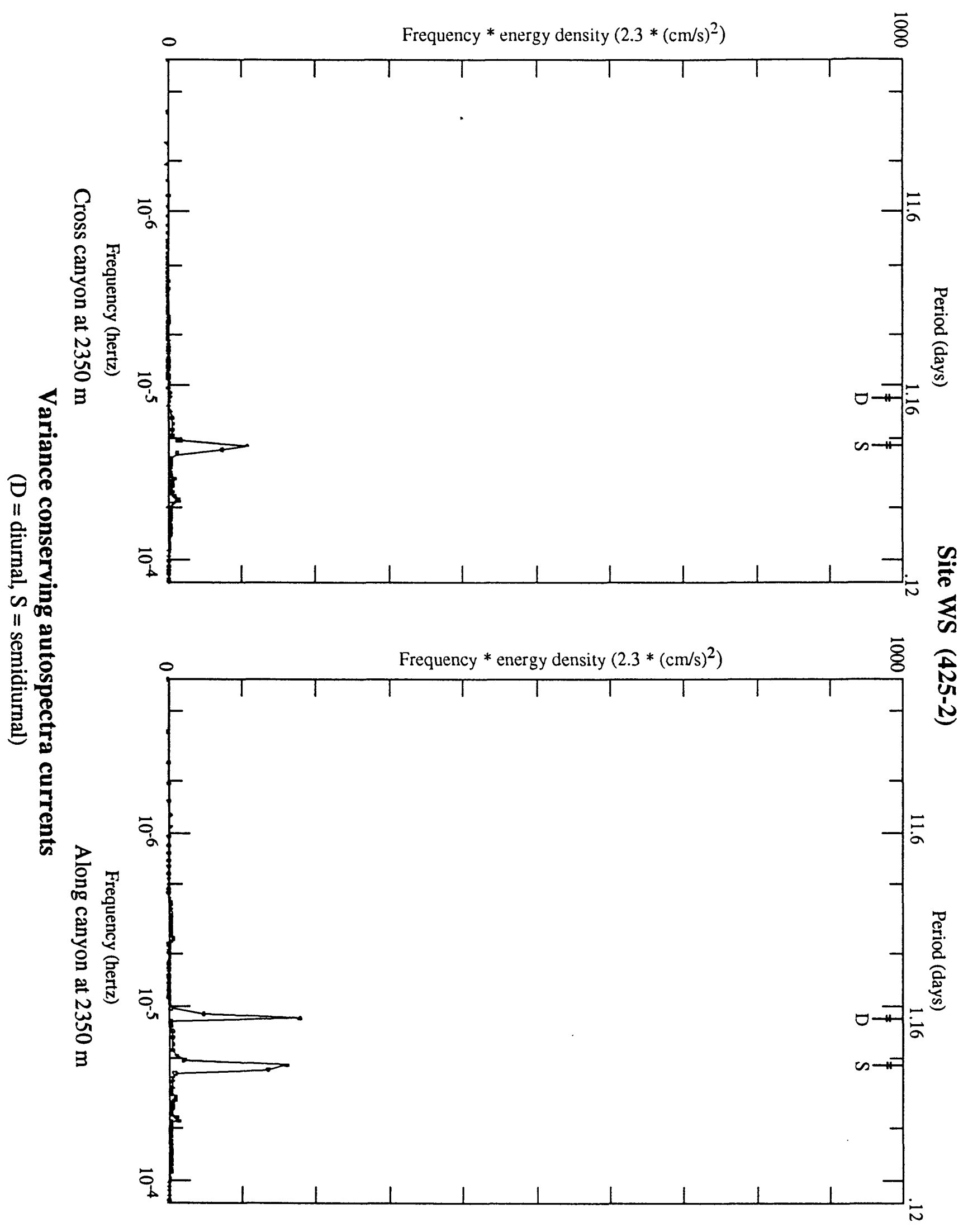

D-8 


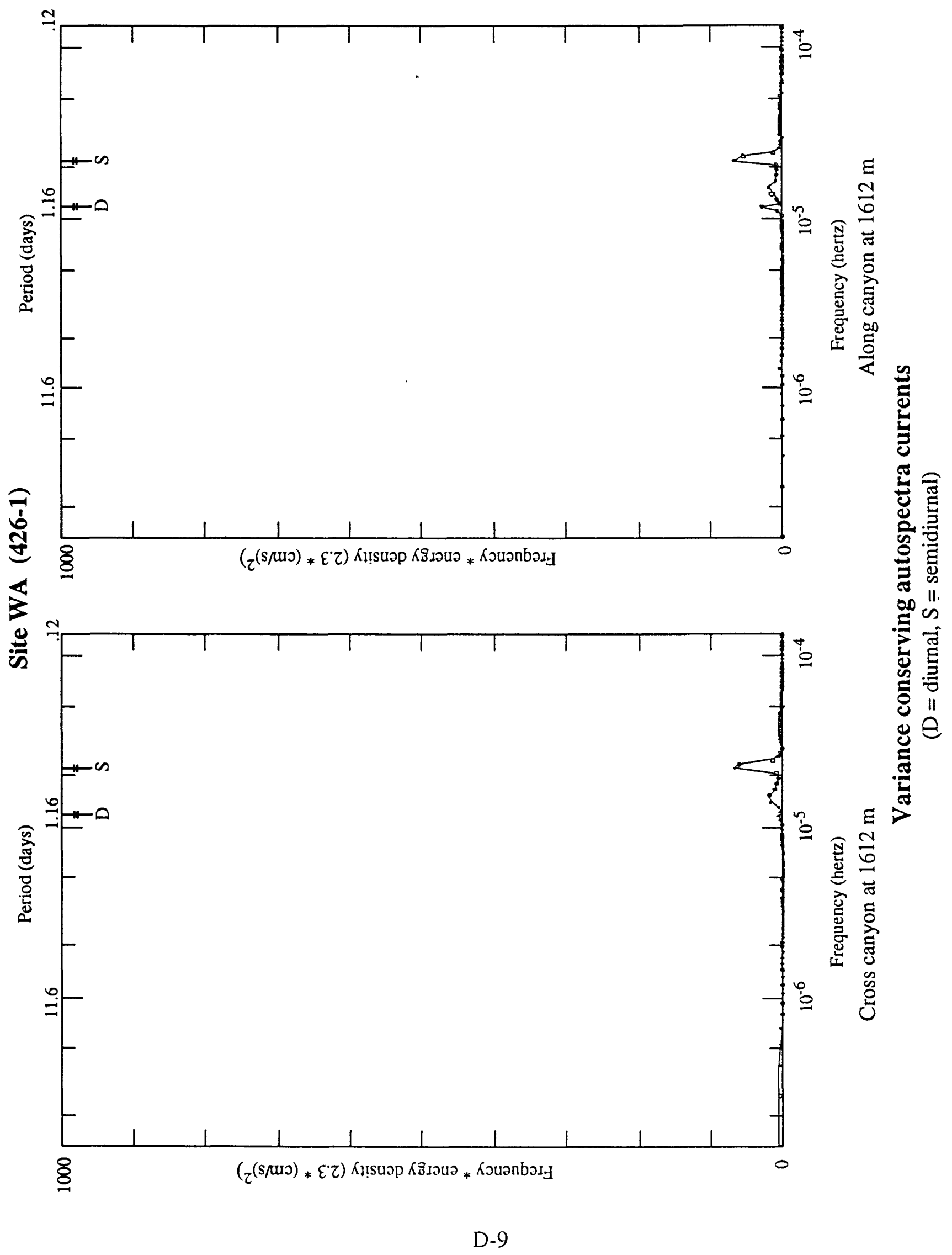




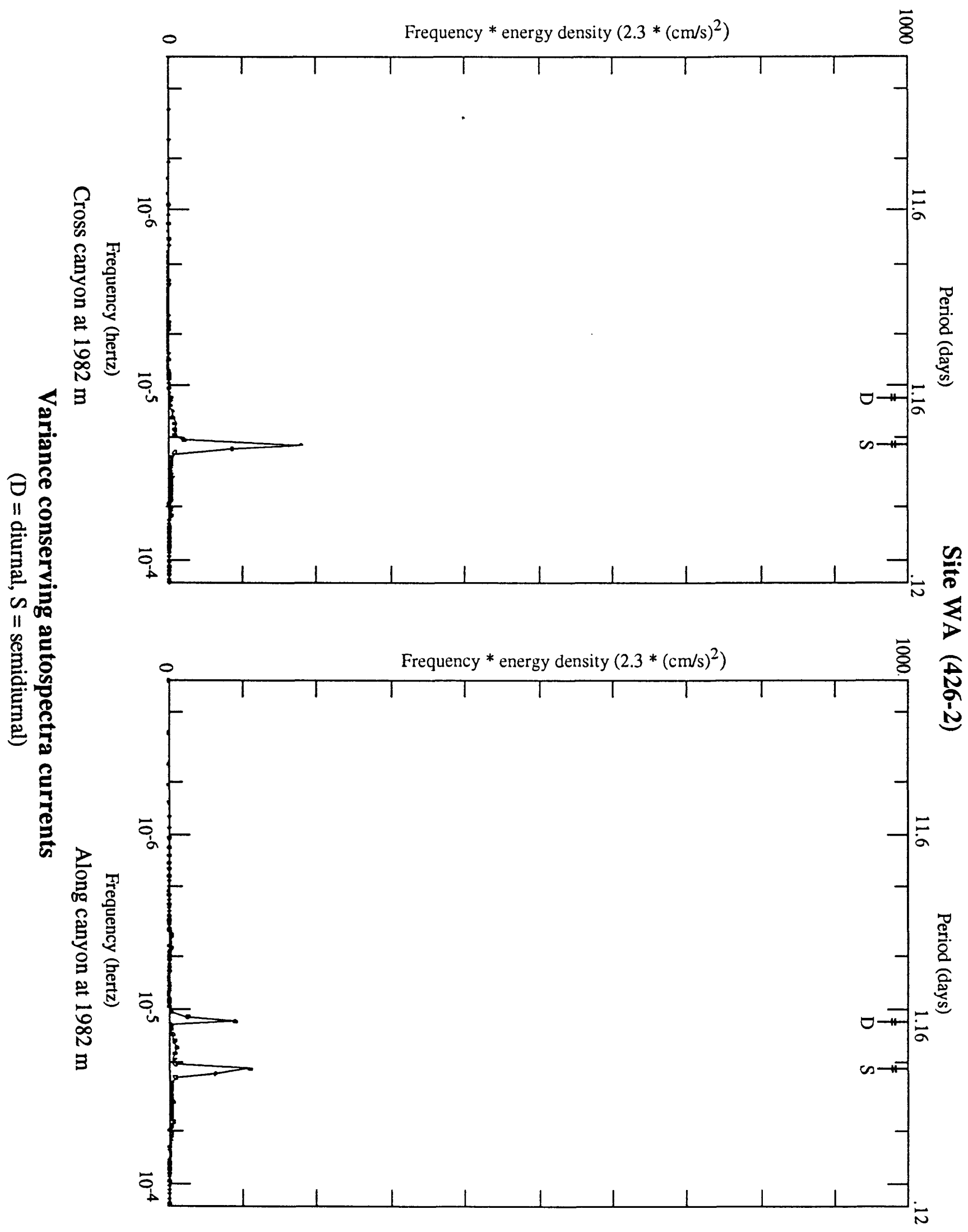

D-10 


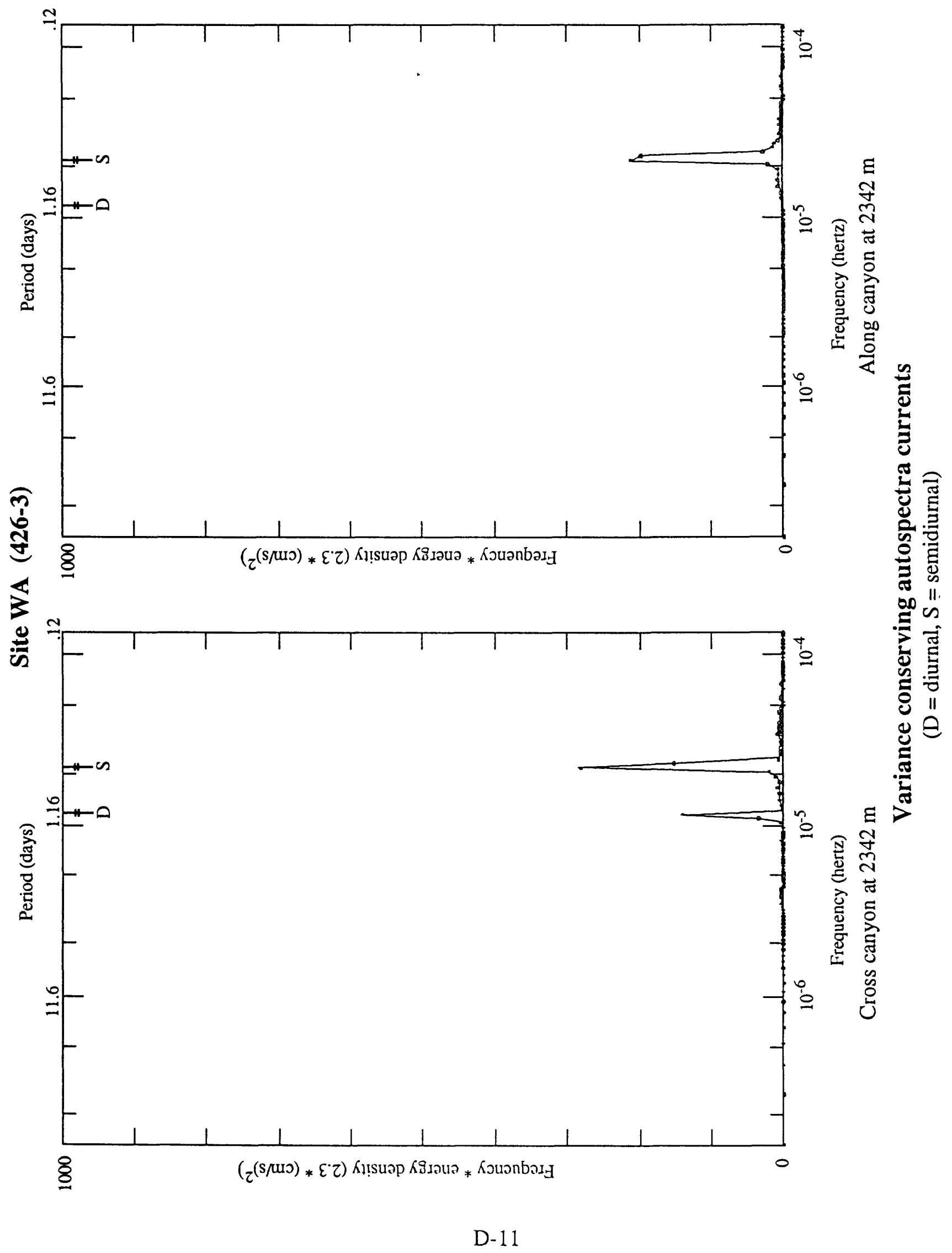




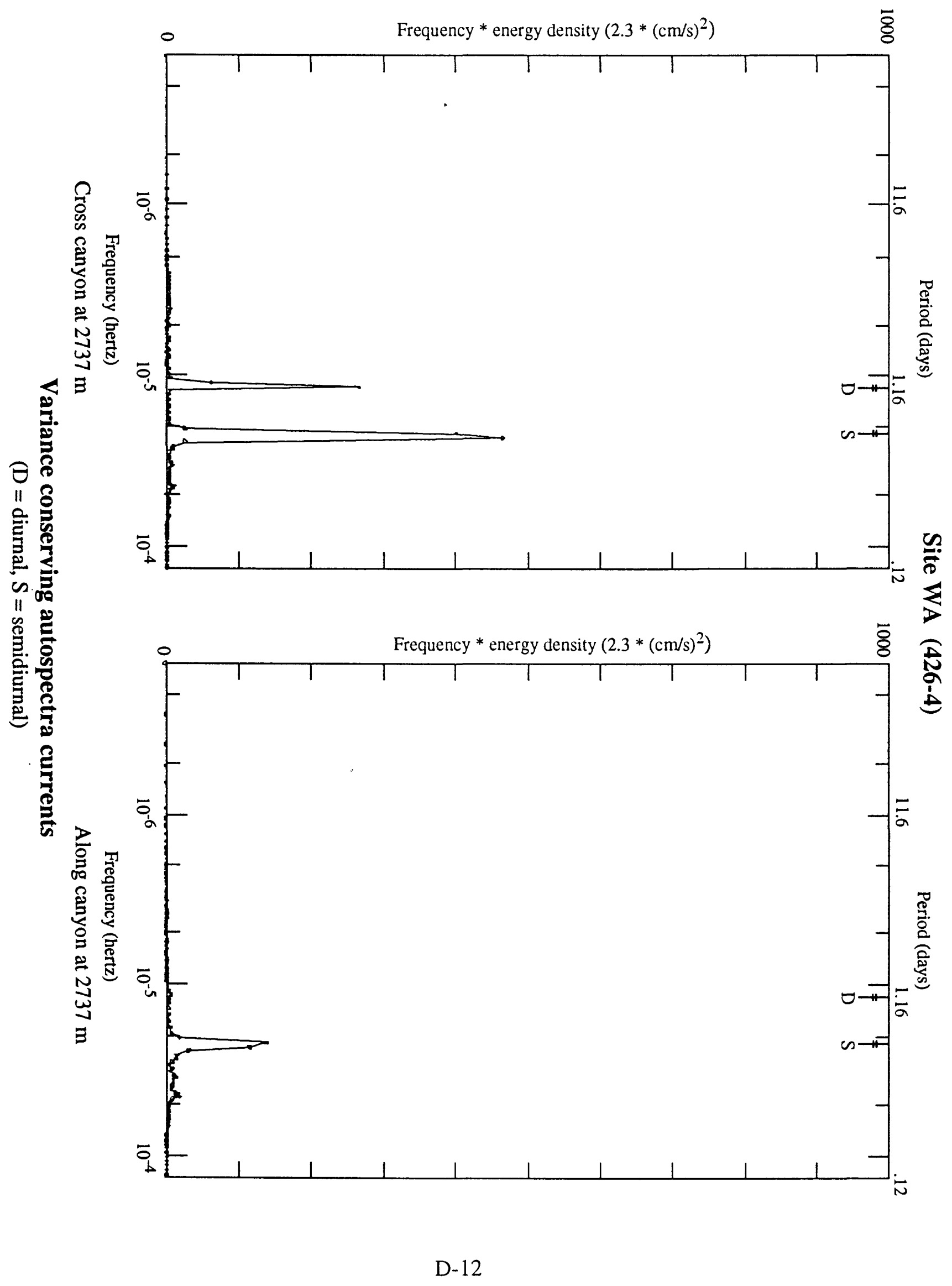




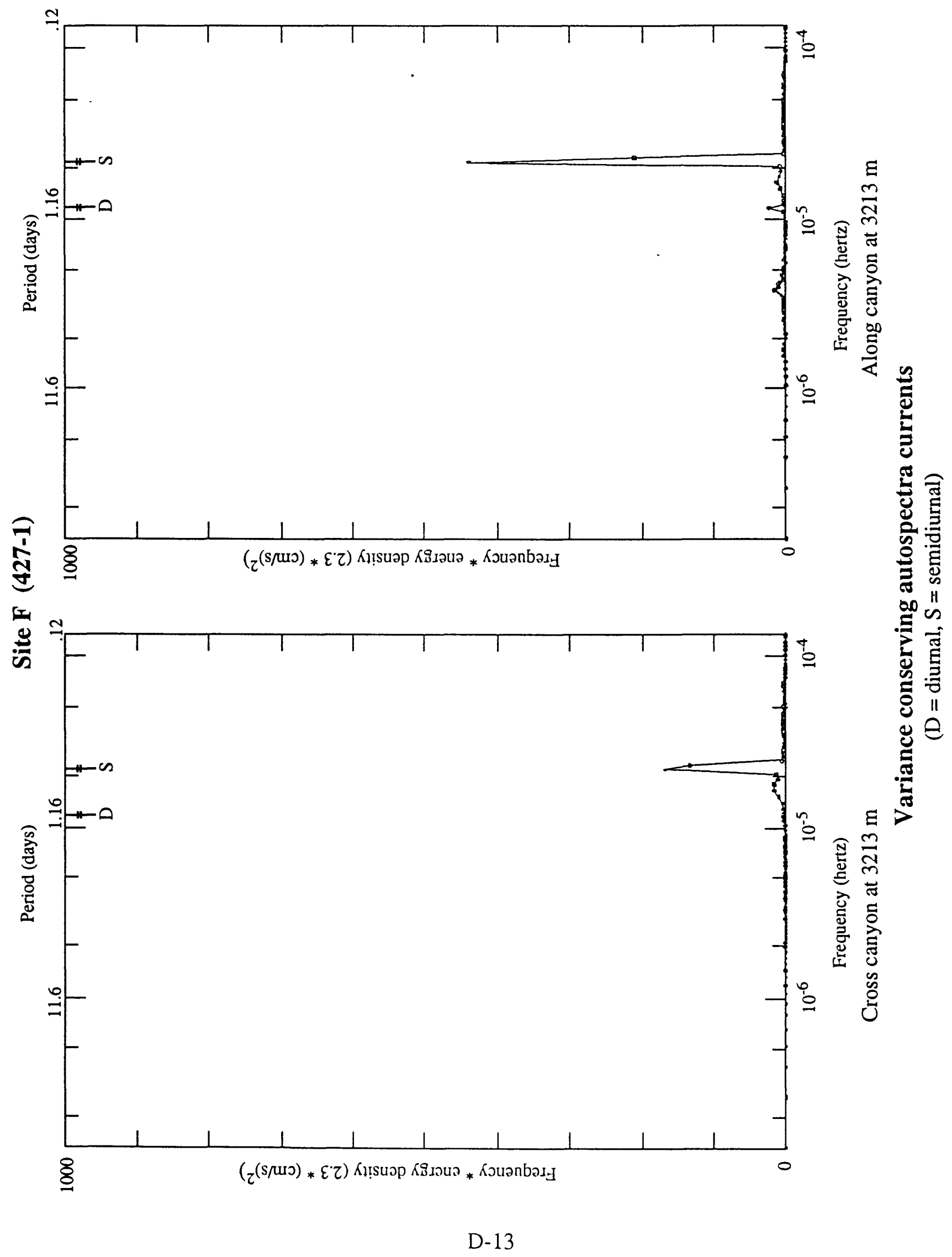




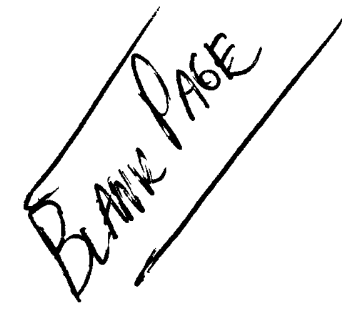




\section{Appendix E - Temperature, salinity and transmission}

Plots of hour-averaged temperature

E1 - E6

Plots of lowpassed temperature

E7 - E12

Plots of hour-averaged salinity

E13 - E16

Plots of lowpassed salinity

E17 - E20

Plots of hour-averaged transmission

E21 - E24 


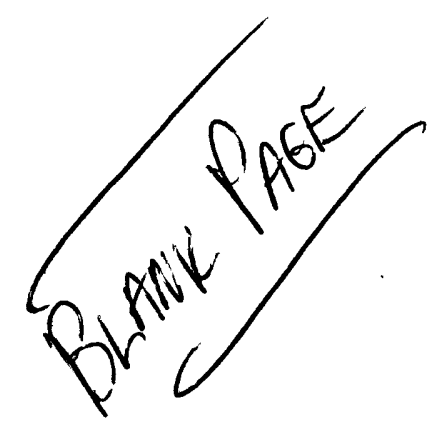




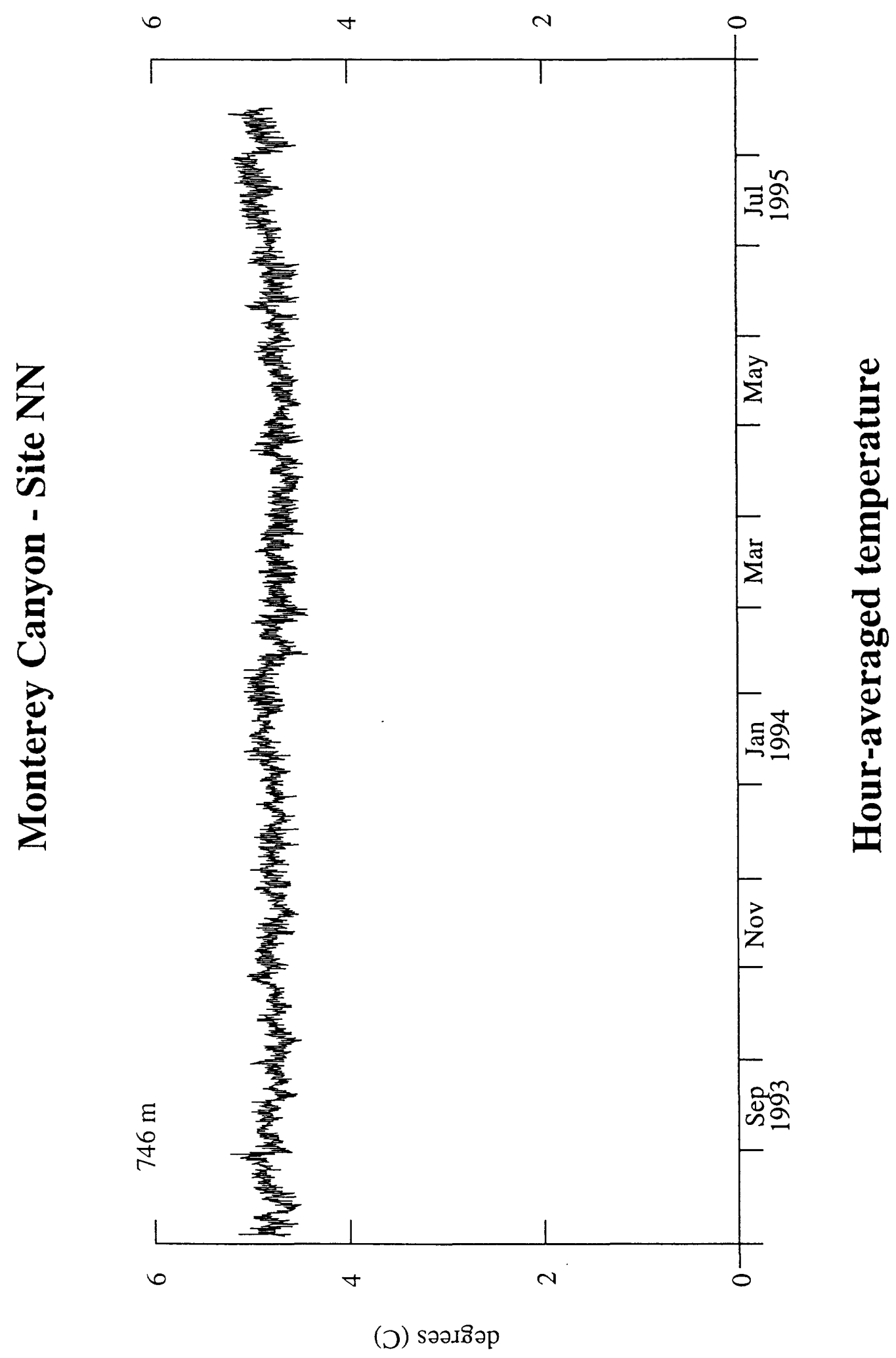

E-1 


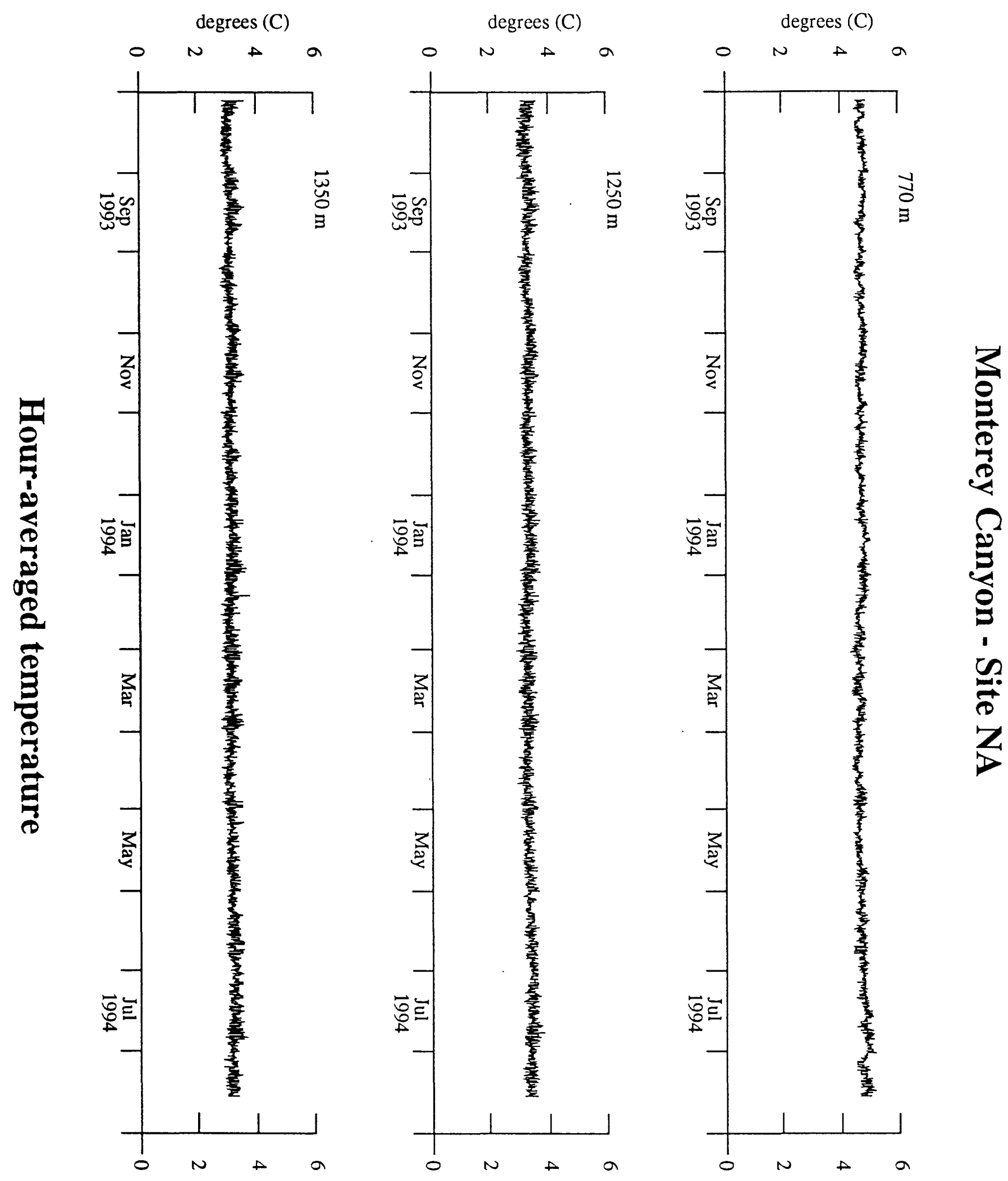

E-2 

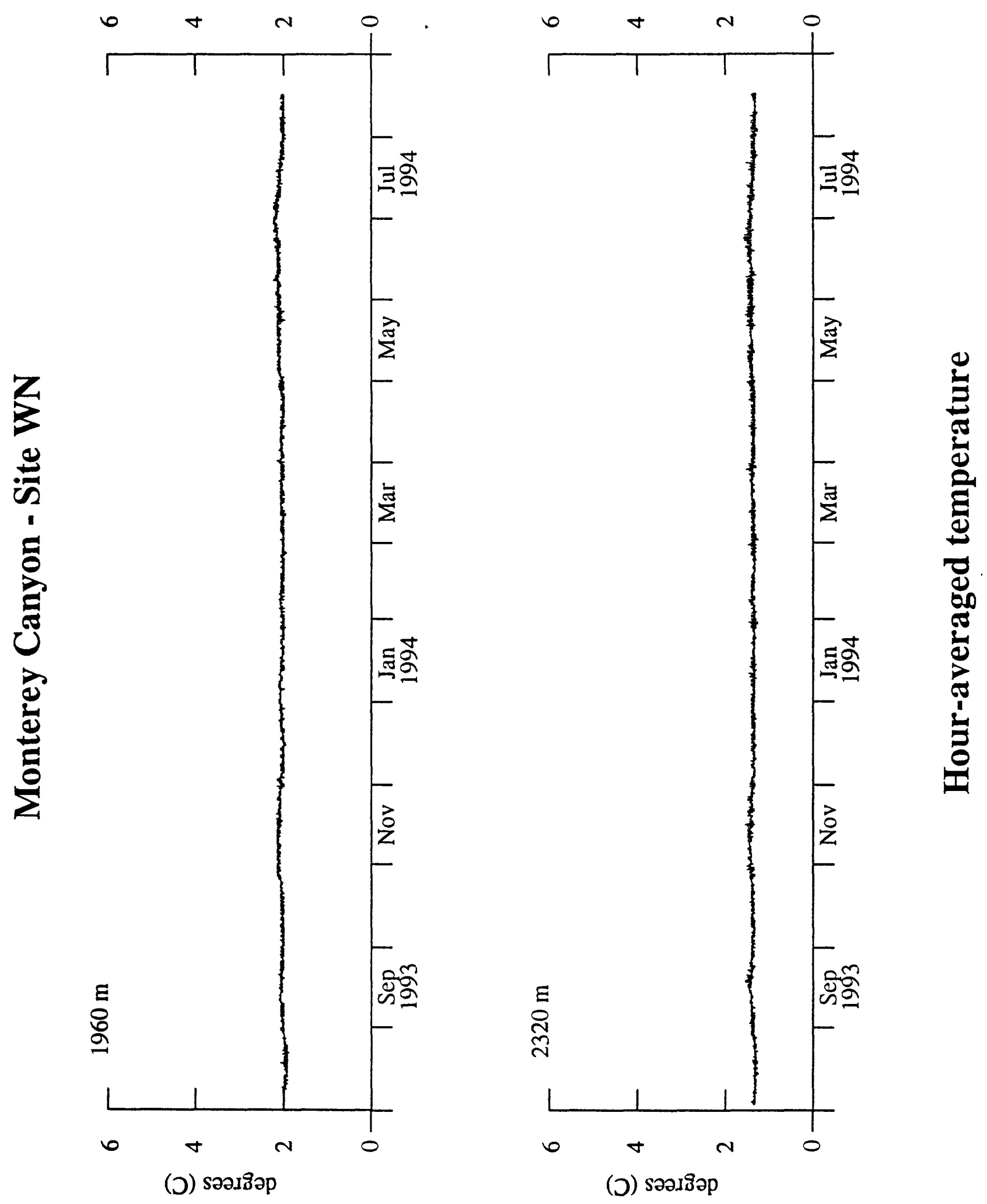

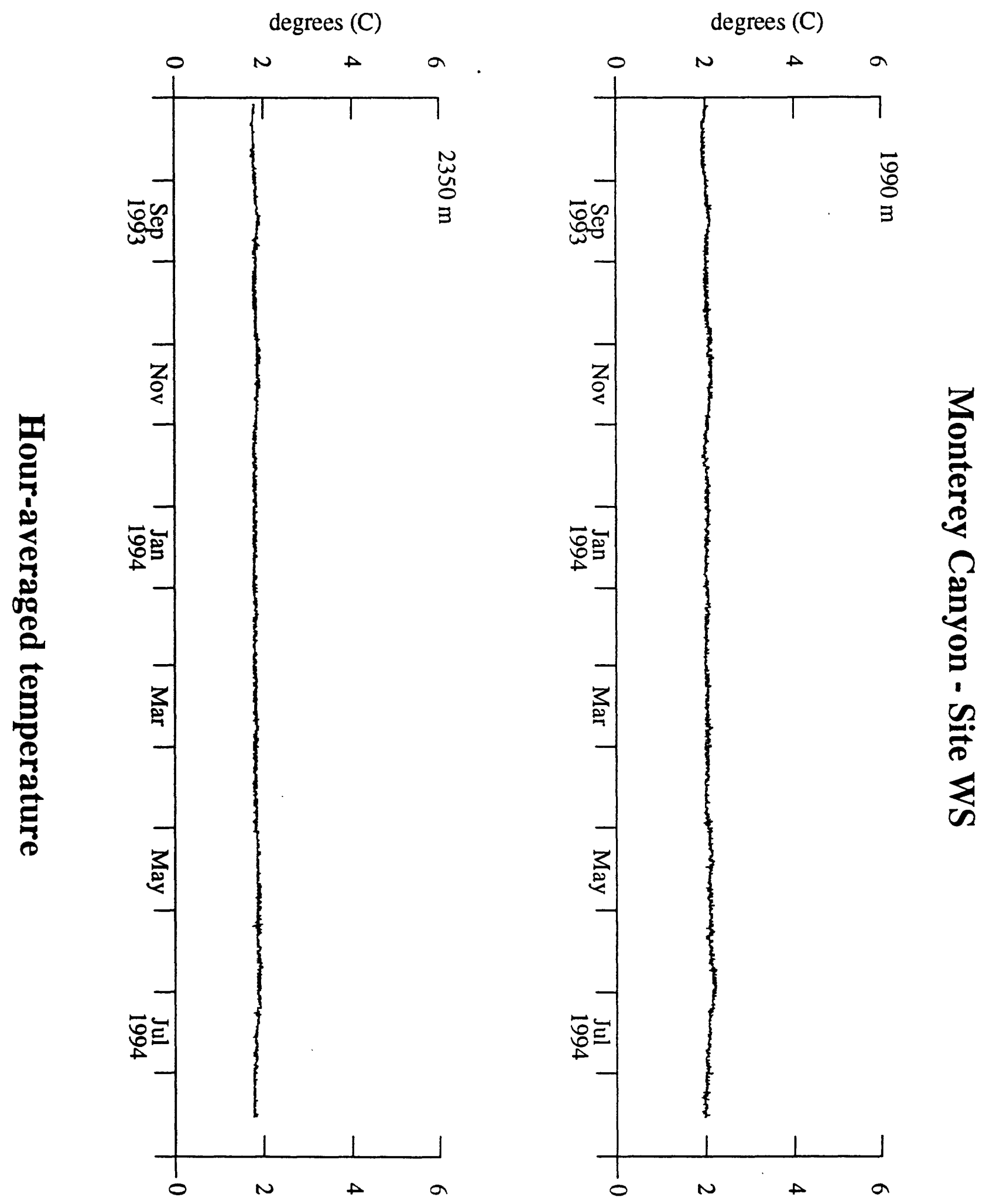


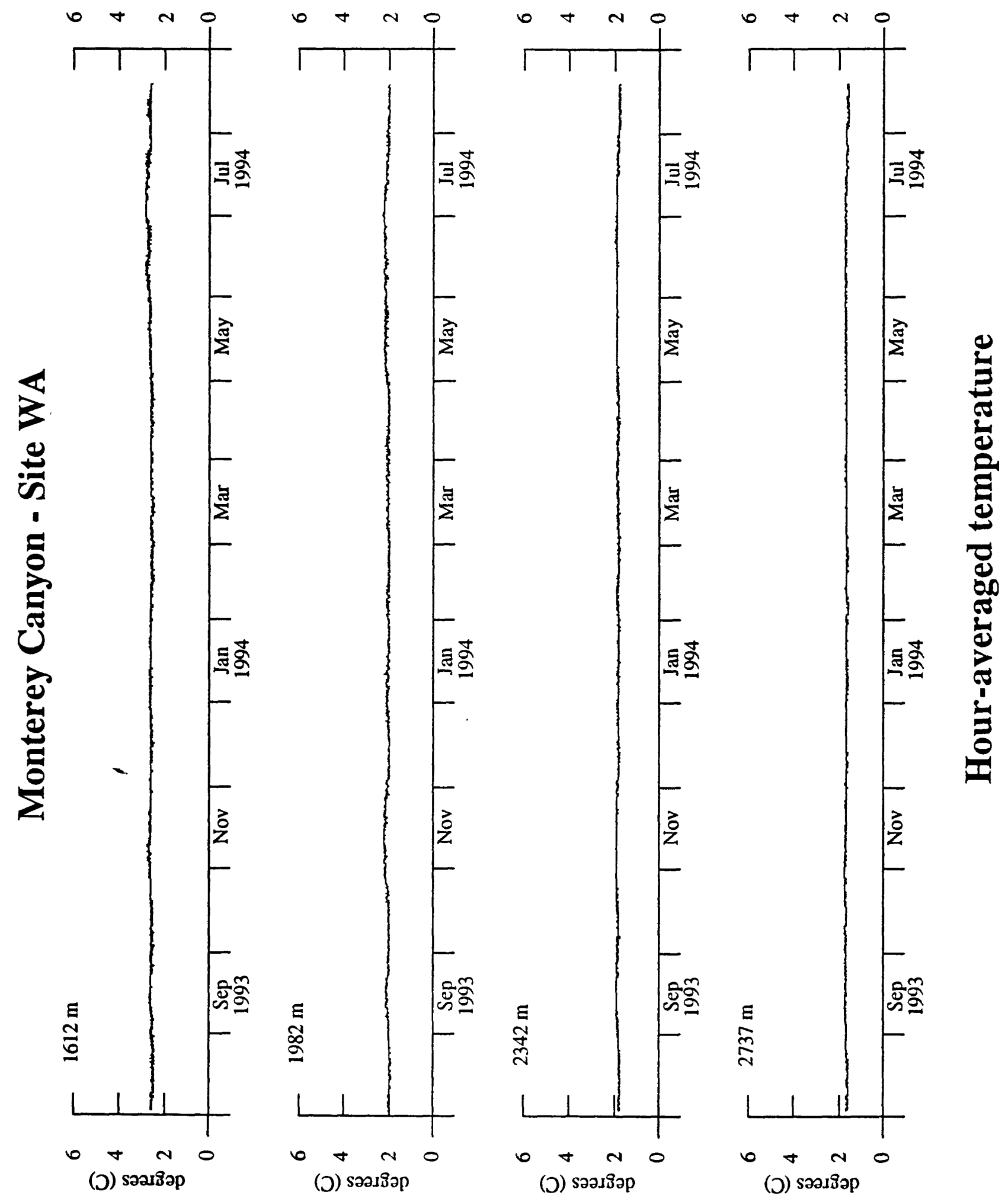

E-5 


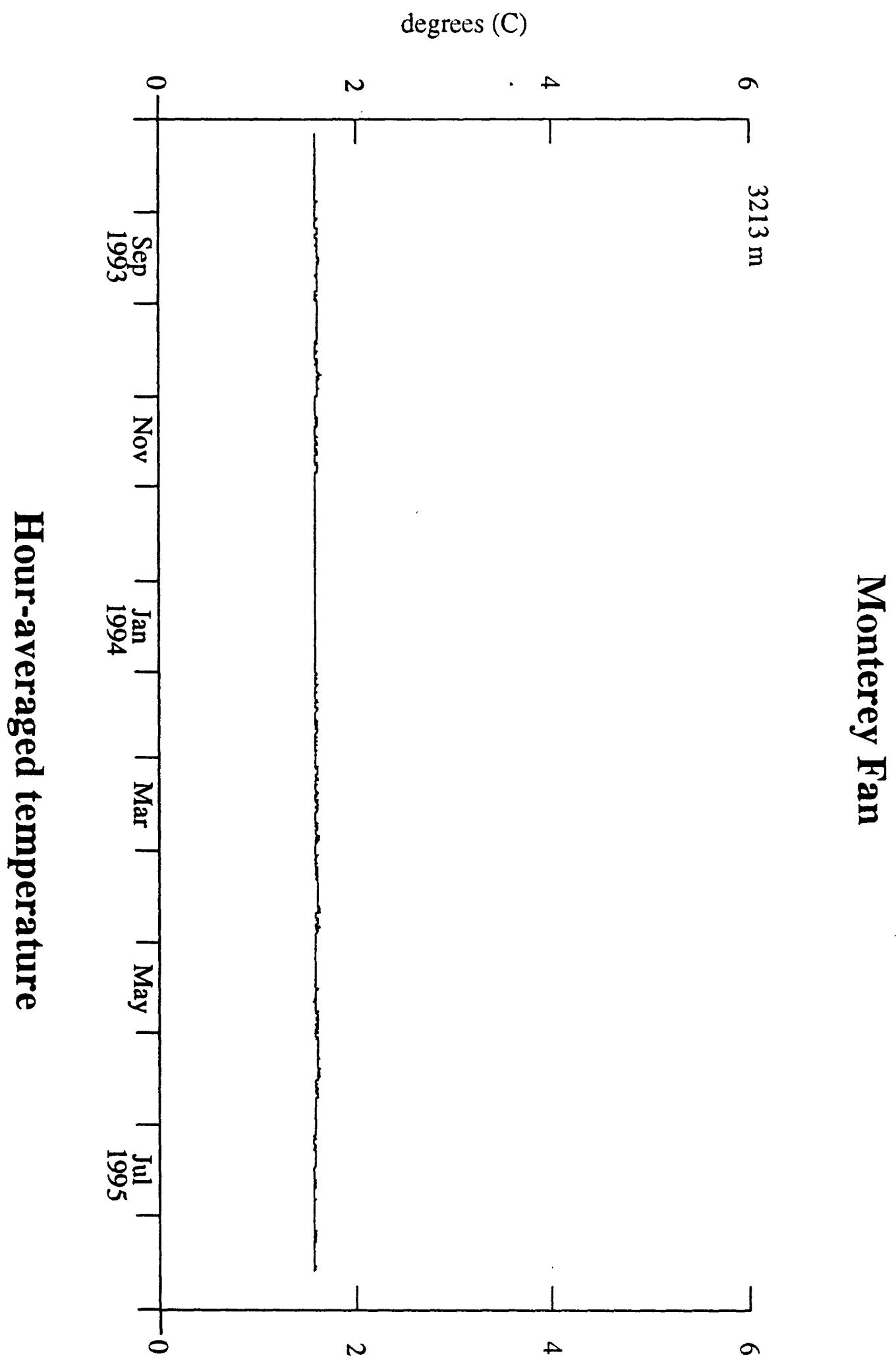




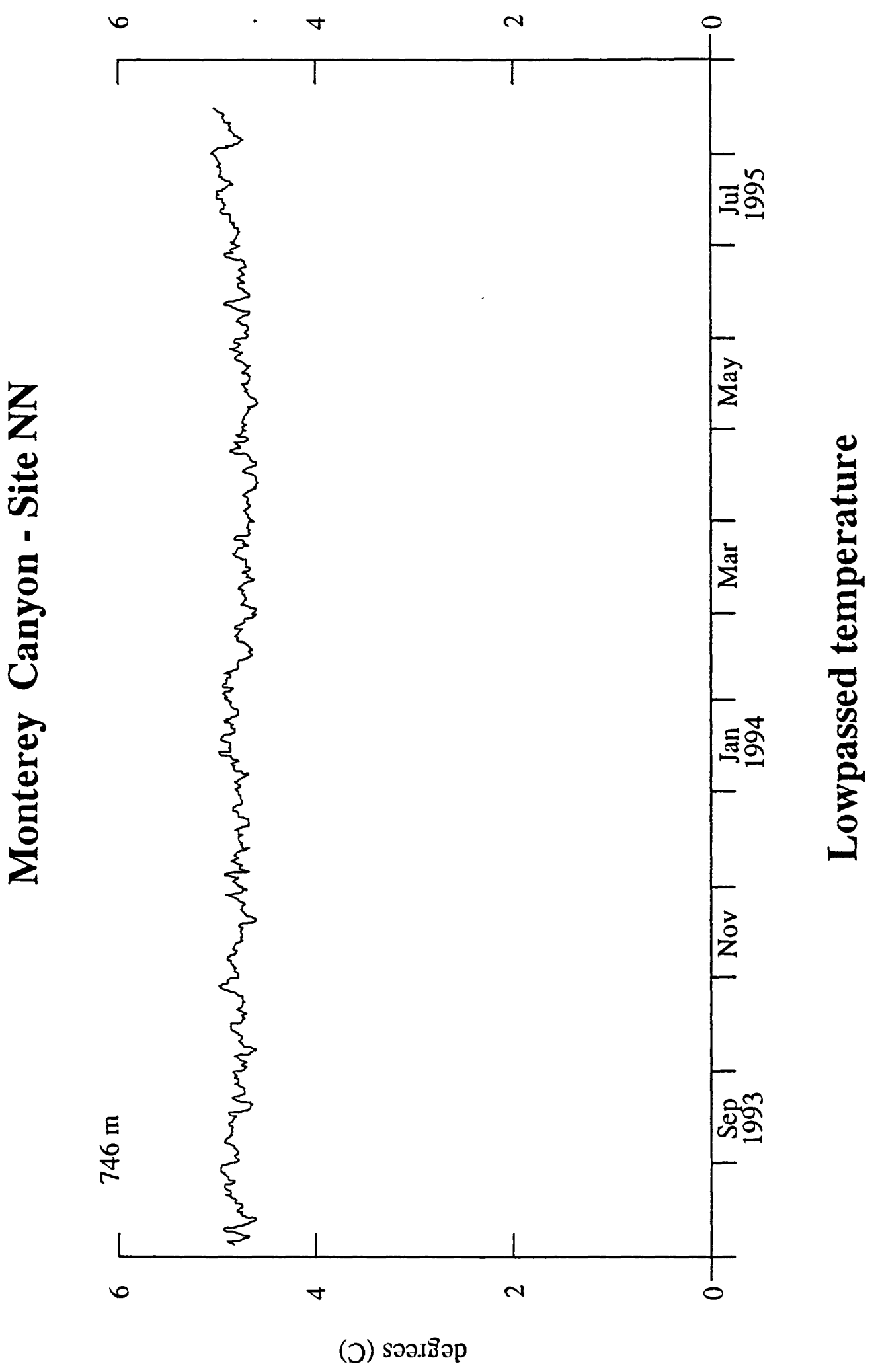

E-7 


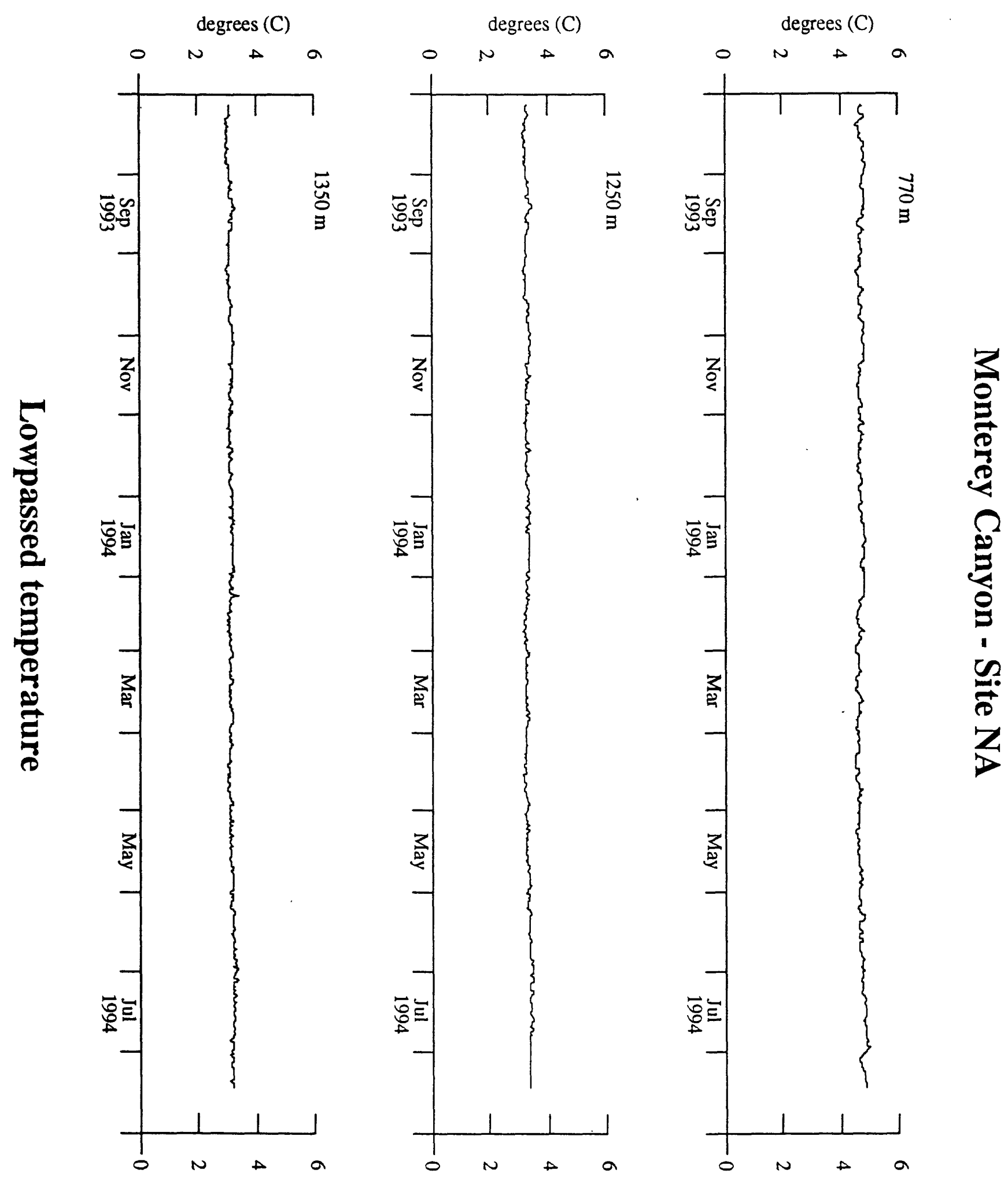




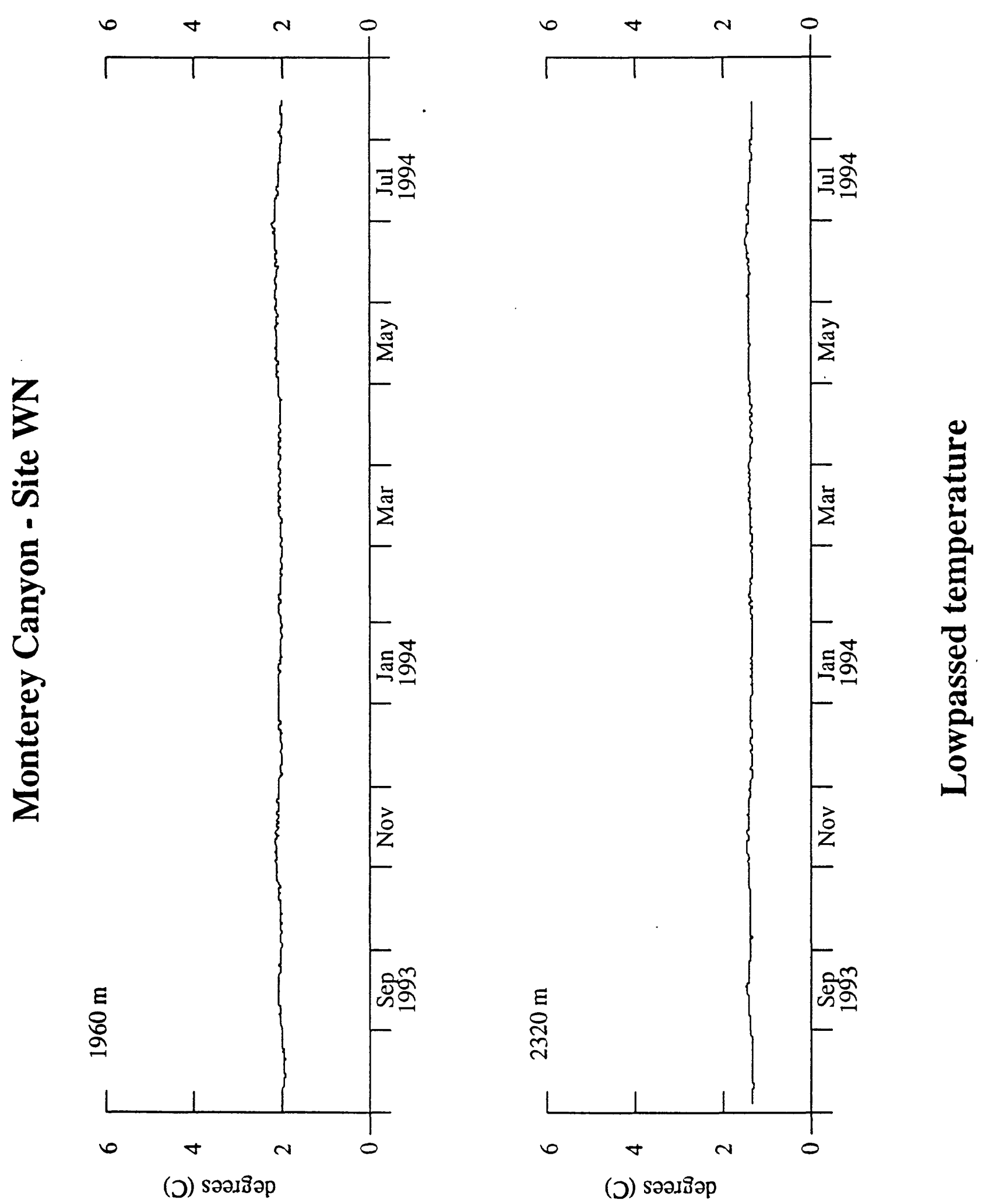



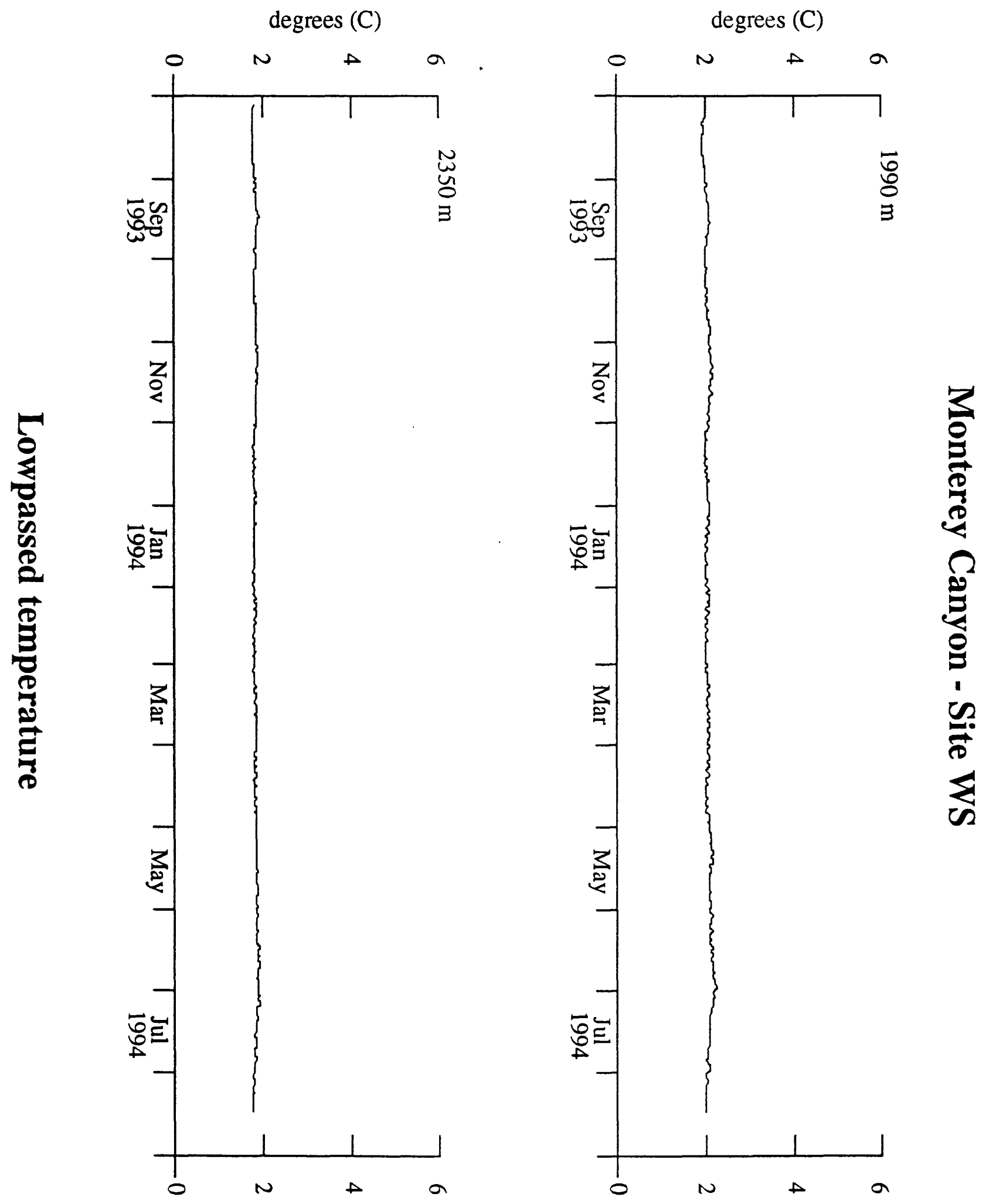

E-10 


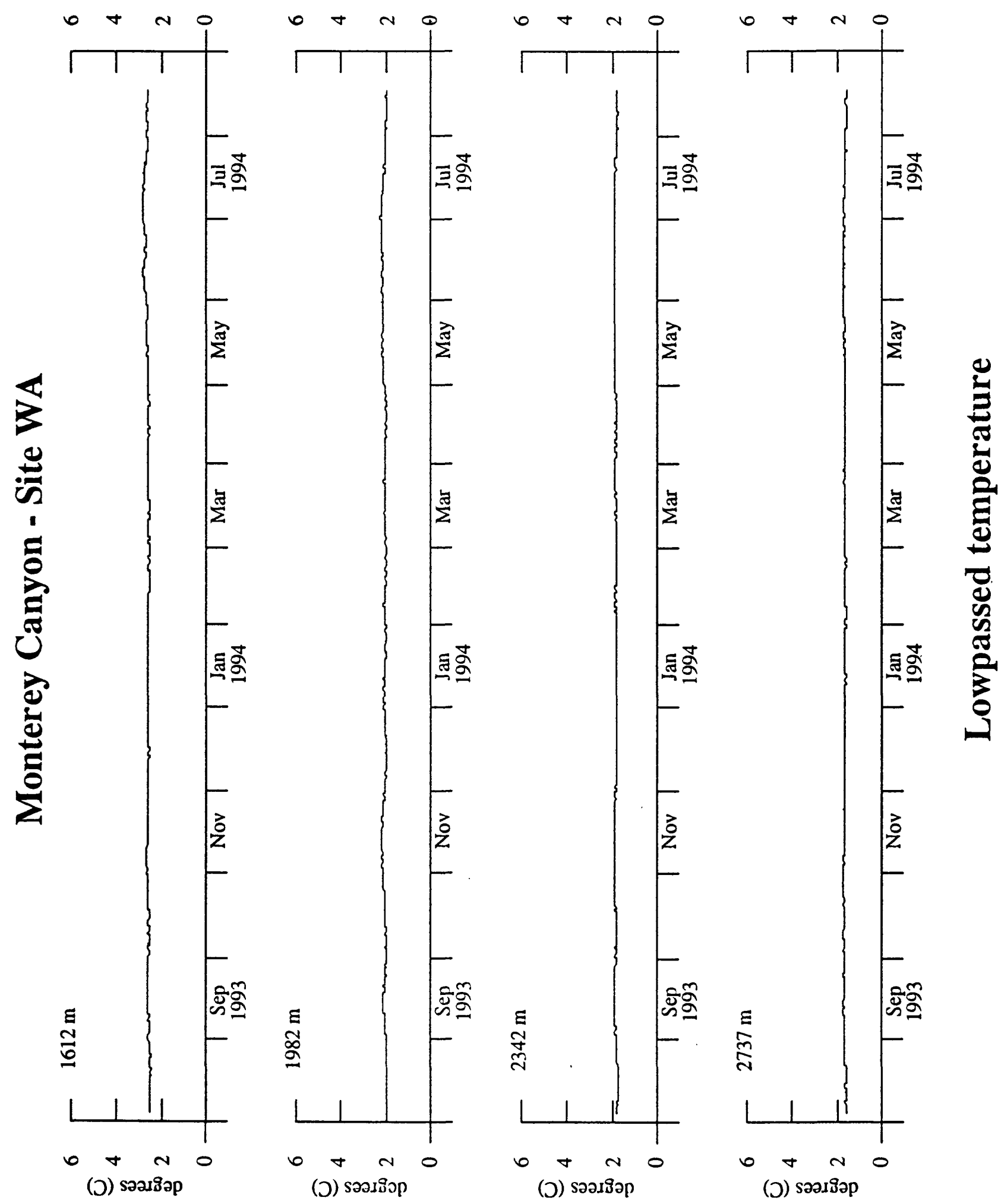

E-11 
degrees (C)

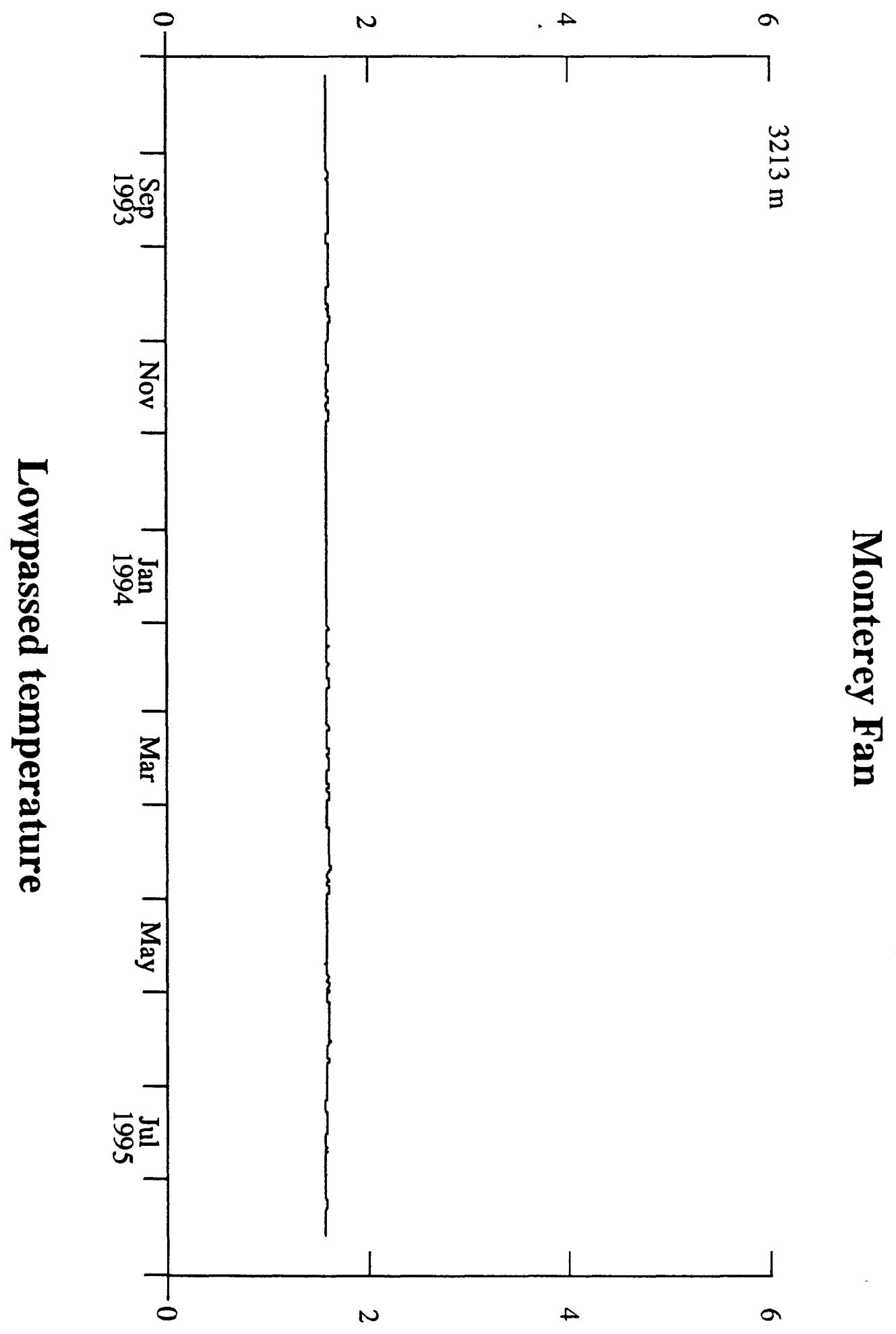




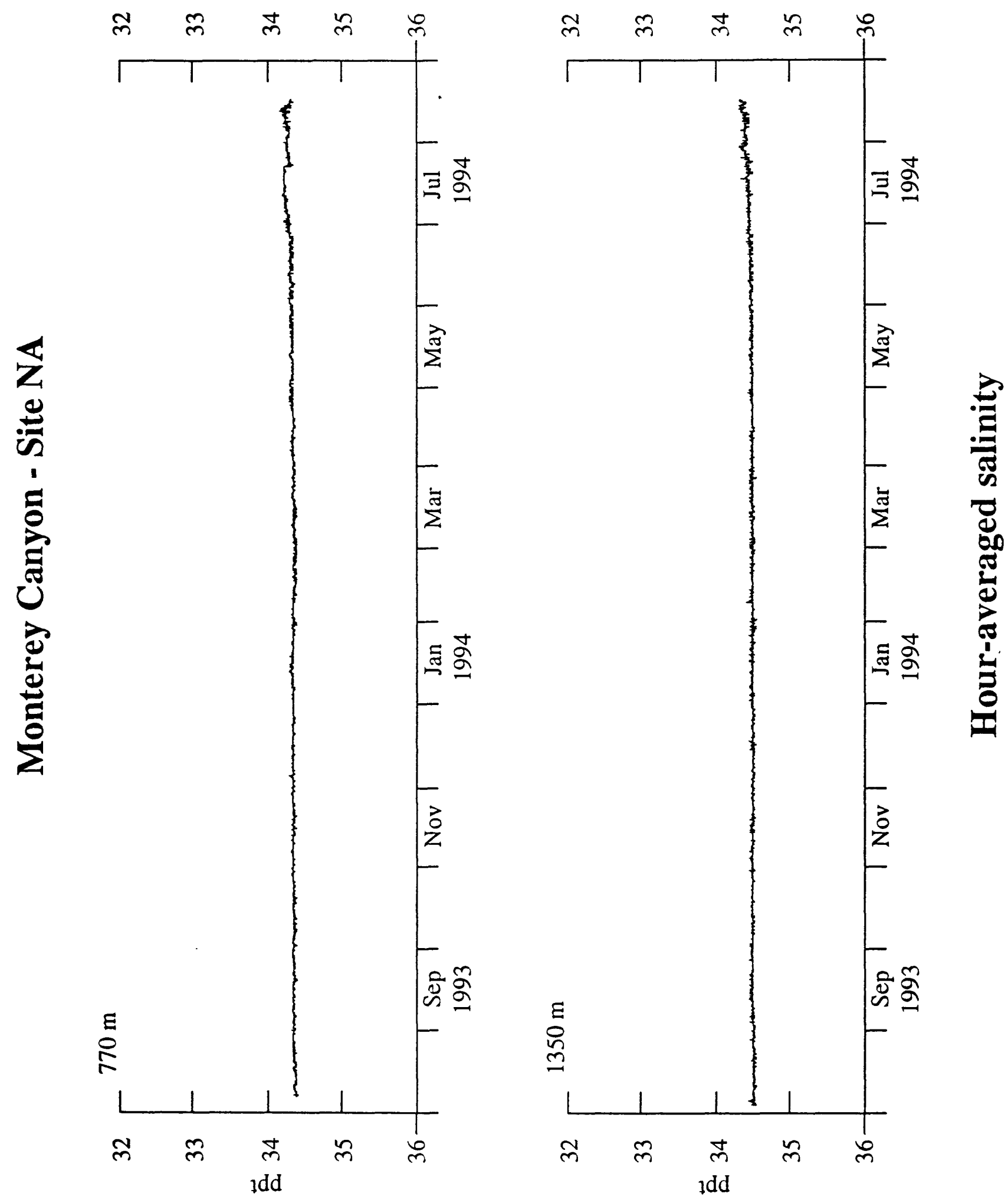



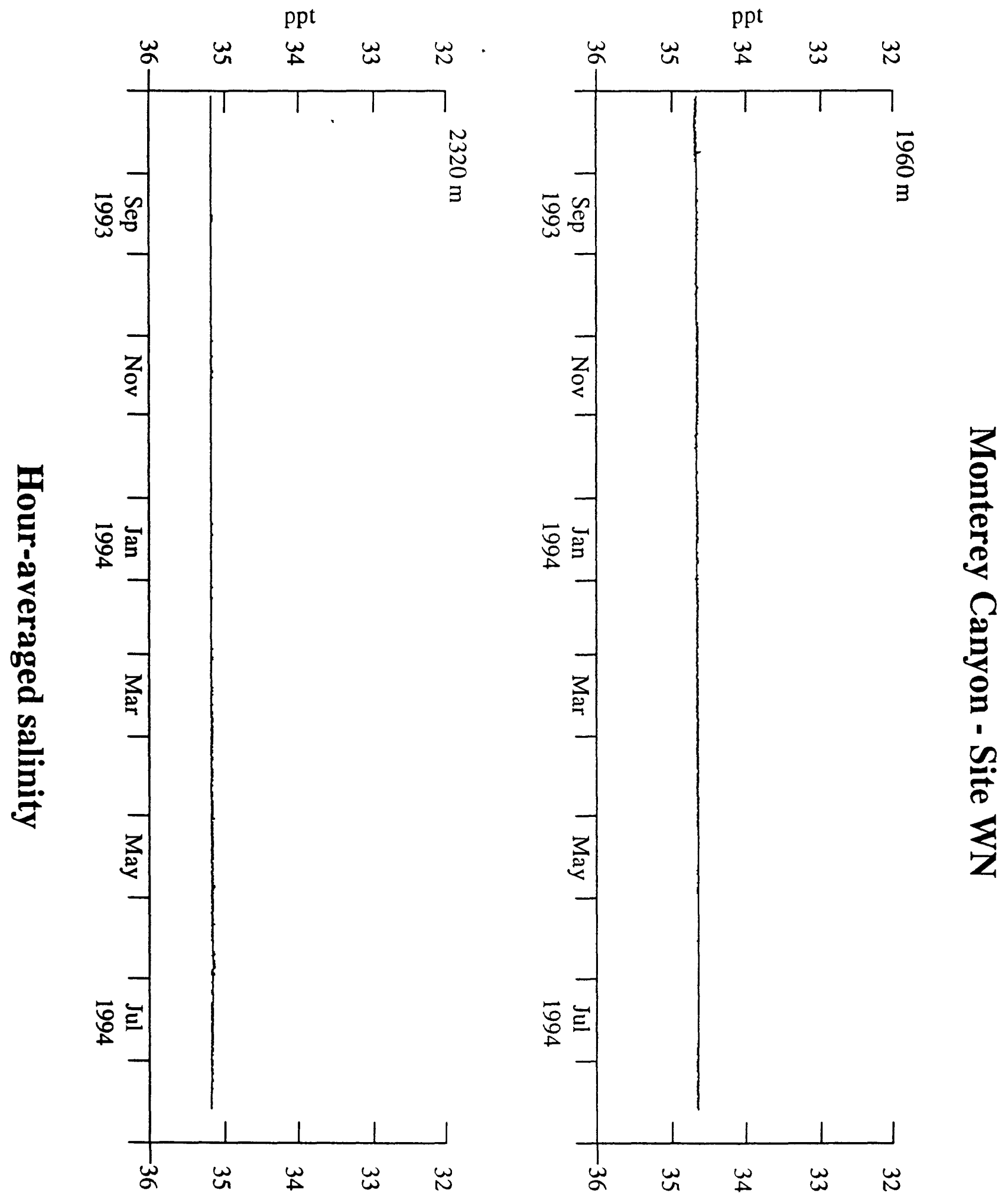

E-14 


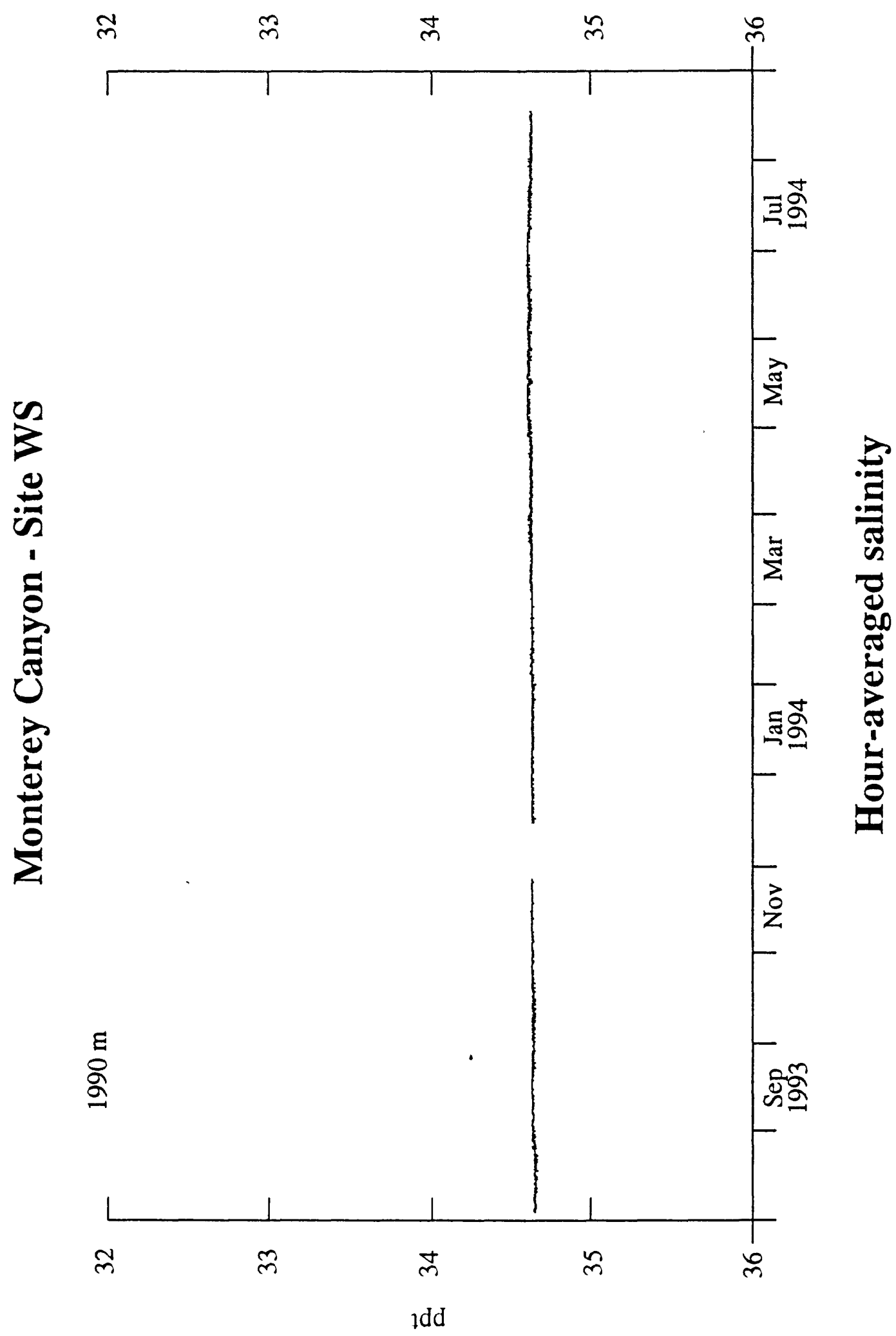




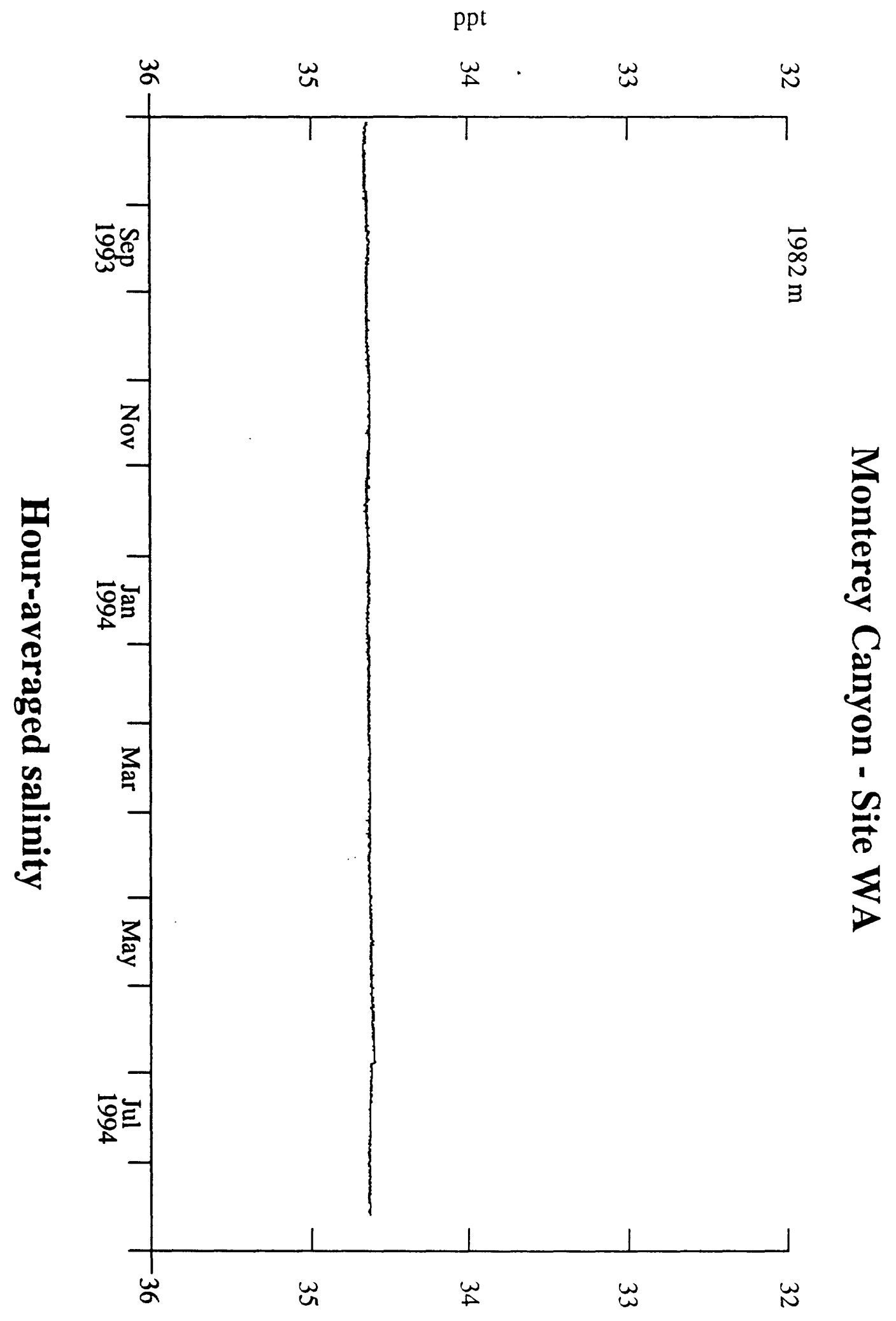

E-16 


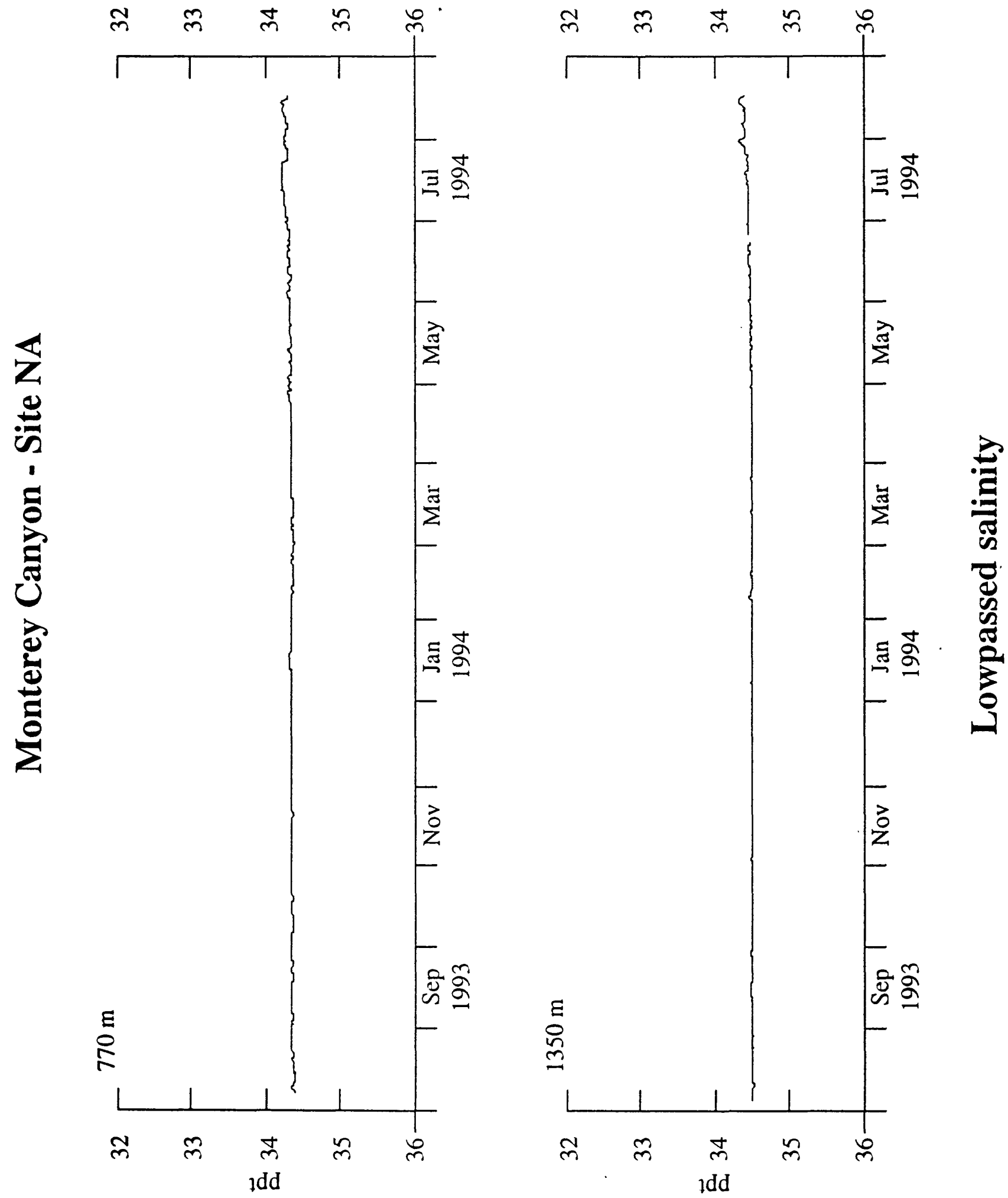



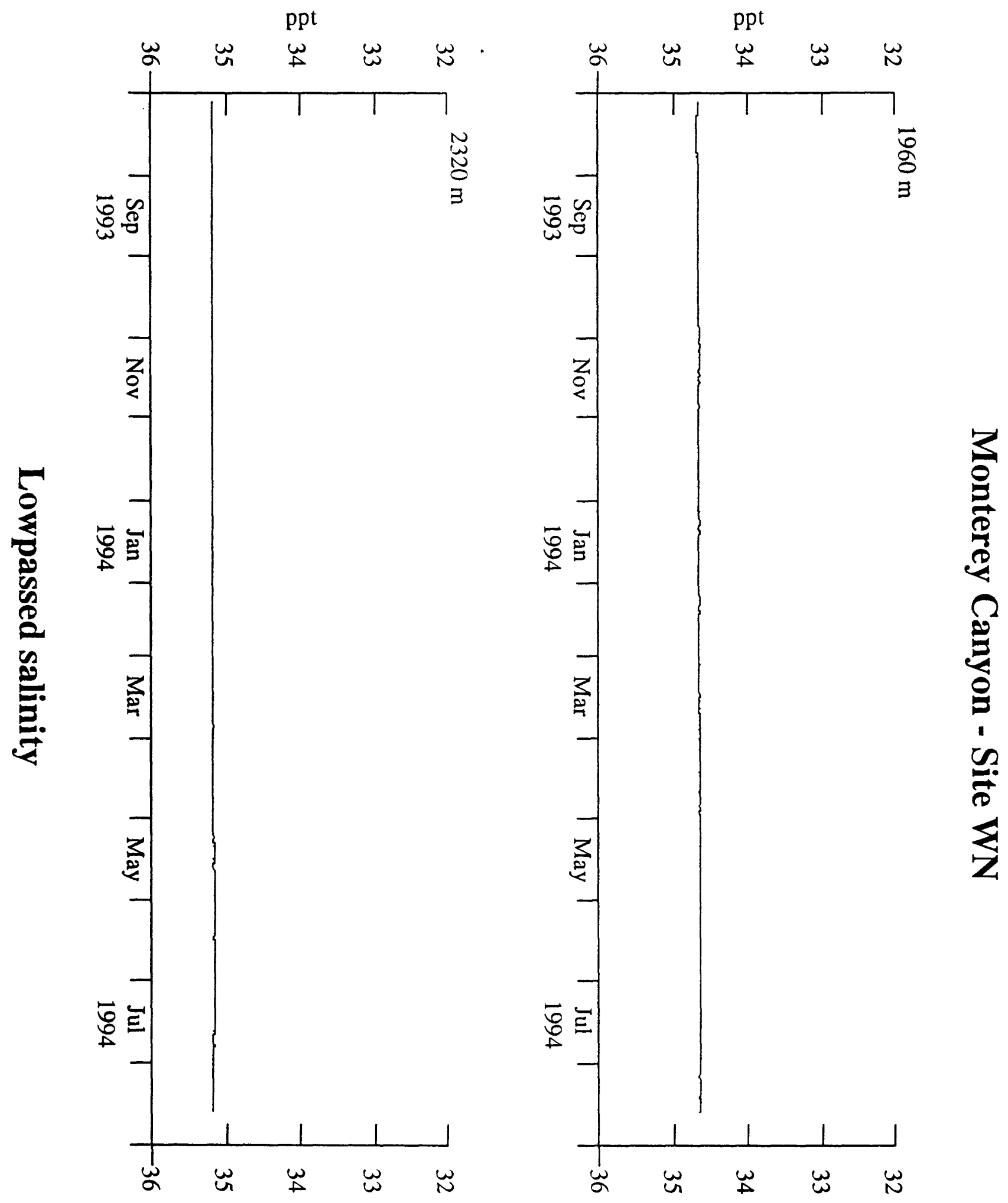


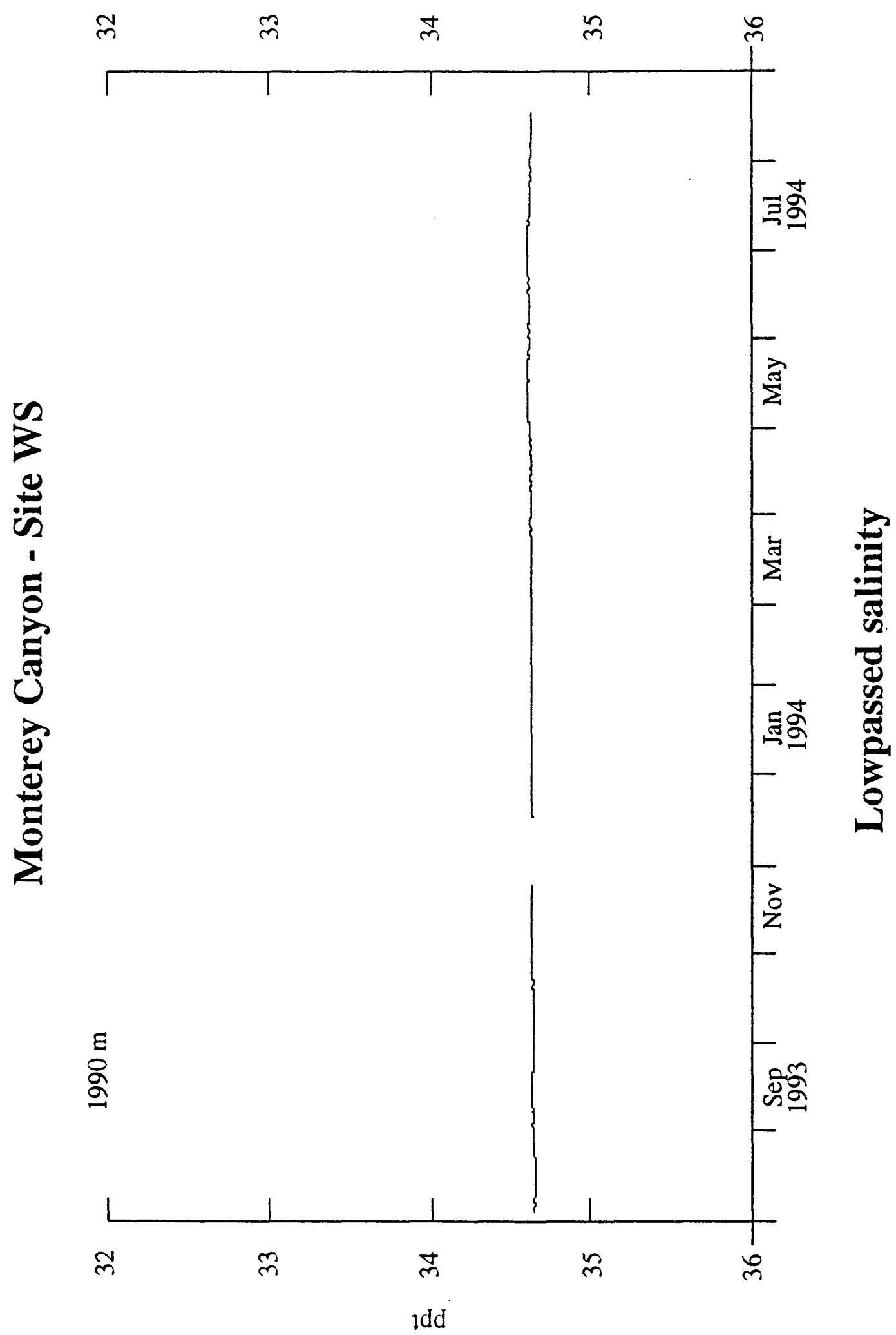

E-19 


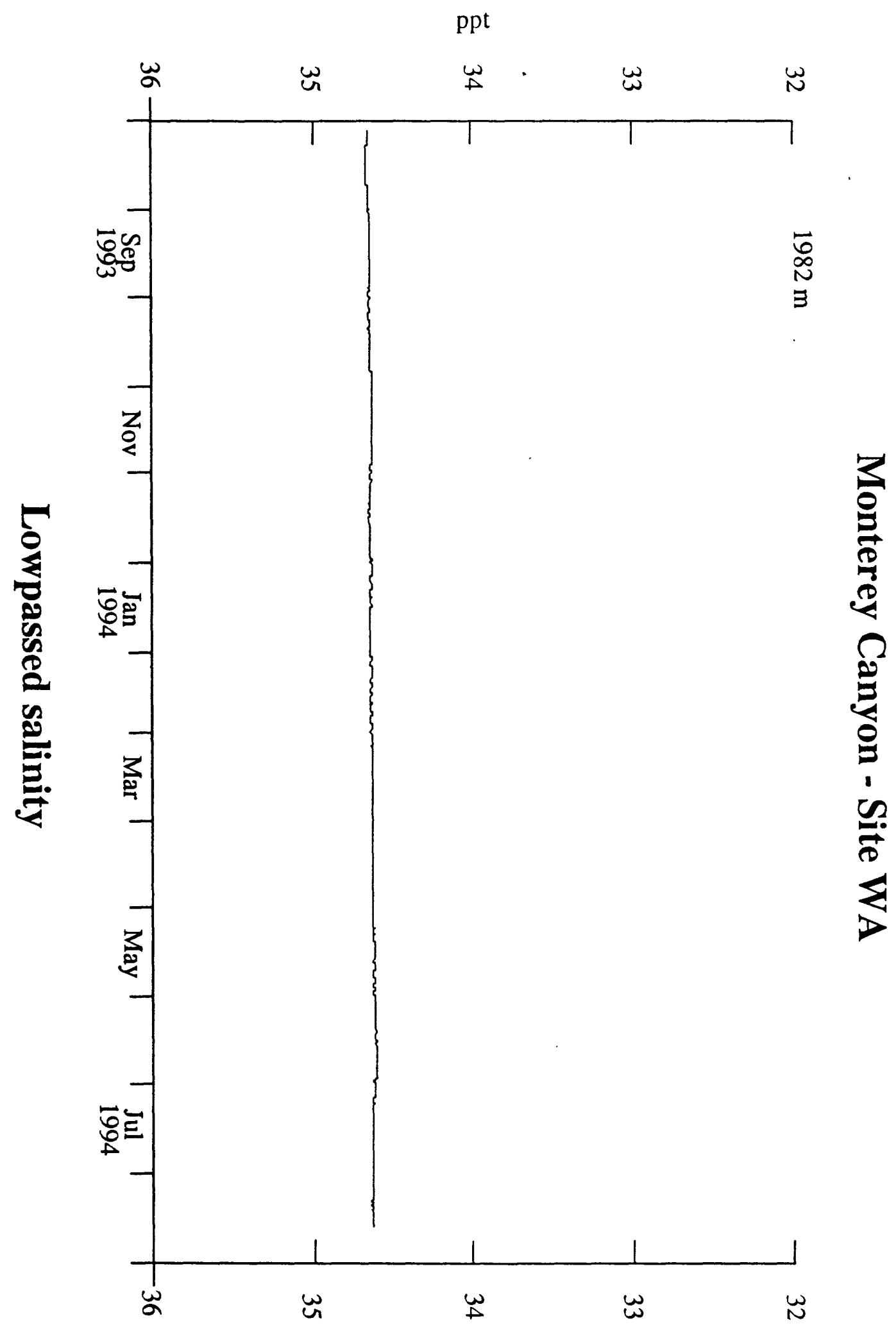



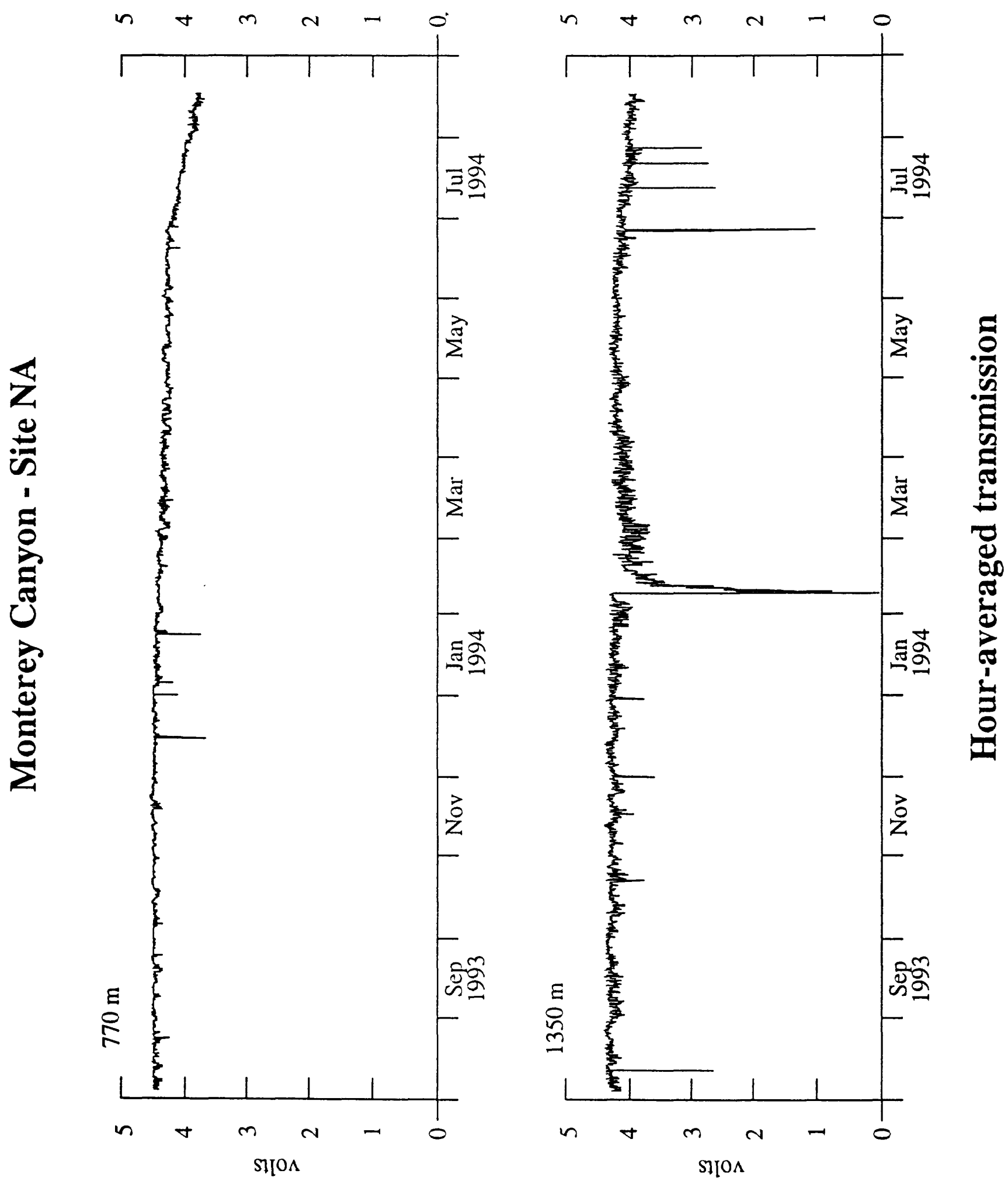

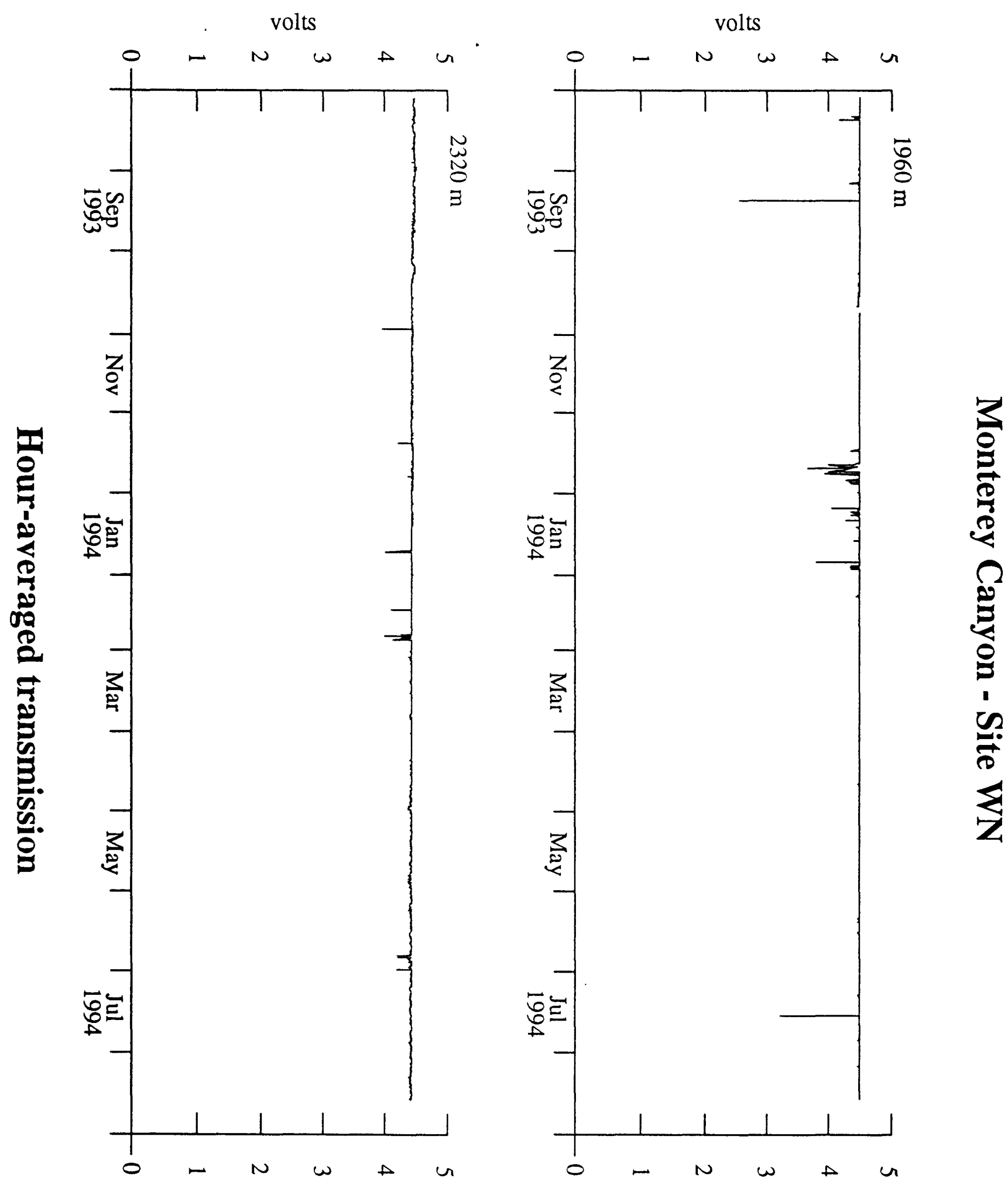


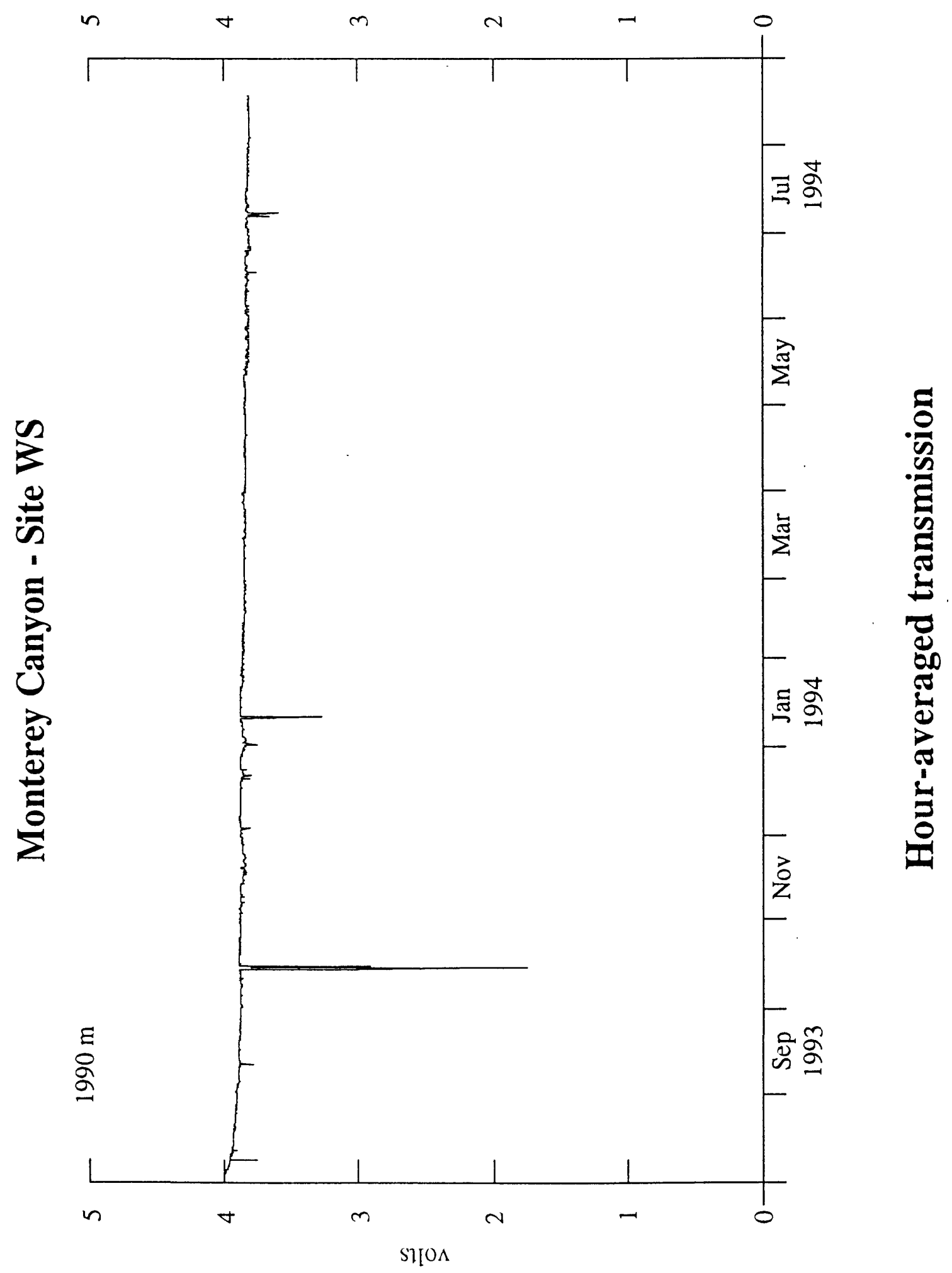




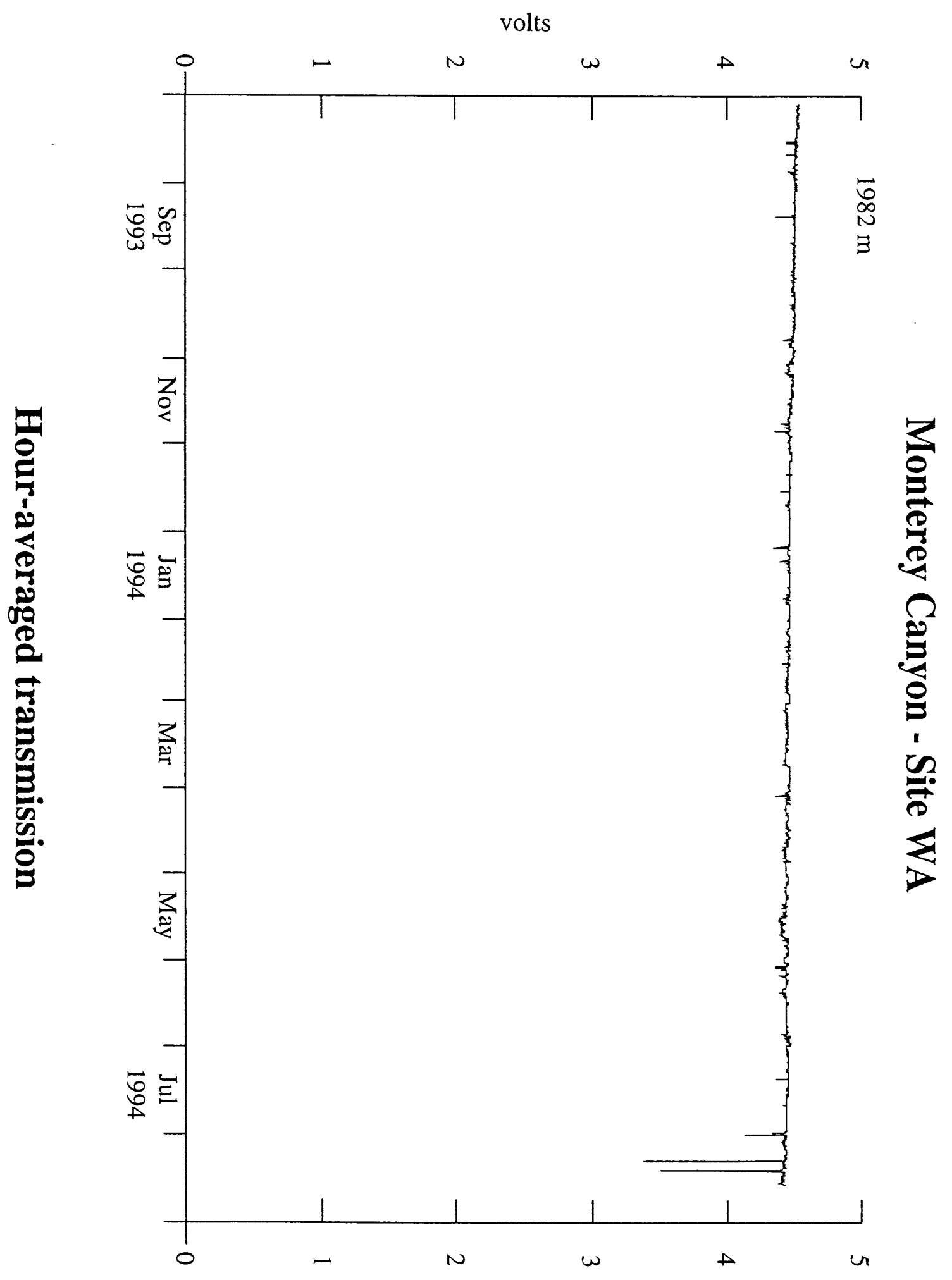




\section{Appendix F - Wind and sea level}

Table F1. - Dates \& piece length for wind \& sea lev spect plots .................. F1

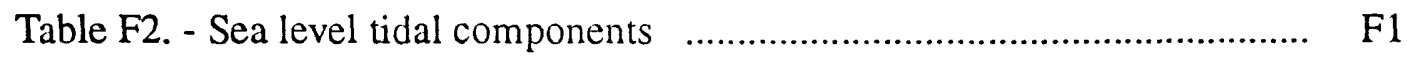

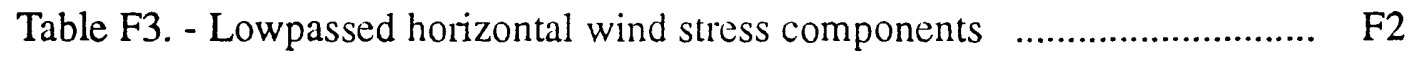

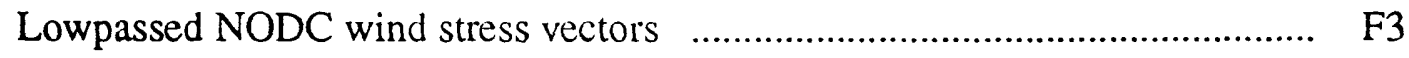

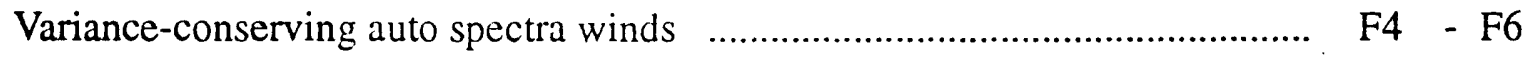

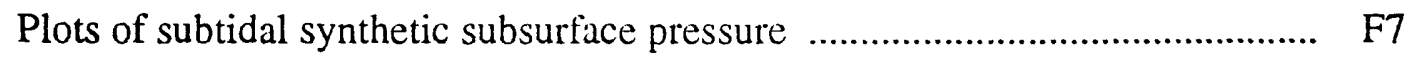

Variance-conserving auto spectra subtidal synthetic subsurface pressure $\quad \ldots . . . . \quad$ F8 


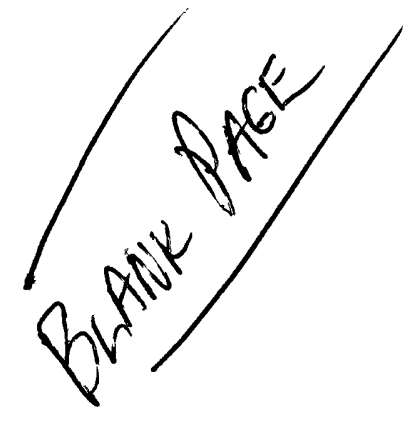




\begin{tabular}{|l|c|c|c|}
\hline \multicolumn{1}{|c|}{ Station } & $\begin{array}{c}\text { Start time } \\
\text { GMT } \\
\text { (M/D/Y) }\end{array}$ & $\begin{array}{c}\text { Stop time } \\
\text { GMT } \\
\text { (M/D/Y) }\end{array}$ & $\begin{array}{c}\text { Piece length } \\
\text { (hours) }\end{array}$ \\
\hline \hline Buoy winds & & & \\
Half Moon Bay (46012) & $12 / 03 / 93$ & $07 / 15 / 94$ & 294 \\
Bodega Bay (46013) & $08 / 01 / 93$ & $08 / 13 / 94$ & 624 \\
Monterey Bay (46042) & $08 / 01 / 93$ & $08 / 13 / 94$ & 624 \\
& & & \\
\hline Sea level & & & \\
Monterey Harbor & $08 / 0393$ & $07 / 14 / 94$ & 460 \\
Port San Luis & $08 / 03 / 93$ & $07 / 14 / 94$ & 460 \\
\hline
\end{tabular}

Table F1. Dates and piece lengths used for wind and sea level spectral plots.

\begin{tabular}{|l|l|l|l|l|l|l|}
\hline \multicolumn{1}{|c|}{ Station } & $\begin{array}{c}\text { Start time } \\
(\mathrm{GMT}) \\
(\mathrm{M} / \mathrm{D} / \mathrm{Y})\end{array}$ & $\begin{array}{c}\text { Stop time } \\
\mathrm{GMT} \\
(\mathrm{M} / \mathrm{D} / \mathrm{Y})\end{array}$ & $\begin{array}{c}\mathrm{O}_{1} \\
(\mathrm{~cm})\end{array}$ & $\begin{array}{c}\mathrm{K}_{1} \\
(\mathrm{~cm})\end{array}$ & $\begin{array}{c}\mathrm{M}_{2} \\
(\mathrm{~cm})\end{array}$ & $\begin{array}{c}\mathrm{S}_{2} \\
(\mathrm{~cm})\end{array}$ \\
\hline \multirow{3}{*}{ Monterey Harbor } & $08 / 01 / 93$ & $07 / 17 / 94$ & 22.9 & 36.6 & 49.2 & 13.6 \\
Port San Luis & $07 / 25 / 94$ & $09 / 01 / 94$ & 22.4 & 36.3 & 49.4 & 13.4 \\
& $08 / 01 / 93$ & $09 / 01 / 94$ & 22.2 & 35.7 & 49.4 & 15.4 \\
& $07 / 25 / 94$ & $09 / 01 / 94$ & 21.7 & 35.7 & 49.3 & 14.9 \\
\hline
\end{tabular}

Table F2. Sea level tidal components. 


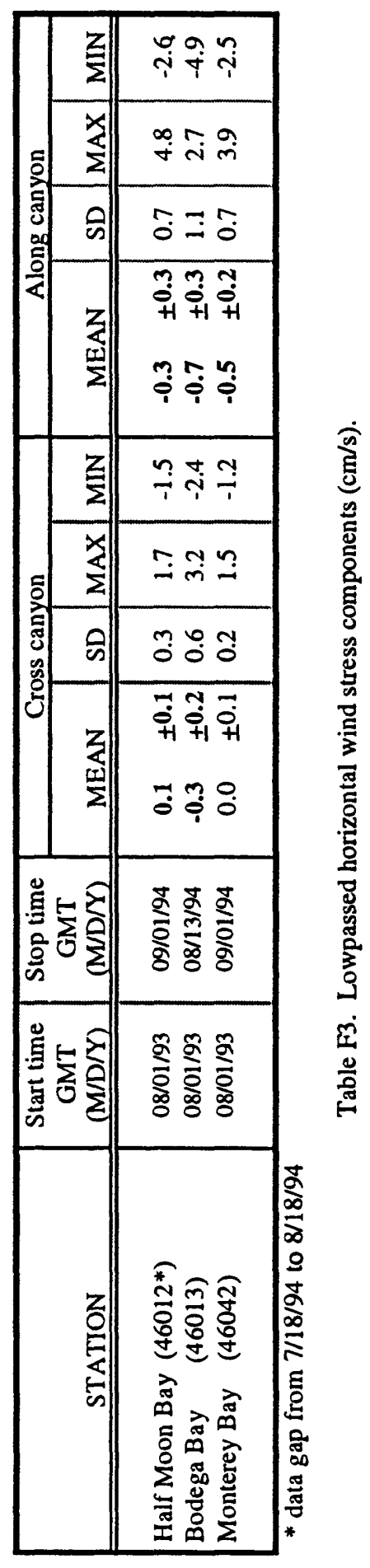



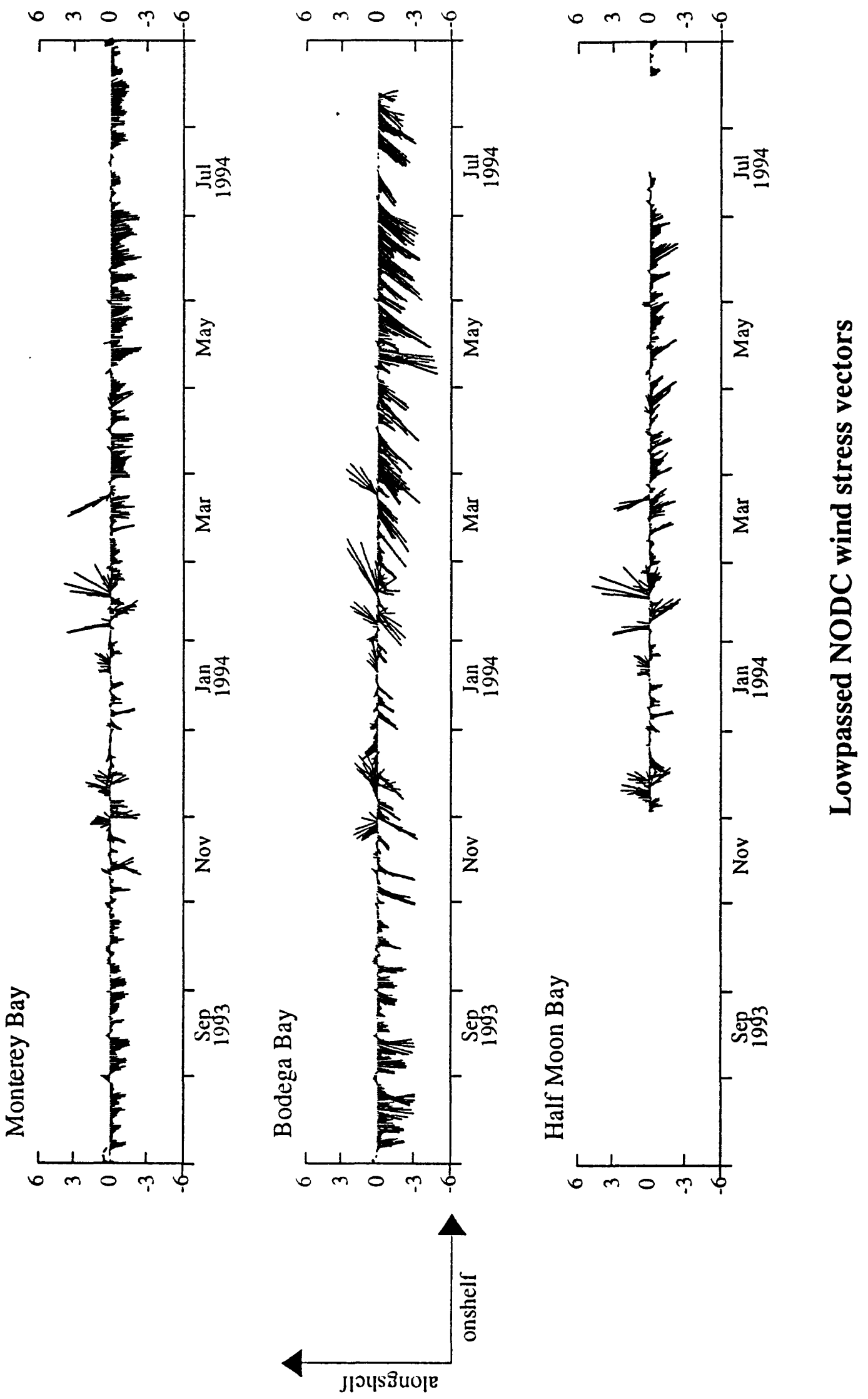

F-3 


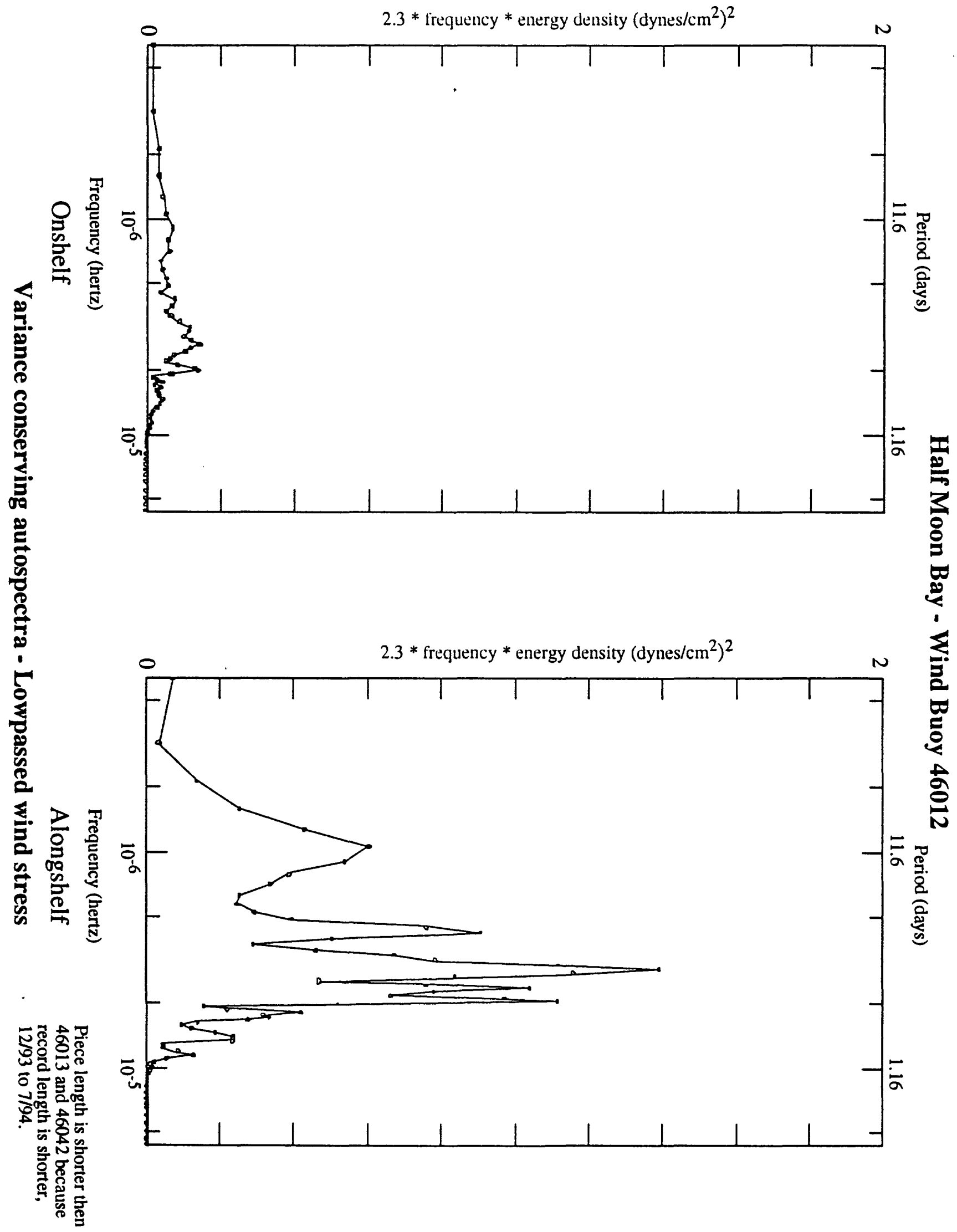




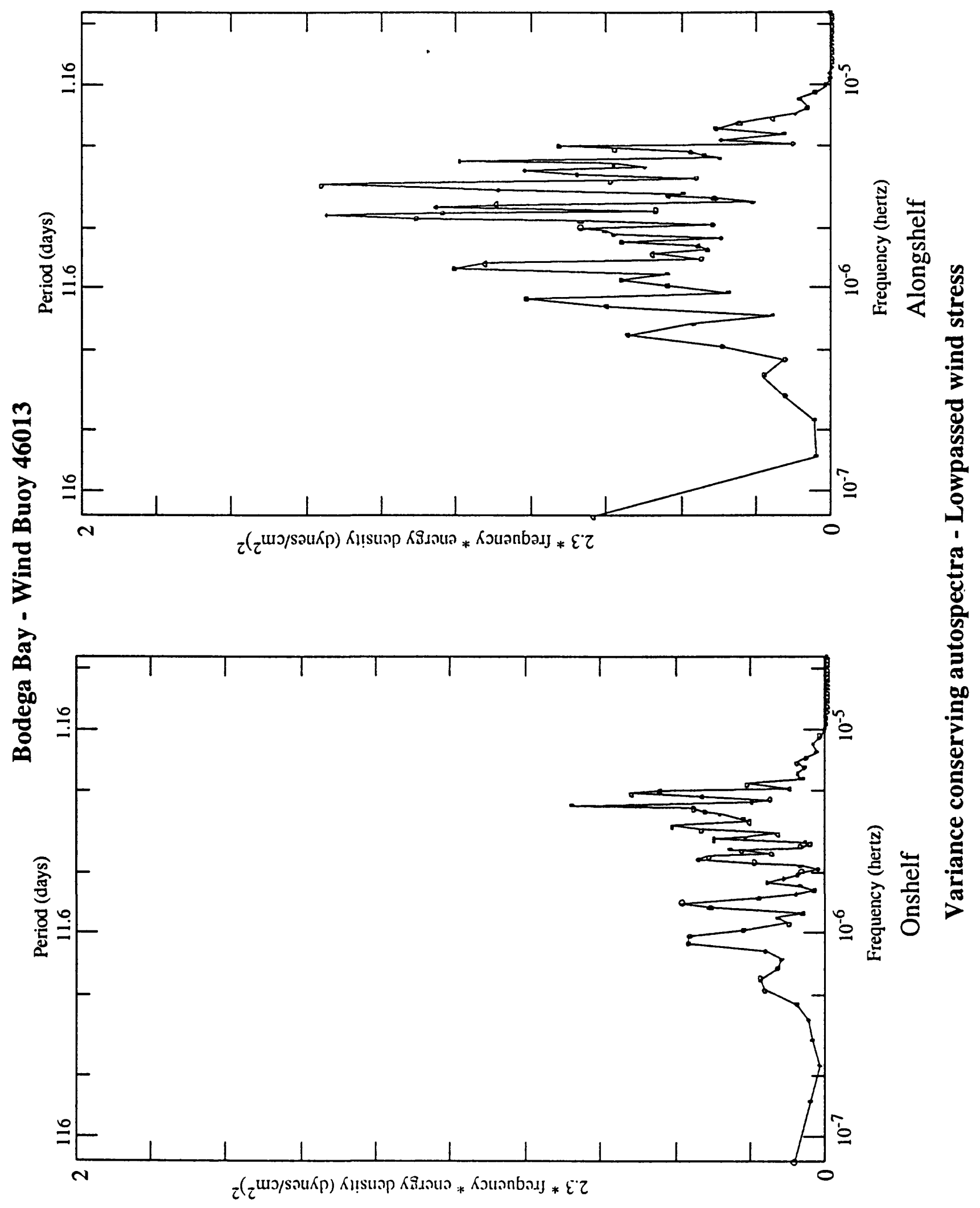




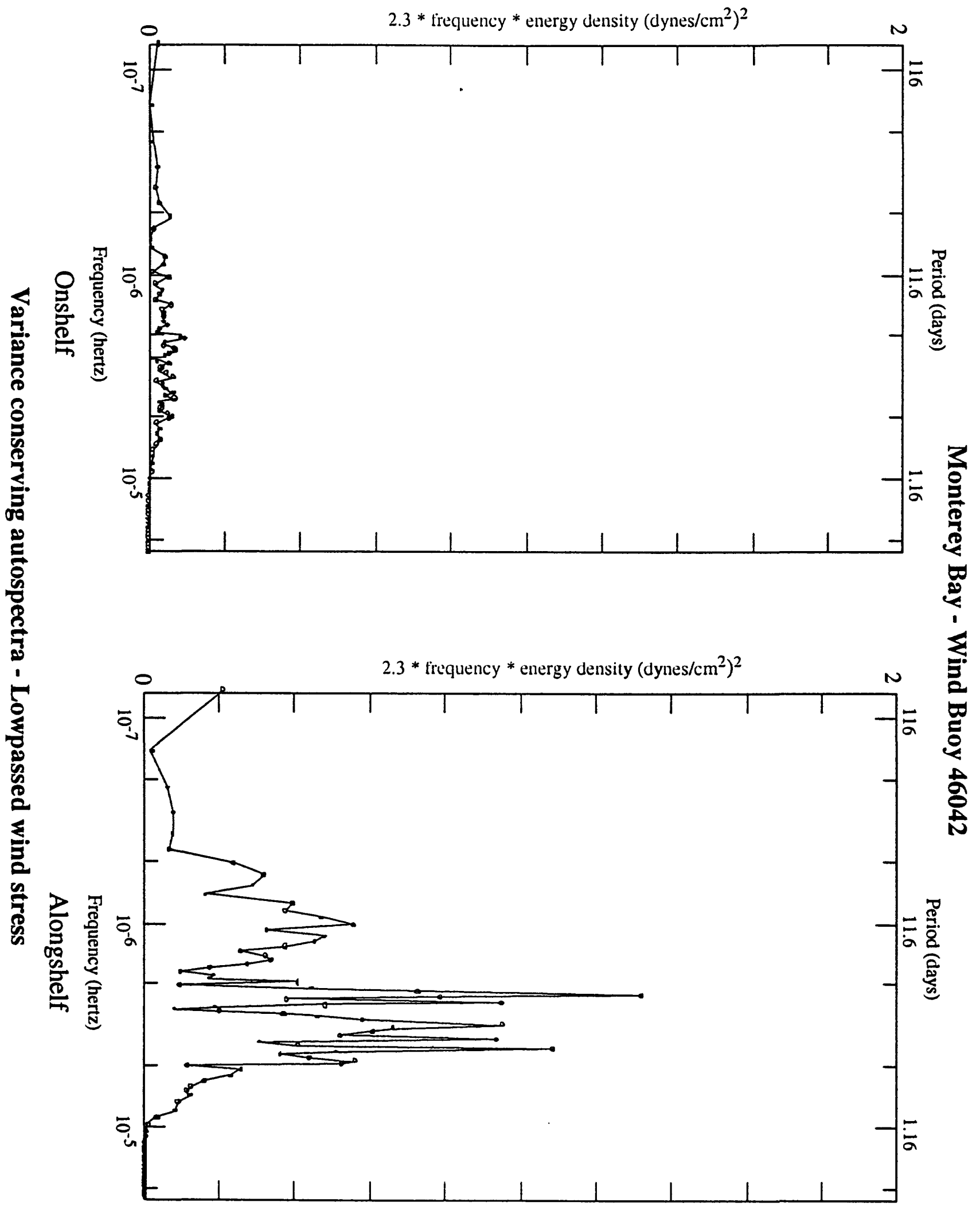




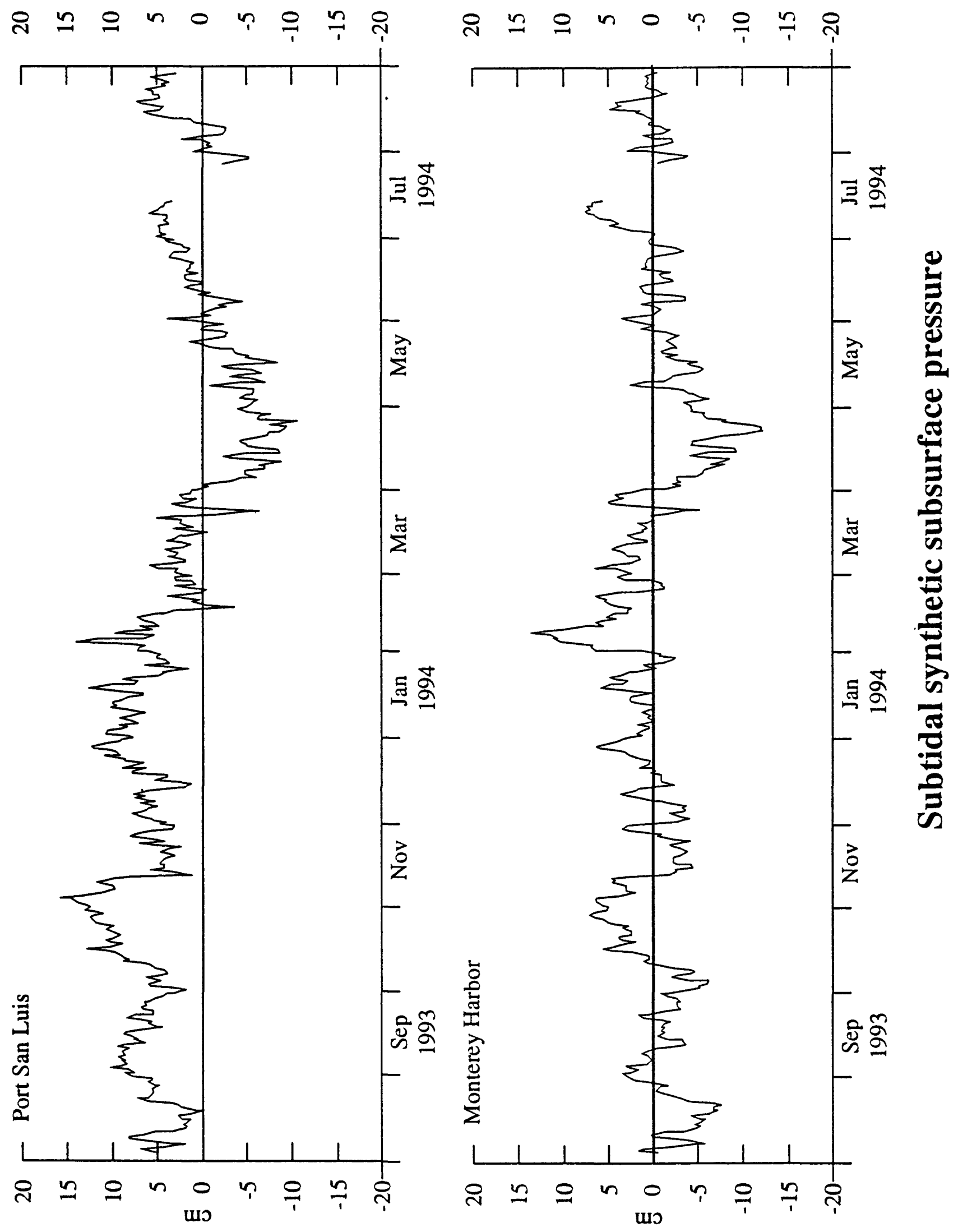



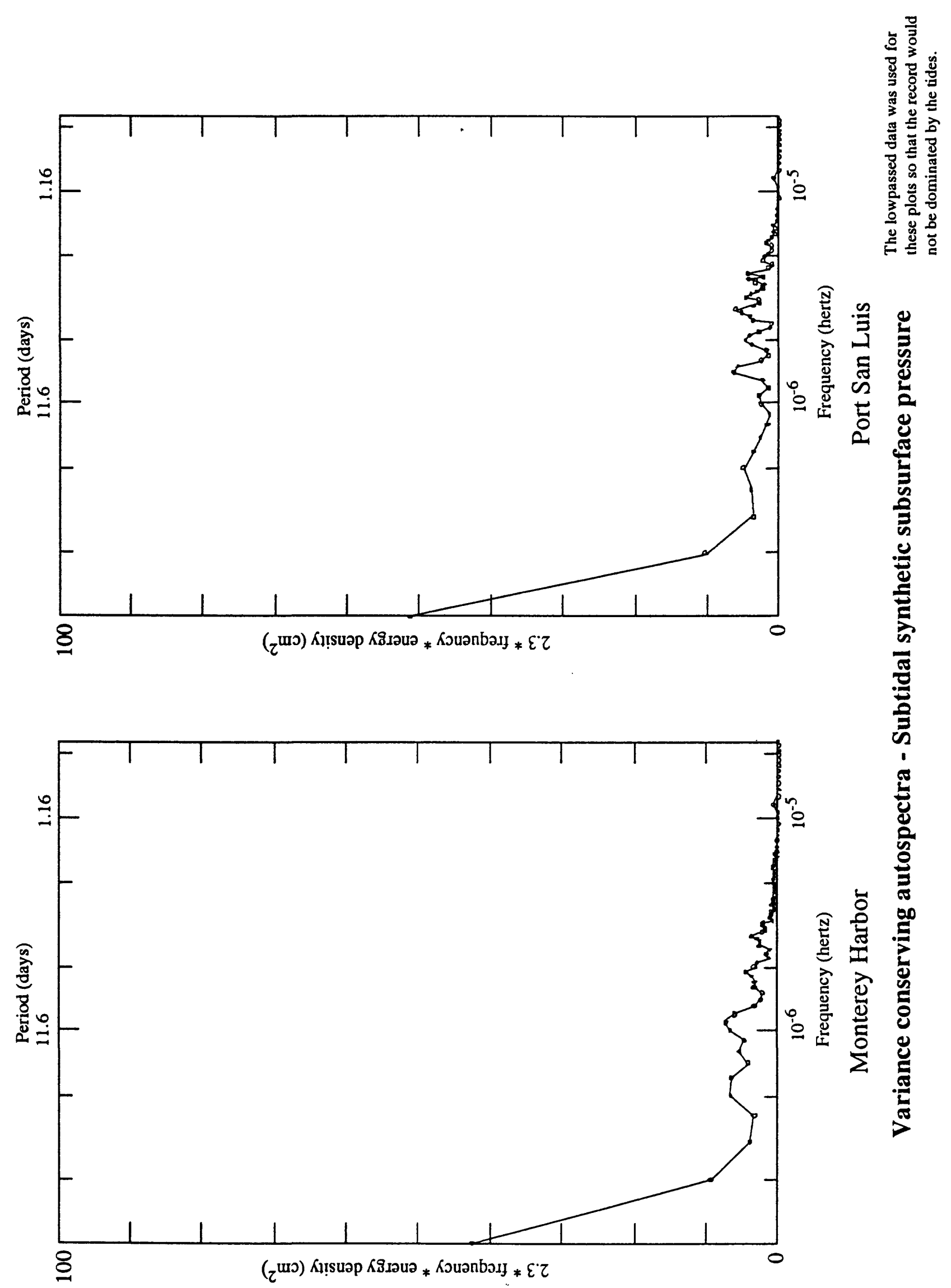

F-8 


\section{Appendix G - Additional data for Monterey Fan mooring 1994-1995}

Figure G1 - Mooring set-up for fan

G1

Figure G2. - Timelines

G2

Table G1. - Data available

G3

Table G2. - Hour-averaged horizontal current components

G4

Table G3. - Lowpassed horizontal currentcomponents

G4

Table G4. - Hour-averaged temperature and salinity G5

Table G5. - Lowpassed temperature and salinity G5

Table G6. - Diurnal tidal currents G6

Table G7. - Semi-diurnal tidal currents G7

Plots of hour-averaged currents G8 - G9

Plots of subtidal currents G10 - G11

Plots of subtidal current vectors G12

Table G8. - Dates and piece lengths used for current spectral plots G13

Variance conserving auto spectra G14 - G15

Plots of hour-averaged temperature G16

Plots of lowpassed temperature G17

Plots of hour-averaged salinity G18

Plots of lowpassed salinity G19 


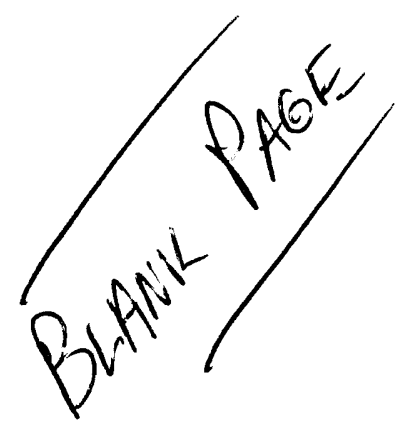




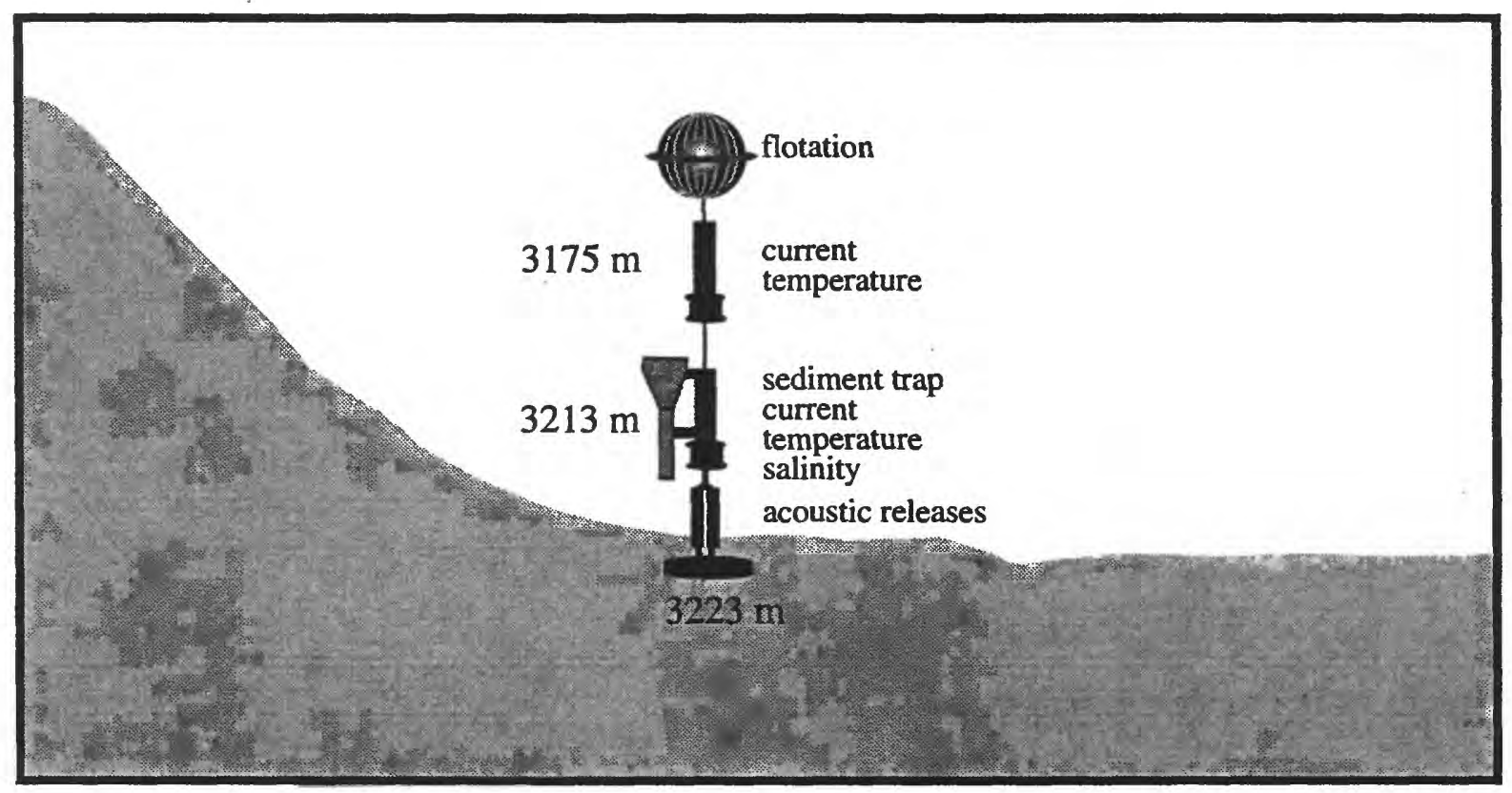

Figure G1. Cross section view of mooring (1994-1995) set-up on Monterey Fan. 

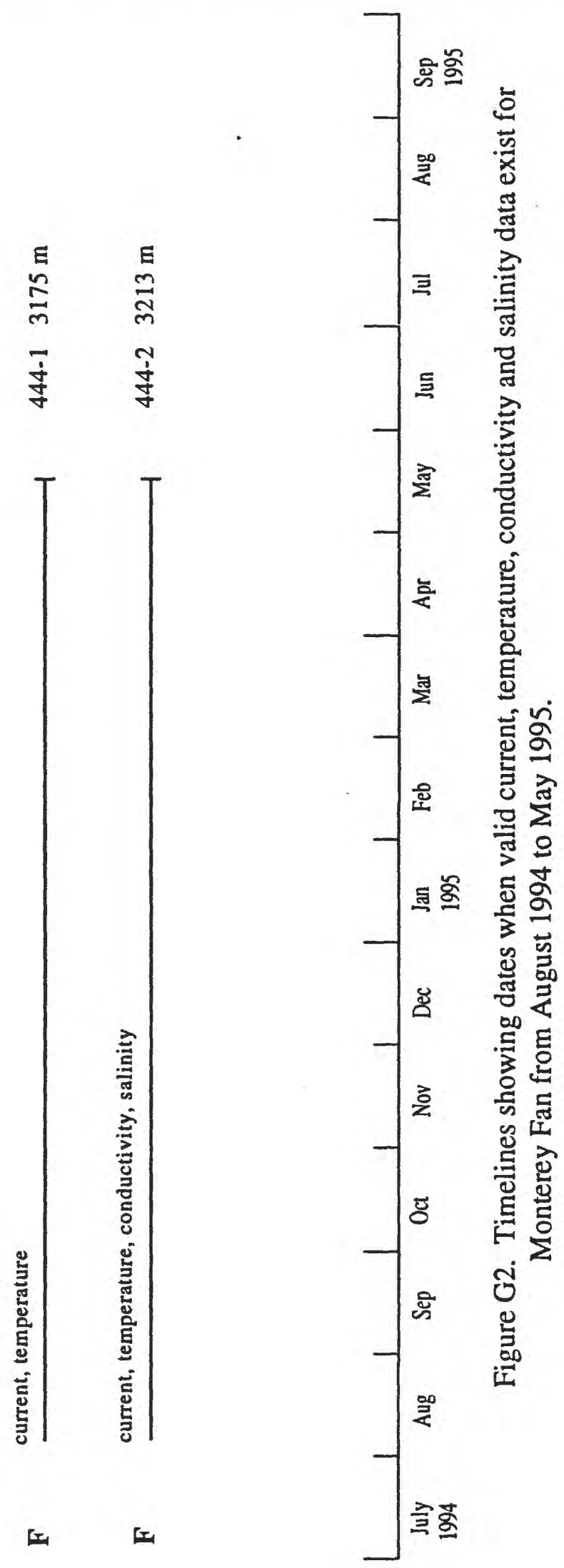


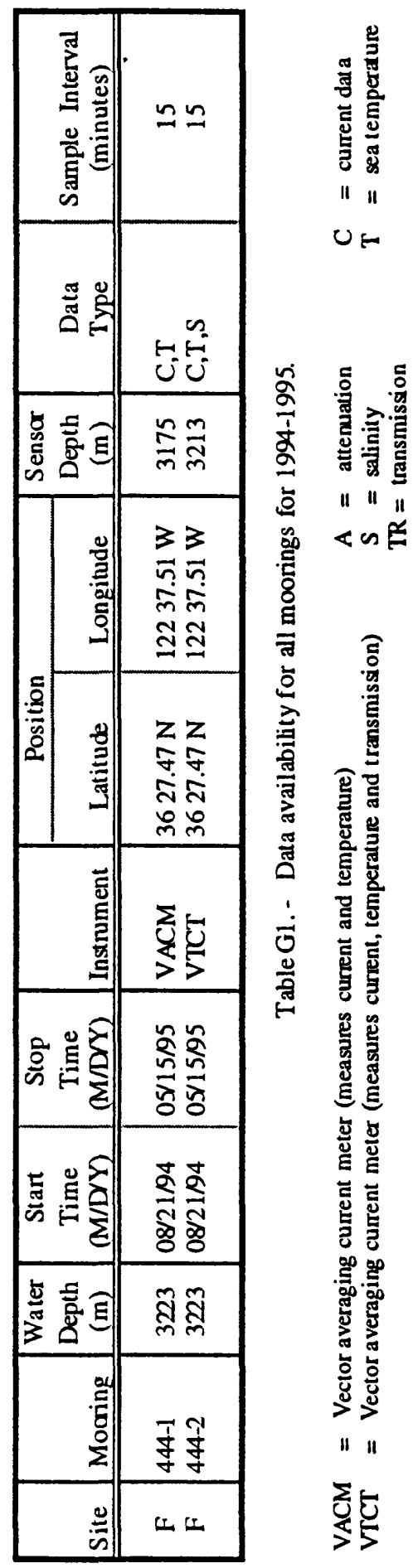



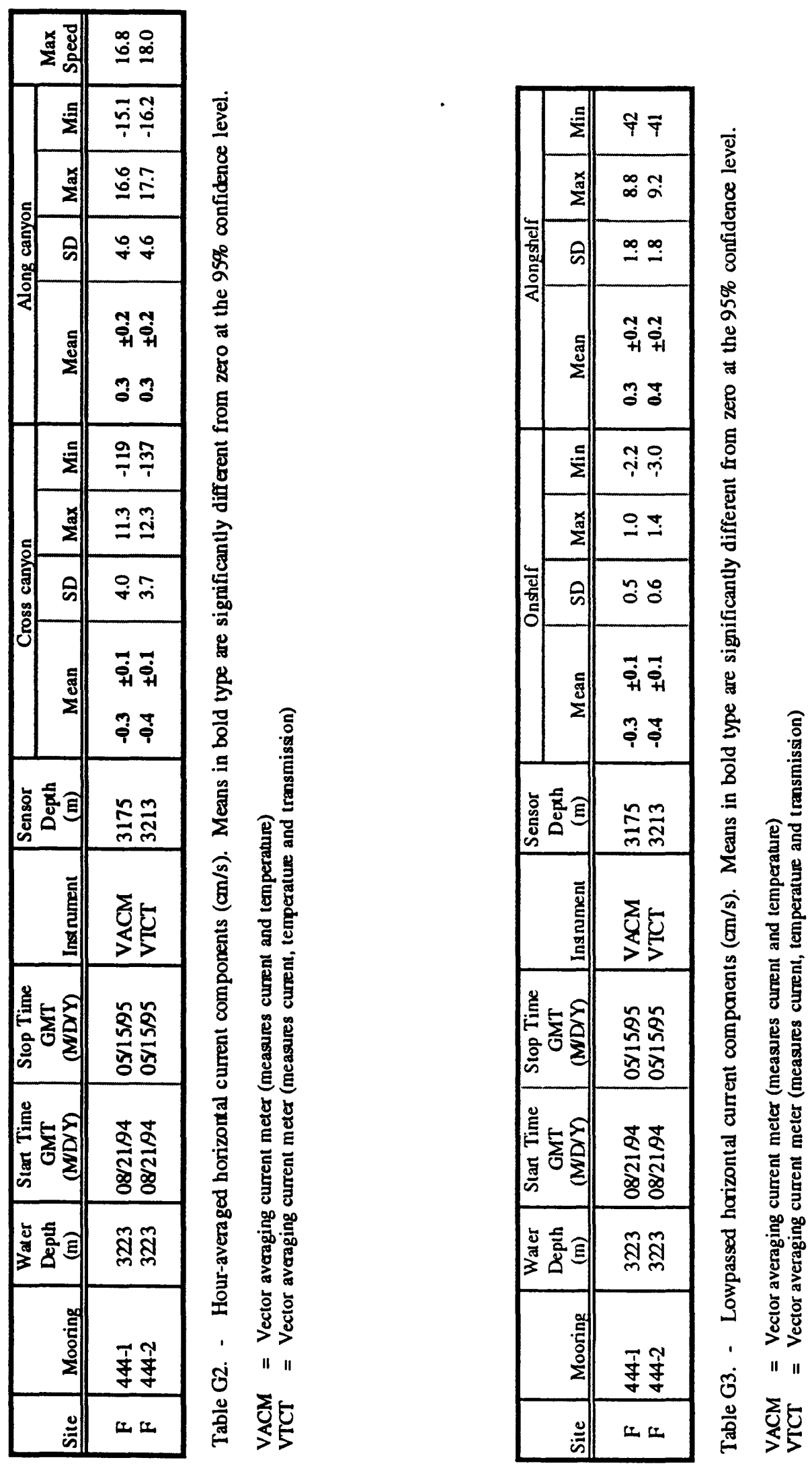

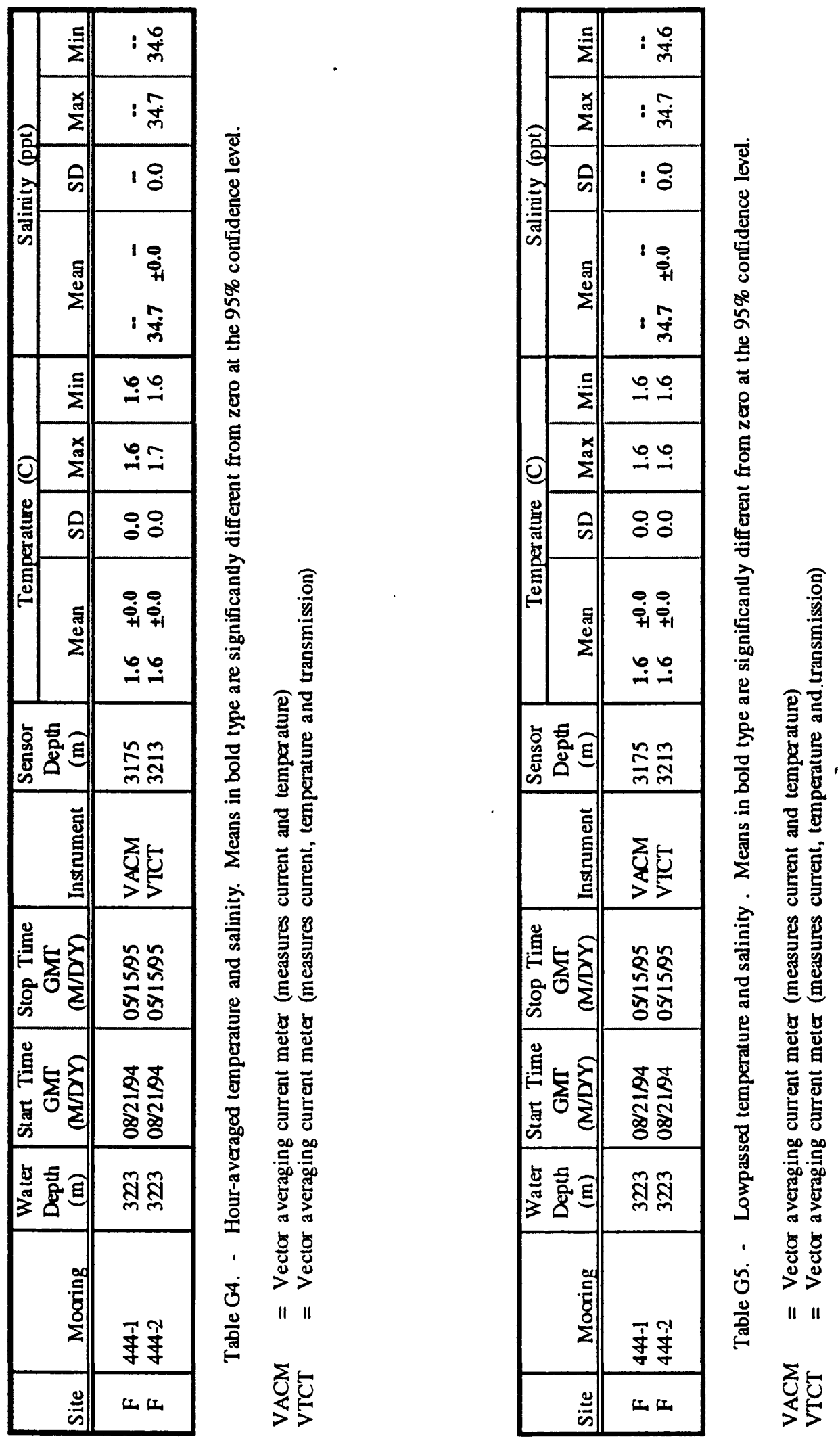


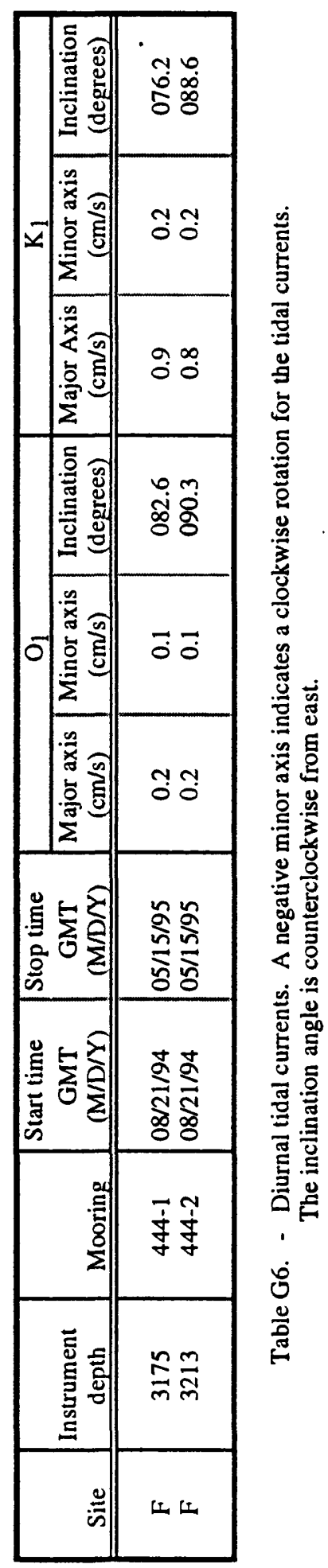




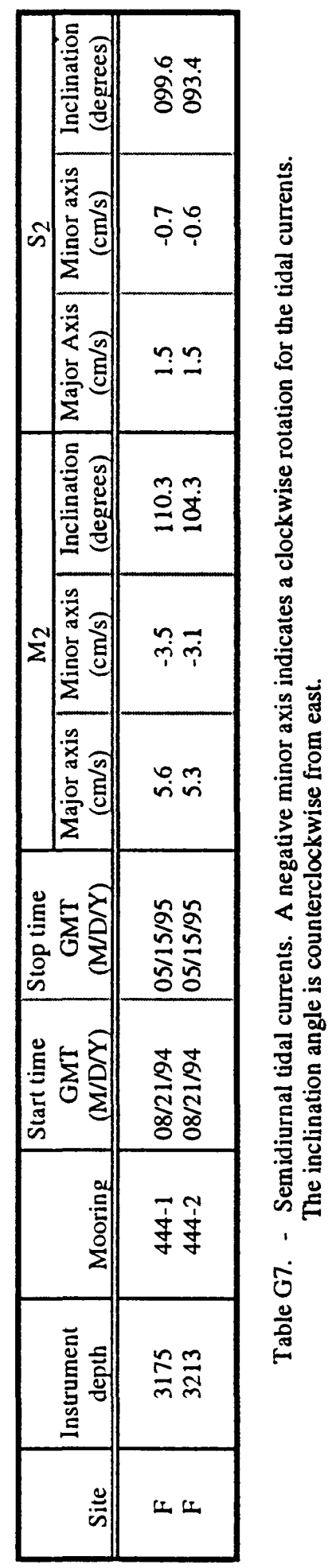




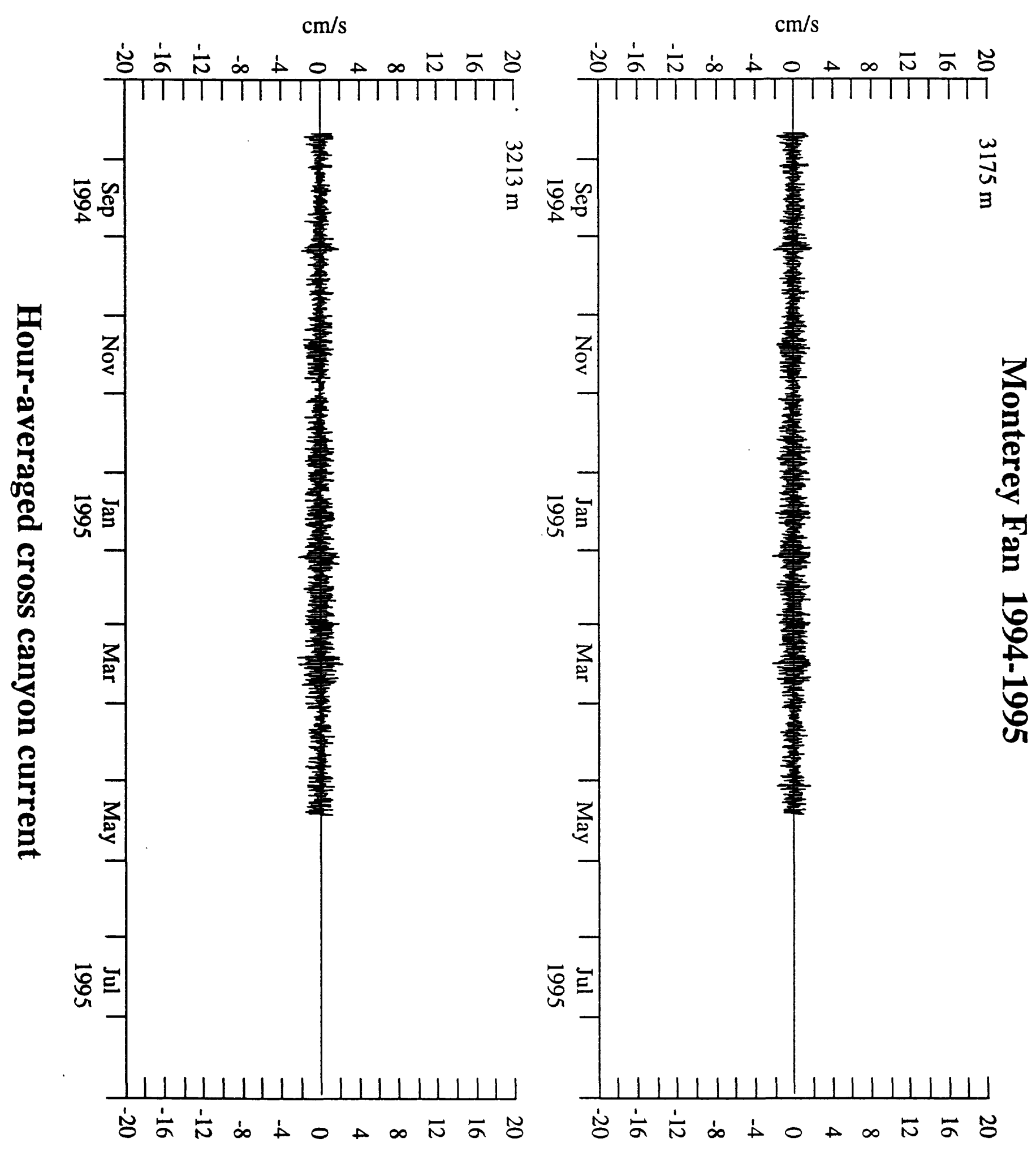




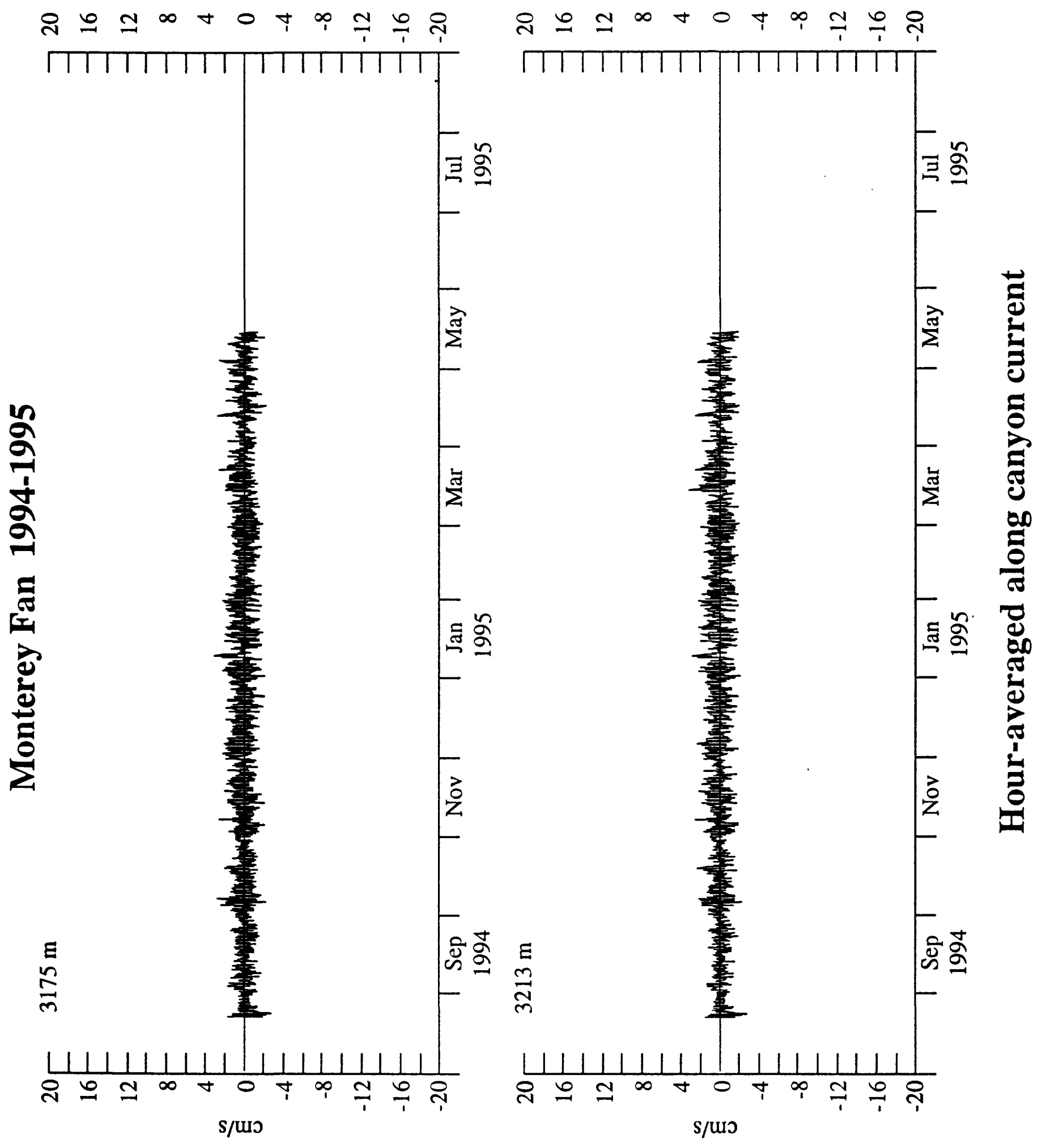




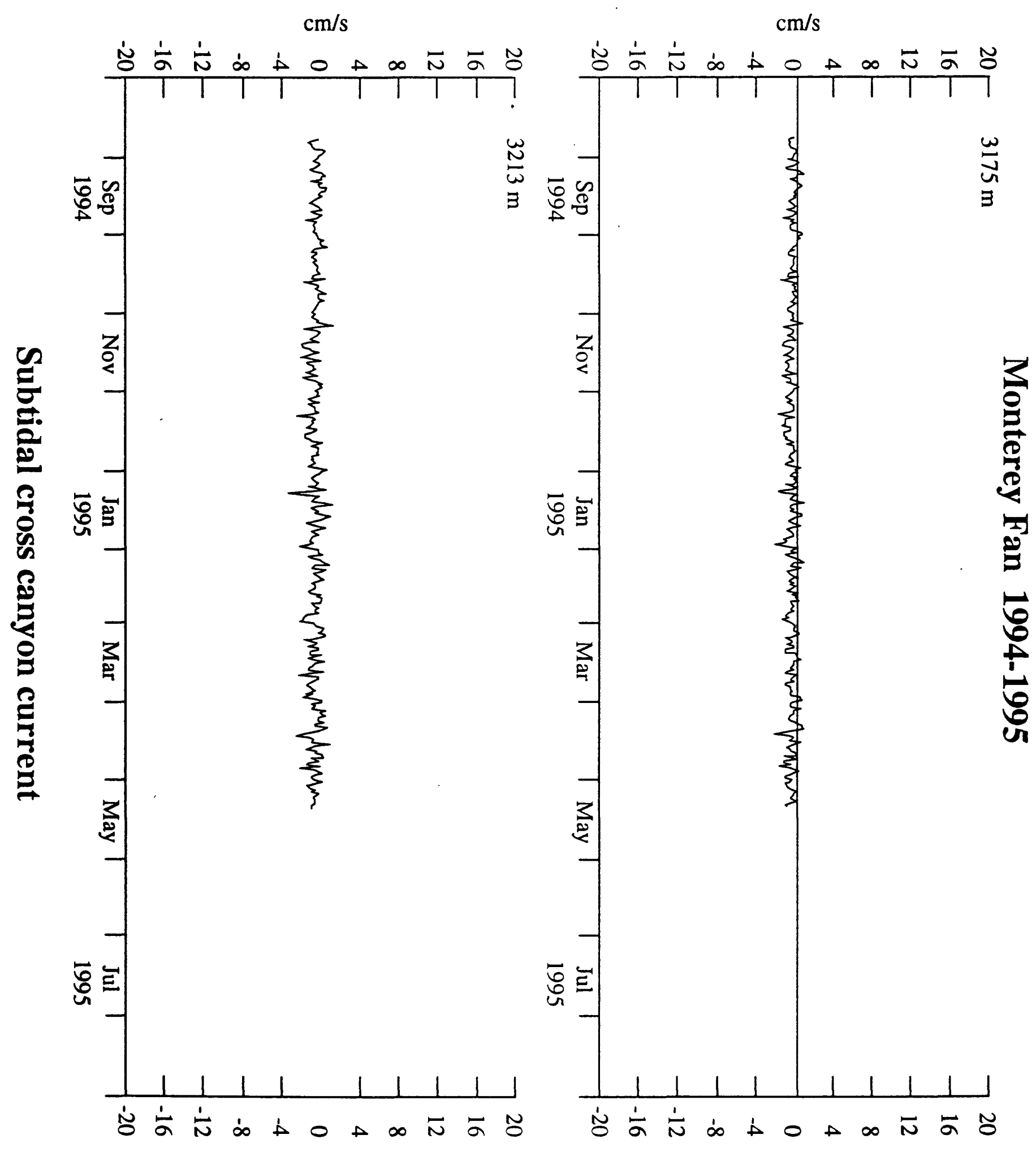




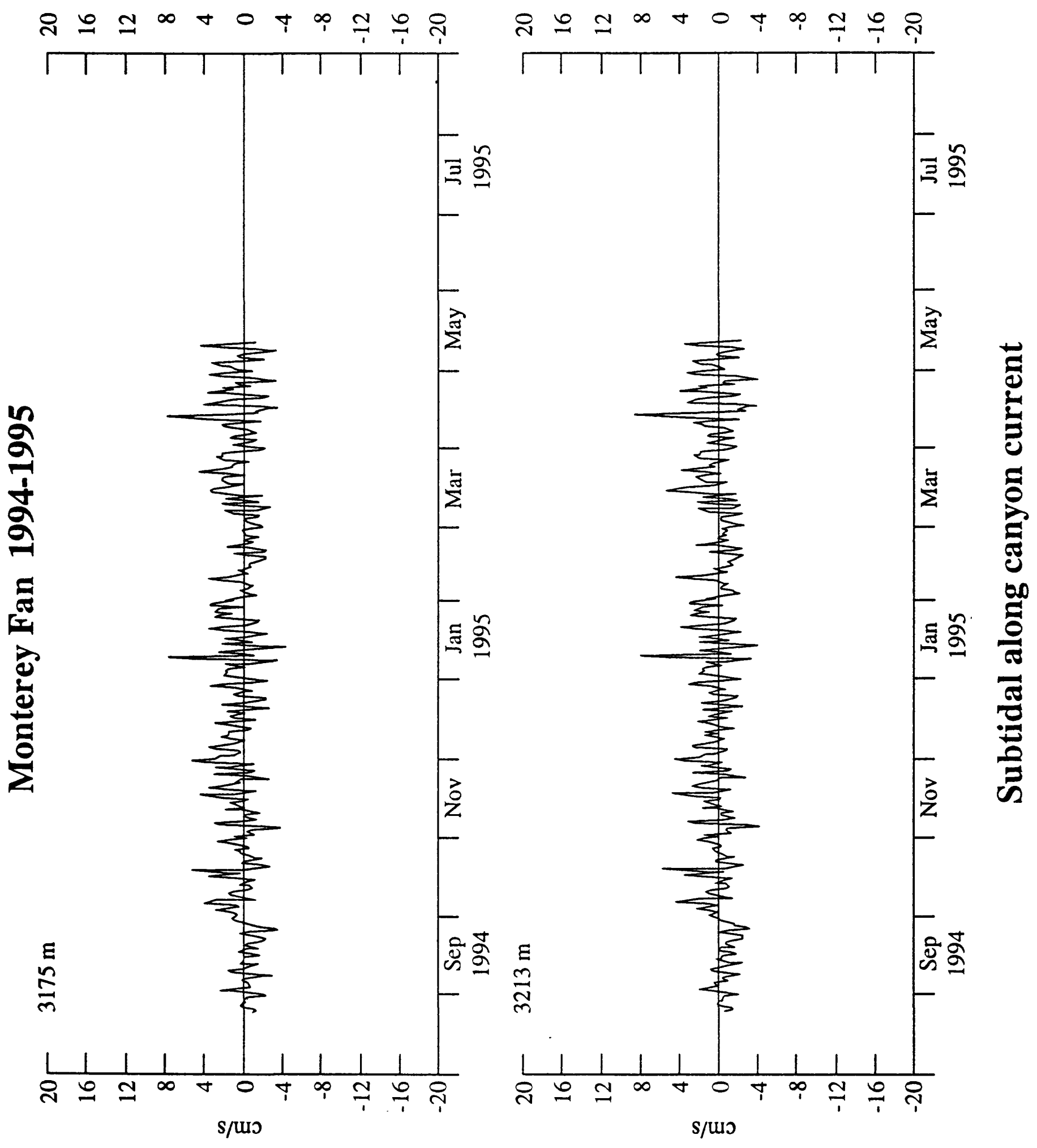



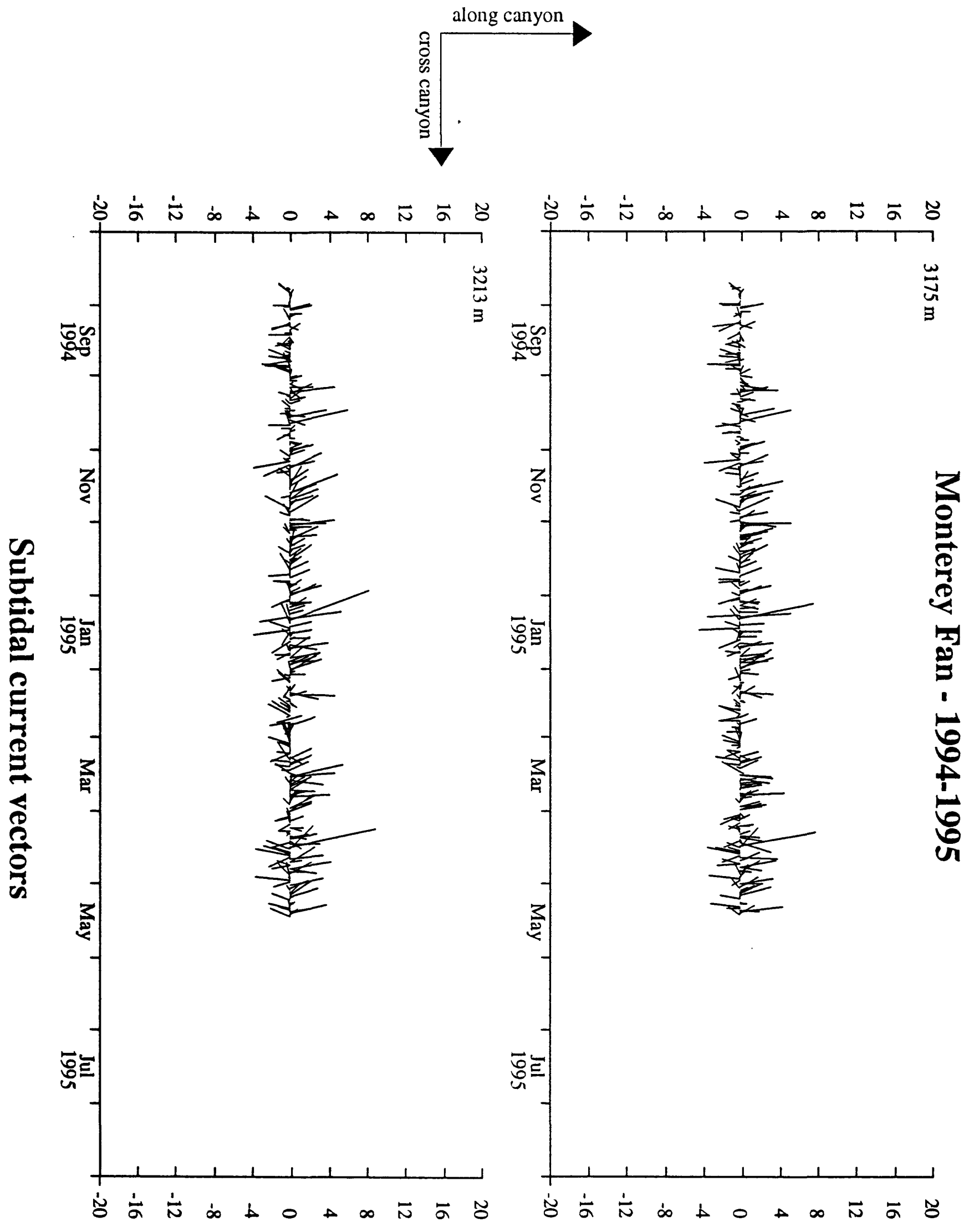


\begin{tabular}{|c|ccc|c|c|}
\hline Site & Mooring & $\begin{array}{c}\text { Sensor } \\
\text { Depth } \\
(\mathrm{m})\end{array}$ & $\begin{array}{c}\text { Start time } \\
\text { GMT } \\
(\mathrm{M} / \mathrm{D} / \mathrm{Y})\end{array}$ & $\begin{array}{c}\text { Stop time } \\
\text { GMT } \\
(\mathrm{M} / \mathrm{D} / \mathrm{Y})\end{array}$ & $\begin{array}{c}\text { Piece length } \\
\text { hours }\end{array}$ \\
\hline \hline & & & & & \\
F & $444-1$ & 3175 & $08 / 21 / 94$ & $05 / 15 / 95$ & 2112 \\
F & $444-2$ & 3213 & $08 / 21 / 94$ & $05 / 15 / 95$ & 2112 \\
\hline
\end{tabular}

Table G8 Dates and piece lengths used for the spectral plots for fan mooring 1994-1995. 
Appendix G - Additional data for Monterey Fan mooring 1994-1995

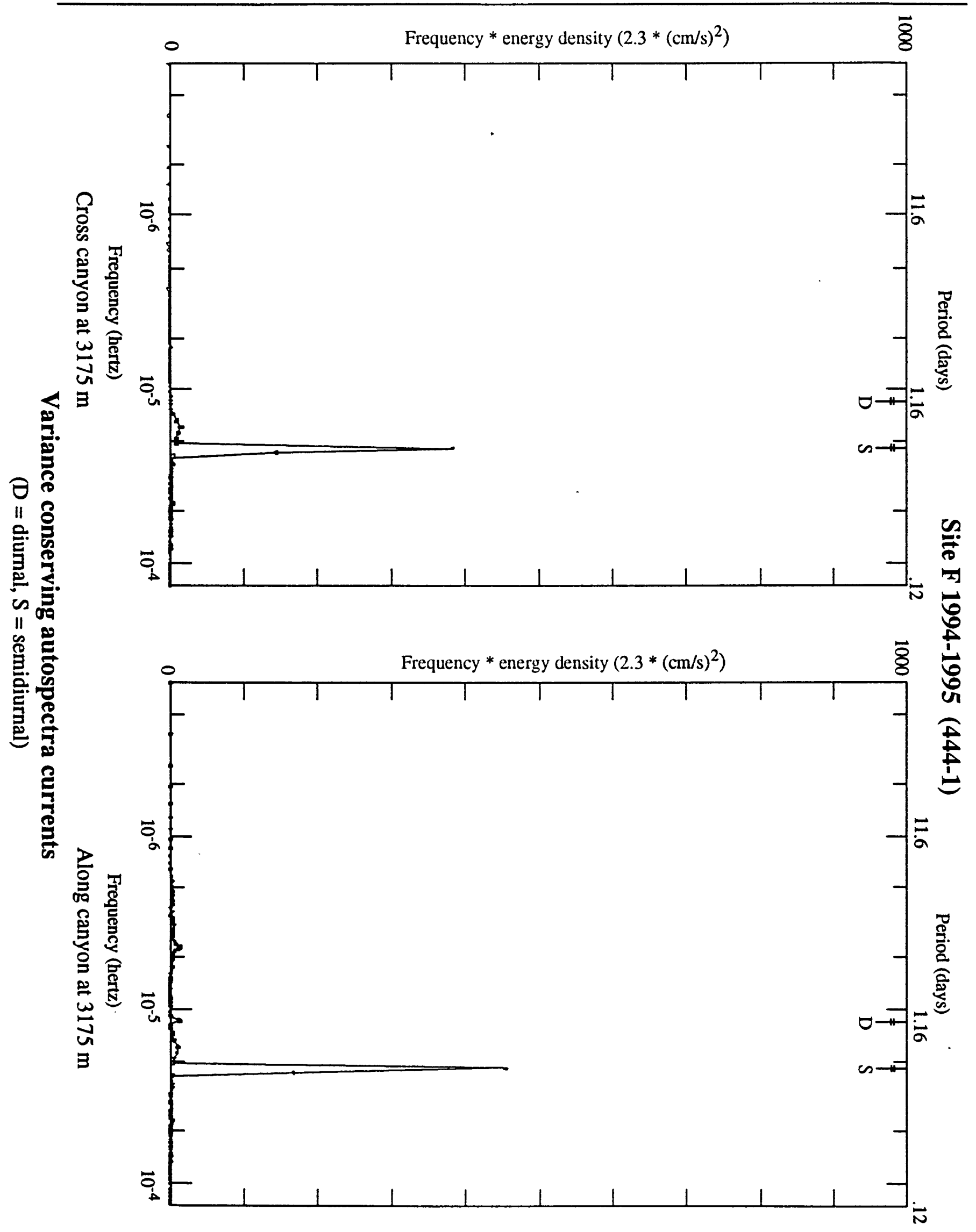

G-14 


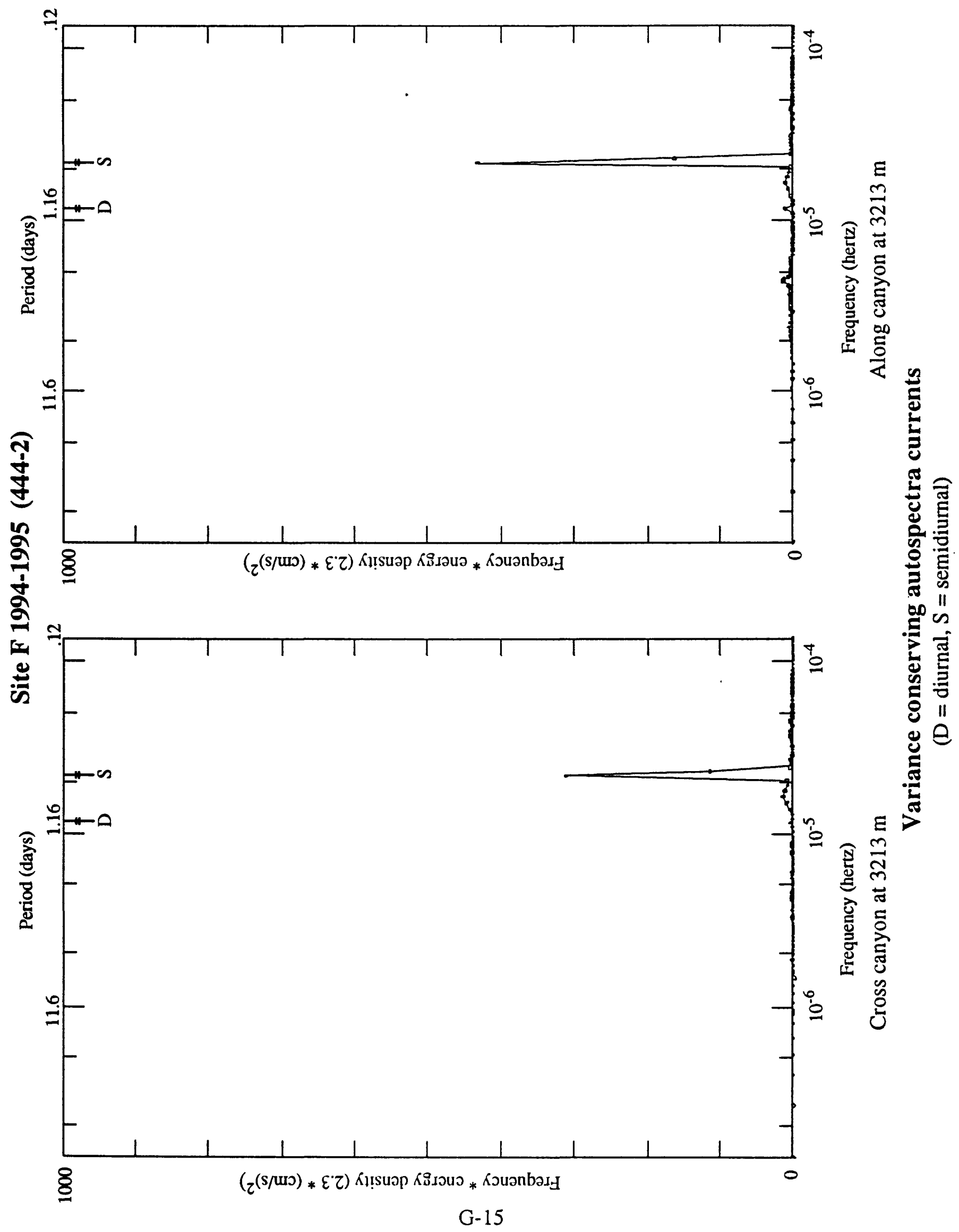



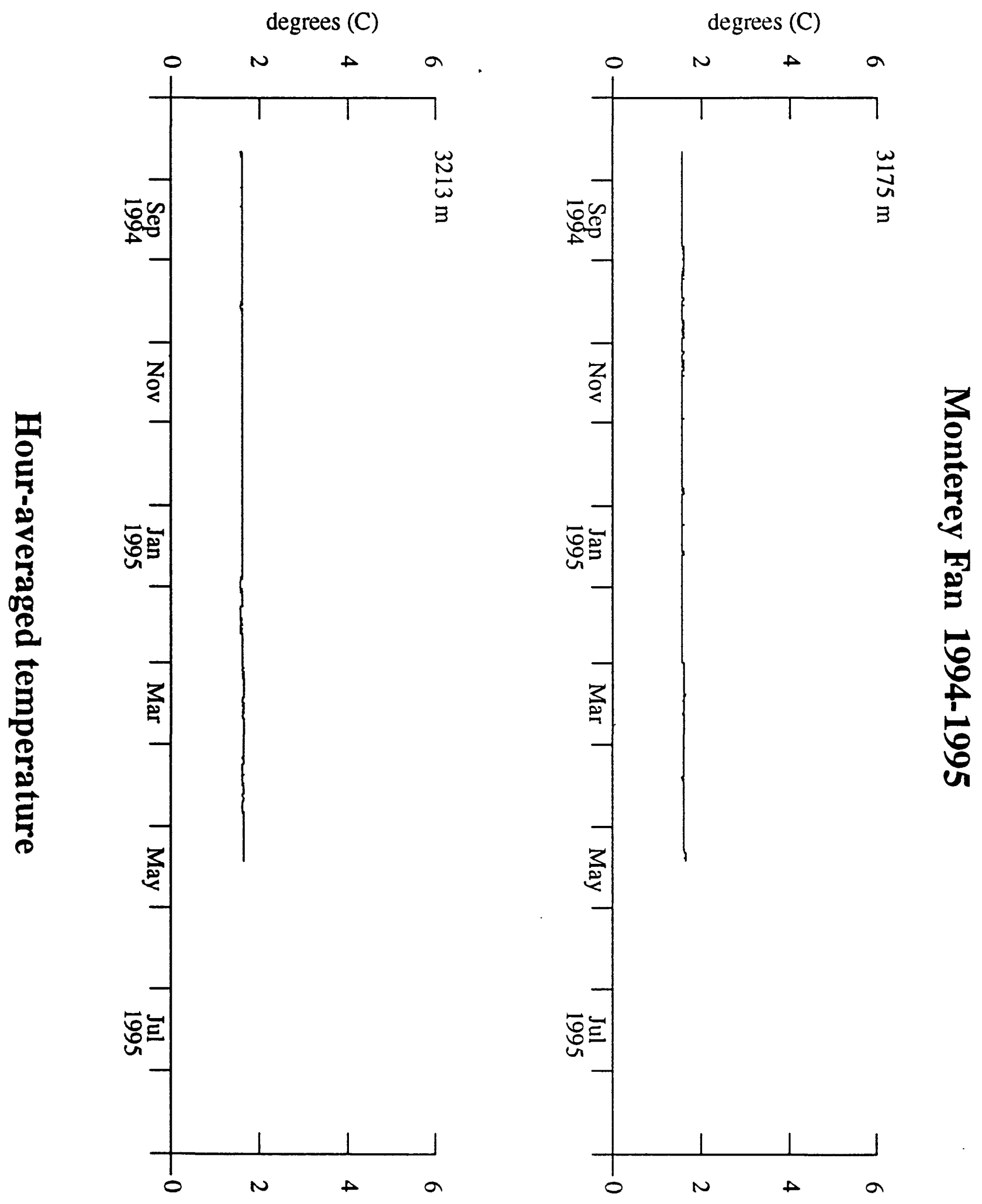


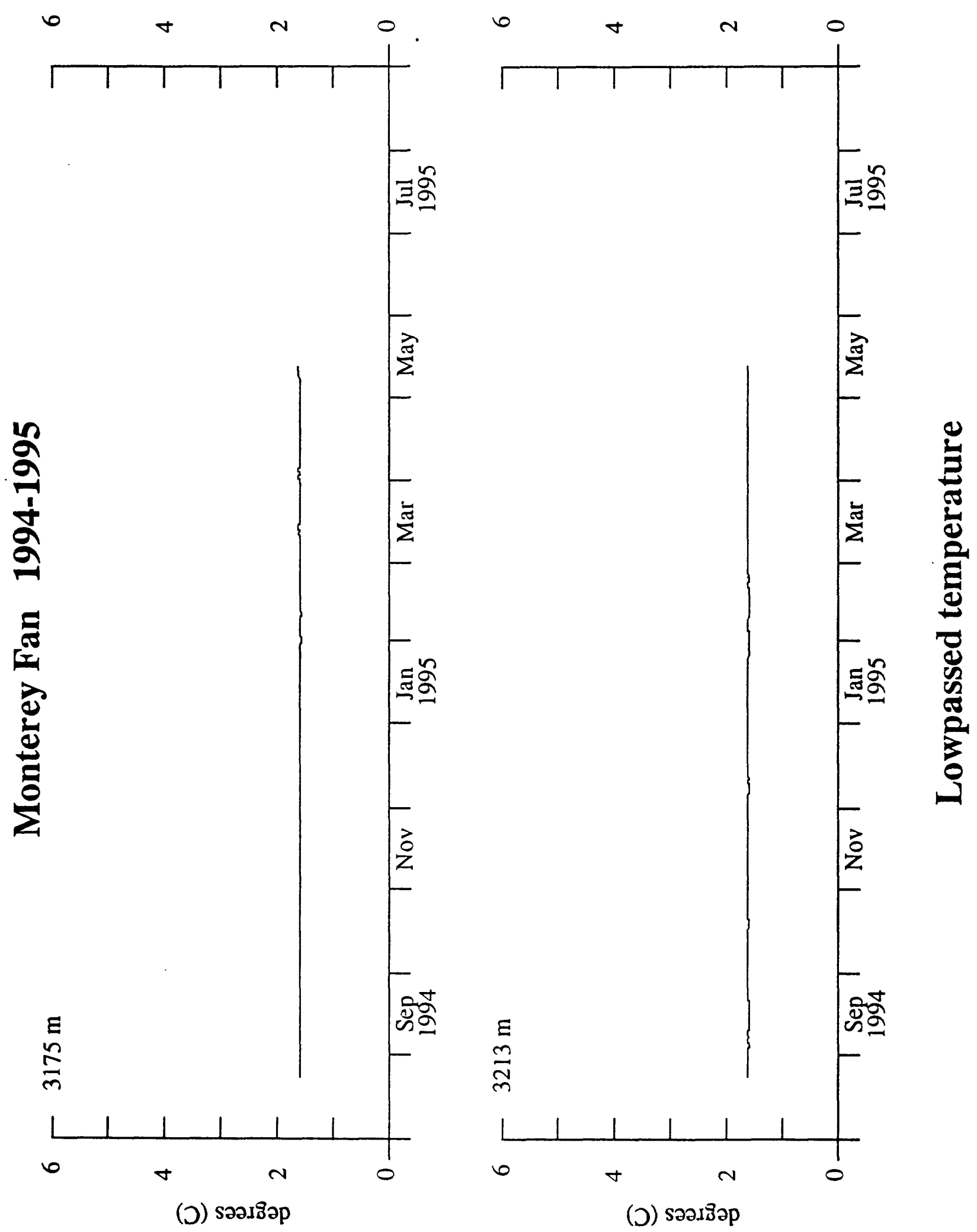




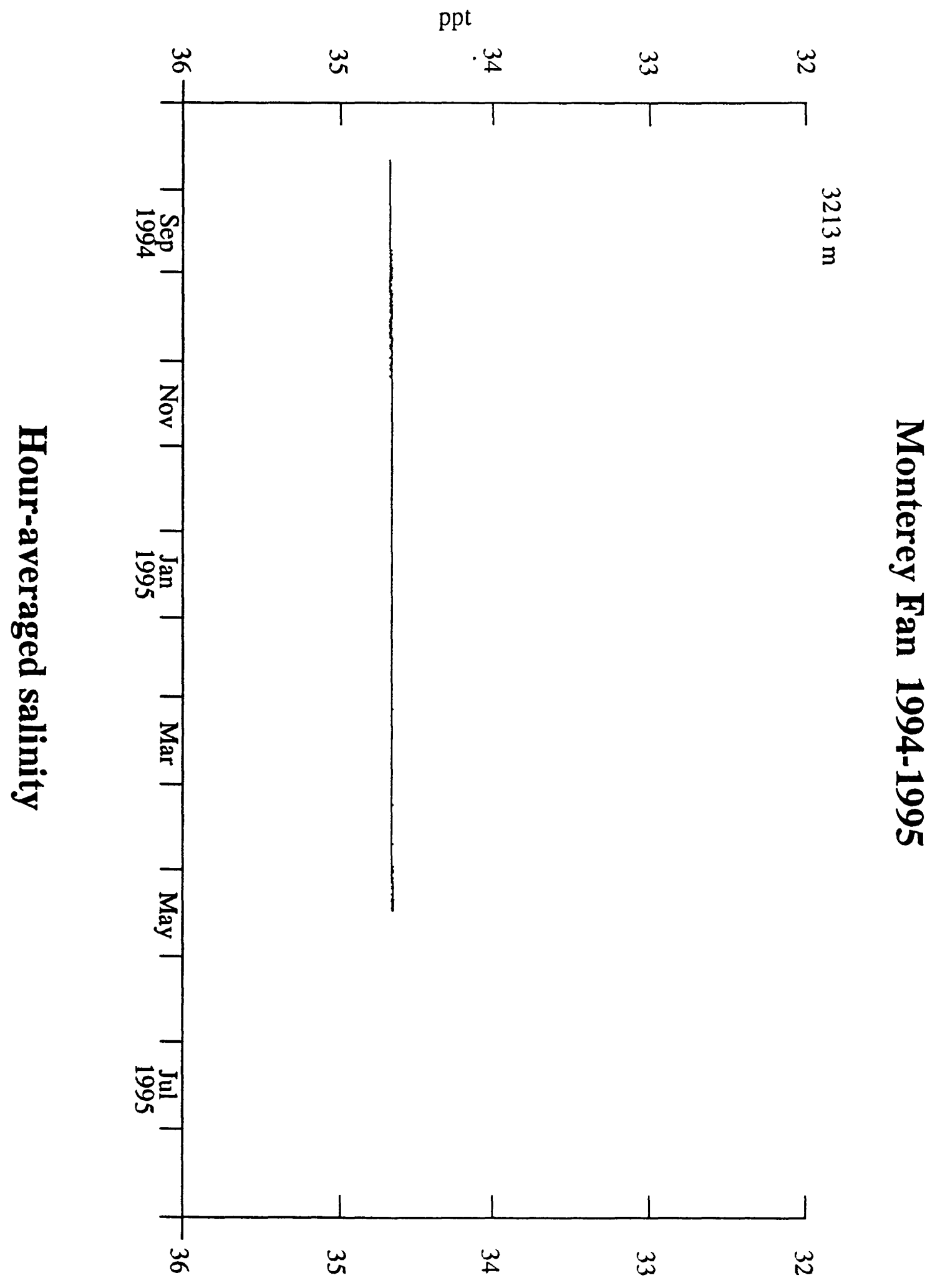

G-18 


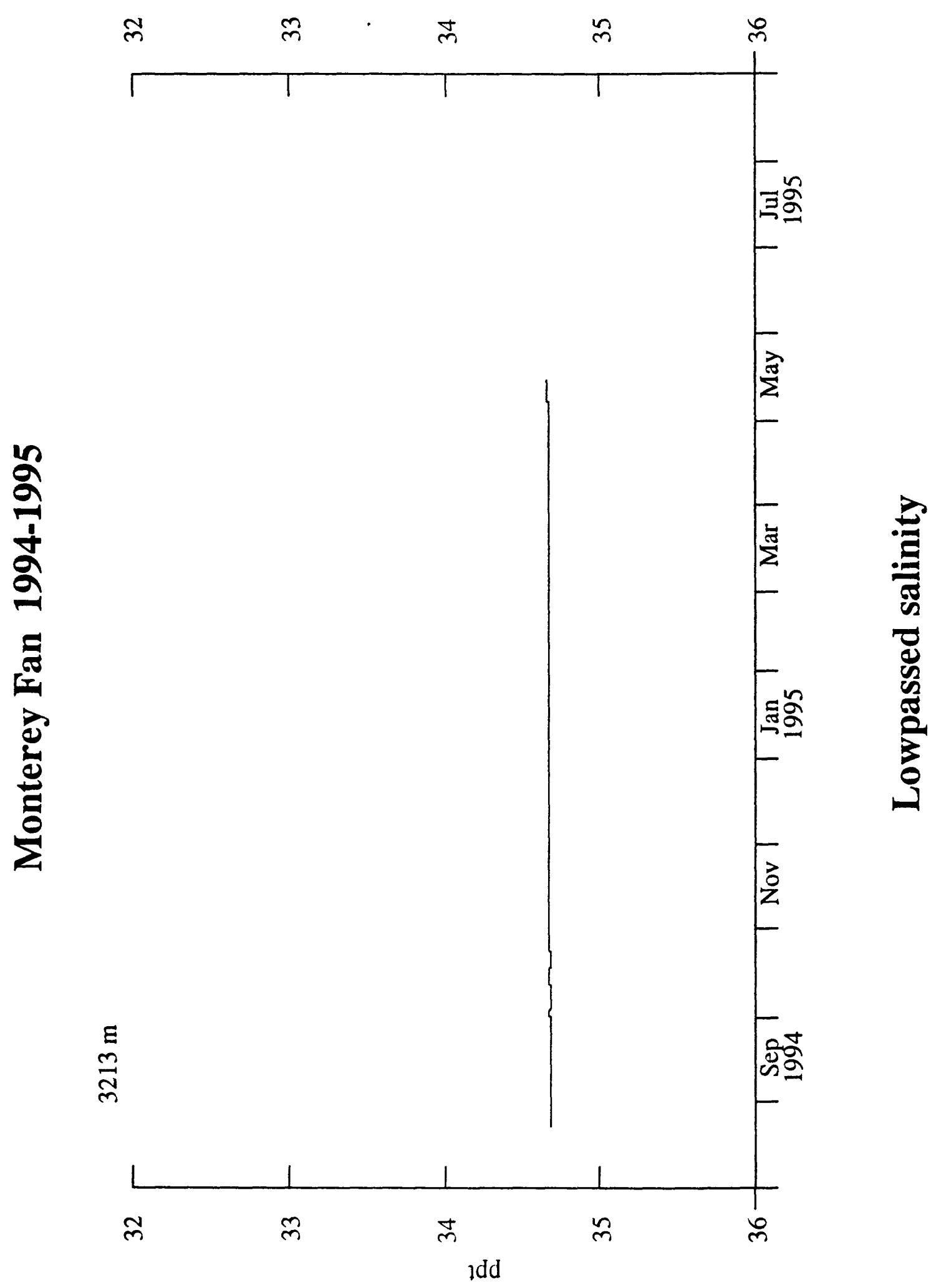

G-19 